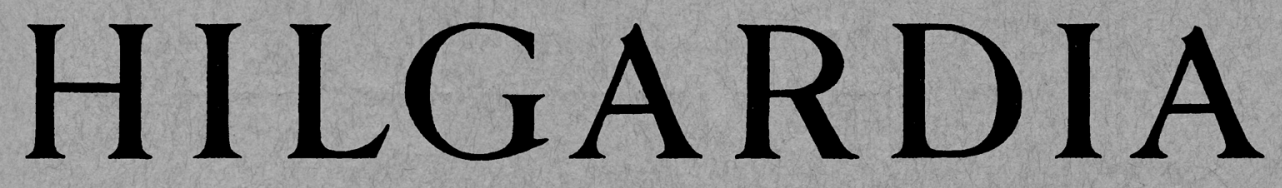

A Journal of Agricultural Science Published by the California Agricultural Experiment Station

\title{
CONTENTS
}

\section{MEASURING FOOD VALUES FOR DAIRY COWS}

MAX KLEIBER, W. M. REGAN, and S. W. MEAD 


\section{CONTENTS}

The evaluation of feeds.

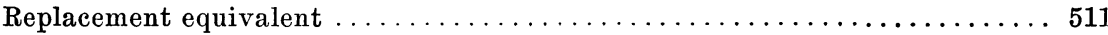

Data available at present. . . . . . . . . . . . . . 511

Critique of total digestible nutrients, net energy, and starch value as bases for evaluating dairy feeds............................. 513

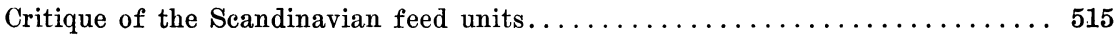

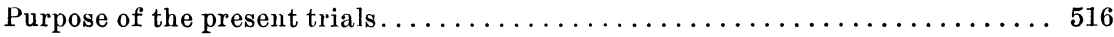

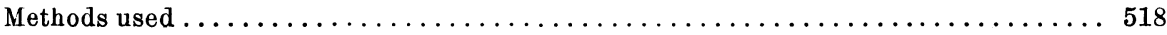

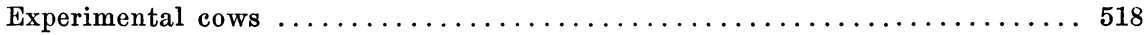

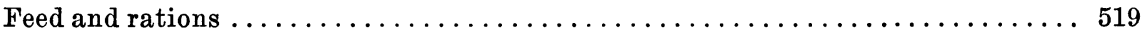

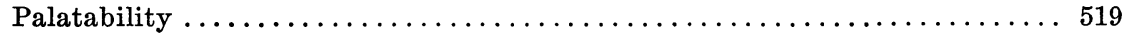

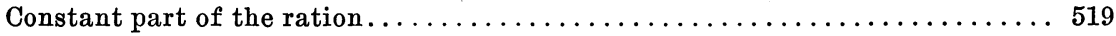

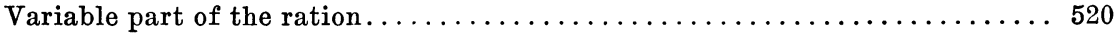

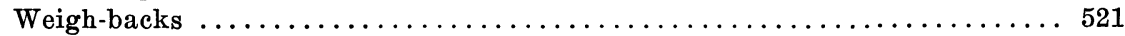

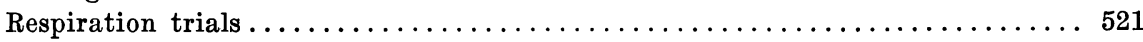

Changes in the respiration apparatus $\ldots \ldots \ldots \ldots \ldots \ldots \ldots \ldots \ldots \ldots \ldots \ldots \ldots \ldots$

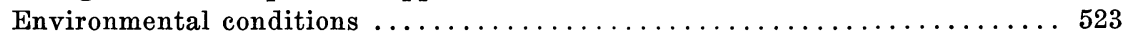

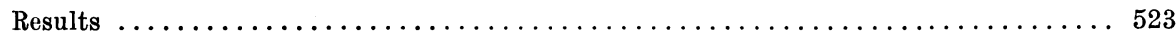

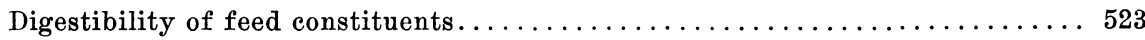

Digestibility of nitrogen and energy in Sudan hay . . . . . . . . . . 523

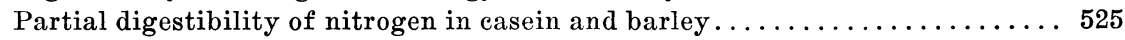

Partial digestibility of energy in glucose and barley . . . . . . . . . . 528

Methane ......................................529

Methane production and intake of Sudan hay . . . . . . . . . . . . . 529

Partial methane production resulting from reference substance. . . . . . . 530

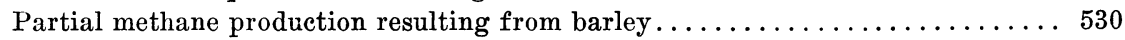

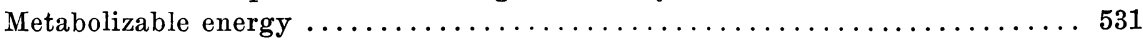

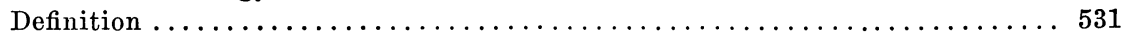

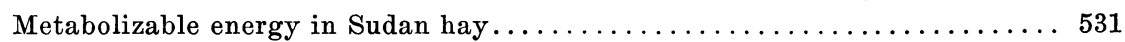

Partial metabolizable energy in reference substance...............531

Partial metabolizable energy in barley ....................533

Maintenance requirement and Sudan hay as food for maintenance........533

Definition .................................. 533

Requirement of Sudan hay for protein maintenance...............534

Requirement of Sudan hay for energy maintenance. . . . . . . . . . . 535

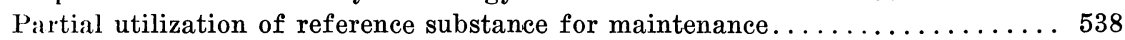

Protein and energy utilization for lactation $\ldots \ldots \ldots \ldots \ldots \ldots \ldots \ldots \ldots \ldots \ldots$

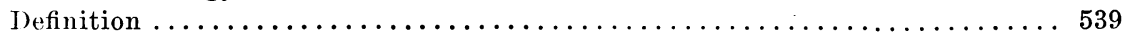

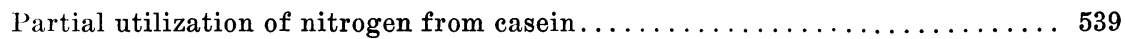

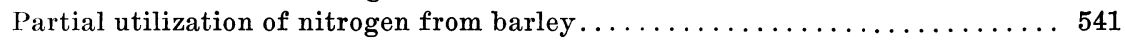

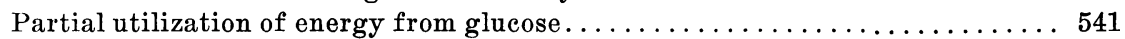

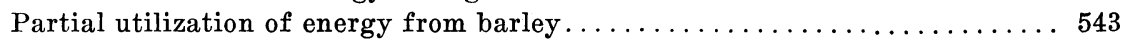

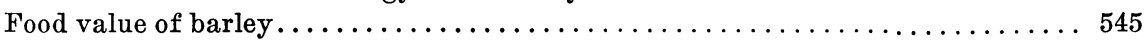

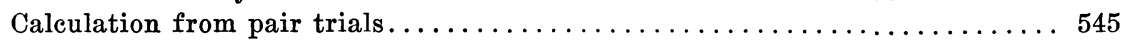

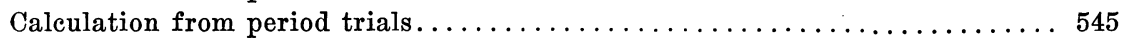

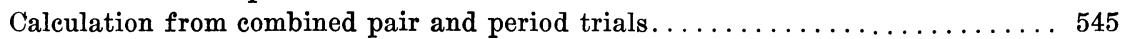

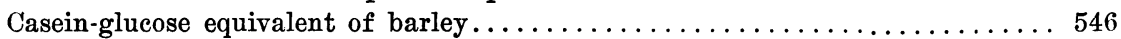

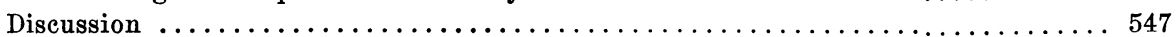

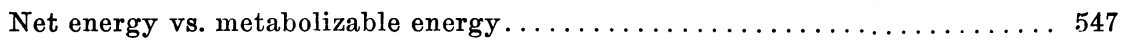

Paired respiration trials vs. Scandinavian group trials . . . . . . . . . . . 547 
Effect of basic food on reliability of results, and advantage of reference sub-

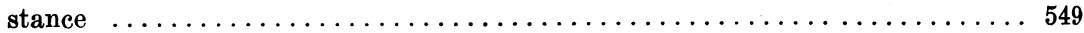

Cows vs. steers for measuring food values.................... 550

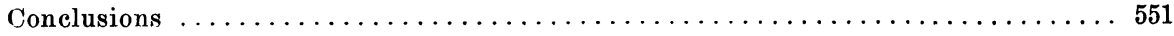

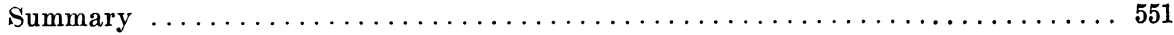

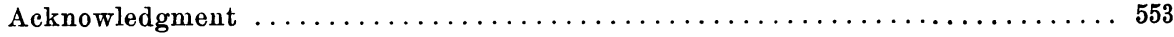

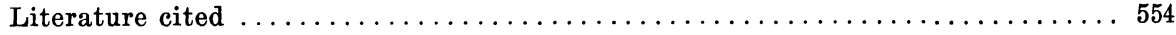

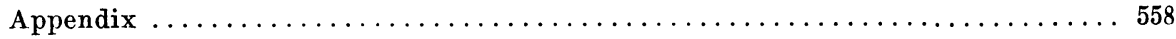

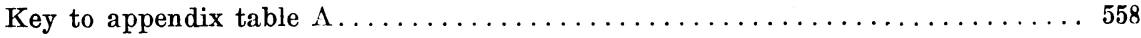

Table A : Average daily nitrogen, carbon, and energy balance........... 559

Table B: Summary of results on feed utilization................... 570

Table C: Metabolic body size for body weight of cattle $\ldots \ldots \ldots \ldots \ldots \ldots \ldots \ldots 71$ 


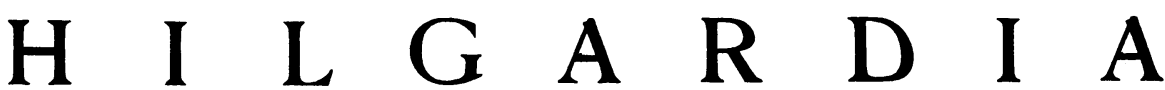

A Journal of Agricultural Science Published by

the California Agricultural Experiment Station

VoL. 16

MAY, 1945

No. 11

\section{MEASURING FOOD VALUES FOR DAIRY COW ${ }^{1,2}$}

MAX KLEIBER, ${ }^{3}$ W. M. REGAN, ${ }^{4}$ AND S. W. MEAD

\section{THE EVALUATION OF FEEDS}

FEed ACCOUNTs for over half the total cost involved in animal production (Hopkins, 1940)..$^{6}$ Obviously, then, it is important to evaluate feeds correctly.

Replacement Equivalent.-The problem can be best introduced by a simple example: If a dairy farmer can secure corn for $\$ 38$ a ton or wheat for $\$ 37$ a ton, which is the better buy?

To answer this question the farmer must know how much wheat will replace in his ration a ton of corn so that the result_-milk yield and change of body substance in the cows-will remain the same.

In this paper the figure that indicates how much of one feed is necessary to replace a certain amount of another feed is called replacement equivalent. Since, as a rule, a ration consists of several feeds, the farmer is especially interested in knowing the replacement equivalent of feeds when they form only a part of a ration. If, for example, a daily ration includes 10 pounds of hay, 1 pound of beet pulp, 1 pound of cottonseed meal, and 3 pounds of corn, how much wheat would be required to replace these 3 pounds of corn so that the new ration with wheat has the same food effect as the old ration with corn? In this case, as usually in food evaluation, only a part of the ration is replaced; and we therefore speak here of partial replacement equivalents.

Data Available at Present.--Replacement equivalents can be derived from the standard tables on total digestible nutrients : digestible protein plus digestible carbohydrates plus (2.25 $\times$ digestible fat). As Morrison (1936) shows, corn contains 83.7 pounds of total digestible nutrients per 100 pounds, and wheat 83.6. This is 94.6 pounds of total digestible nutrients per 100 pounds of dry matter for corn, 93.8 for wheat. Assuming that the offered corn and wheat, in the example cited in the preceding paragraph, have the same moisture content, the wheat is a slightly better buy : it contains 99 per cent of the total digestible nutrients of corn, and it costs only $\frac{37}{38} \times 100=97$ per cent of the
price of corn.

\footnotetext{
${ }^{1}$ Received for publication A pril 3, 1944.

2 Coöperative with United States Department of Agriculture, Bureau of Animal Industry.

${ }^{3}$ Professor of Animal Husbandry and Animal Husbandman in the Experiment Station.

- Professor of Animal Husbandry and Animal Husbandman in the Experiment Station.

- Associate Professor of Animal Husbandry and Animal Husbandman in the Experiment Station.

"See "Literature Cited" at end of the paper for complete data on citations, referred to in the text by author and date of publication.
} 
One may calculate the replacement equivalent of corn and wheat also on the basis of their net-energy content and derive from Armsby's (1922) tables a net-energy content of 95.5 "therms" per 100 pounds of dry corn and of 102.2 "therms" per 100 pounds of dry wheat. Here 100 pounds of wheat replaces 107 of corn, so that wheat at a lower price than corn is a considerably better buy. The net-energy value given in an earlier publication by Armsby and Fries (1916), based on the same data for the composition of corn (dent), is almost 5 per cent higher than that mentioned above. The discrepancy probably results from a recalculation on the basis of some different "correction." (See footnote 7, p. 513.)

A third method for calculating replacement equivalents of feeds may be based upon Kellner's (1919) tables of starch values. In the "production feed" for fattening steers, $100 \mathrm{~kg}$ of dry corn replaces $93.8 \mathrm{~kg}$ of starch; $100 \mathrm{~kg}$ of dry wheat replaces $80.5 \mathrm{~kg}$ of starch. Consequently $100 \mathrm{~kg}$ of dry wheat replaces $\frac{80.5}{93.8} \times 100=86 \mathrm{~kg}$ of dry corn. From this calculation the farmer concludes that corn at $\$ 38$ per ton is a considerably better buy than wheat at $\$ 37$ per ton-just the opposite of the conclusion based on Armsby's net energy!

Further, according to Möllgaard's (1929) table on dairy feeding, $1 \mathrm{~kg}$ corn represents 2.17 Möllgaard feed units, and $1 \mathrm{~kg}$ wheat represents 2.00 . (One Möllgaard feed unit equals 1,000 kilocalories net energy for milk production.) On the basis of these figures, $100 \mathrm{~kg}$ wheat replaces $92 \mathrm{~kg}$ corn, and corn is a better buy. The Möllgaard feed units cannot, however, be regarded as an independent type of feed evaluation: Möllgaard based his feed units, not on his own respiration trials with dairy cows, but on Kellner's respiration trials with fattening steers. The discrepancy between the replacement equivalent calculated from the Möllgaard feed units and that calculated above from Kellner's starch values therefore probably resembles the discrepancy between Armsby's net energy for corn in 1922 and that in 1916, because it probably results from different "corrections" applied to the same original data.

The Scandinavian feed units offer a fourth possible way of calculating the nutritive replacement equivalent of wheat for corn. These are replacement equivalents with $100 \mathrm{~kg}$ barley as the standard unit of reference. Thus in Nils Hansson's (1928) table, one finds that in dairy rations $100 \mathrm{~kg}$ corn can replace $105.7 \mathrm{~kg}$ barley, and $100 \mathrm{~kg}$ wheat can replace $101.1 \mathrm{~kg}$ barley. So $100 \mathrm{~kg}$ wheat

replaces $\frac{101.1}{105.7} \times 100=95.6 \mathrm{~kg}$ of corn. This comparison makes corn at $\$ 38$ a ton a slightly better buy than wheat at $\$ 37$ a ton.

According to total digestible nutrients and Armsby's net energy, wheat is a better buy ; but according to starch value and Scandinavian feed units, corn is the cheaper feed. This contradictory conclusion is based on the replacement equivalent of wheat for corn, summarized as follows for the four systems of food evaluation : according to total digestible nutrients, $100 \mathrm{~kg}$ wheat replaces $99 \mathrm{~kg}$ corn; with Armsby's net energy, $100 \mathrm{~kg}$ wheat replaces $107 \mathrm{~kg}$ corn; with Kellner's starch value, $100 \mathrm{~kg}$ wheat replaces $86 \mathrm{~kg}$ corn ; and with Scandinavian feed units, $100 \mathrm{~kg}$ wheat replaces $96 \mathrm{~kg}$ corn. 
Critique of Total Digestible Nutrients, Net Energy, and Starch Value as Bases for Evaluating Dairy Feeds.-To inquire which of these four answers is correct would be uncritical; but one may reasonably ask which is most nearly correct for the problem under discussion.

To calculate replacement equivalents on the basis of total digestible nutrients involves the assumption that 1 calorie of digestible energy in a food has the same nutritive value as 1 calorie of digestible energy in any other food-an assumption that has been challenged, at least in comparisons between roughage and concentrates. Wolff and his co-workers (1888) noticed that the digestible food energy in oats was more efficiently utilized for work of horses than the digestible food energy in hay. Schneidewind and his collaborators (1910) in their paired trials on steers also indicated that digestible food energy in corn has a greater fattening effect than digestible energy in hay.

Net energy expresses the energy which appears in the animal's products or which serves to keep the animal alive. It is the only unquestionably correct measure for the useful food energy in any one case for which it has been measured, at least if the result has not been subjected to so-called "corrections" in an attempt to make them applicable to conditions other than those of the measurements. ${ }^{7}$ How, then, could Meigs (1925) conclude that "net energy values are a less accurate measure of the relative values of feeds for maintaining uniform body weight than are total digestible nutrients"?

In his critique of net energy Meigs questioned, not the correctness of the net energy as measured directly in any one trial, but the generalization from a few results. As he showed, even with the same food, clover hay, for example, the net energy amounted to 51 per cent of the metabolizable energy in one trial, to 78 per cent in another, and to 92.7 per cent in a third trial. With such variability in the results for one single feed, measured with all possible care under well-controlled conditions, how can one expect to derive from a few trials a satisfactory mean, and even to calculate from it net-energy values for those feeds that have not been tested? Considering this great variability of the bases of Armsby's calculation, one can easily understand that in some trials, such as that of Meigs, metabolizable energy may happen to fit the results better (that is, express the true net energy of the feed under the particular conditions better) than does the net energy derived from Armsby's calculation (1922, p. 674). One is, of course, not justified in concluding, from any such single case, that Armsby's calculated net-energy values are in general less reliable measures for food values than is metabolizable energy, especially

${ }^{7}$ Calculating, for example, an animal's heat production to a standard day of 12 hours standing and 12 hours lying is an attempt to apply the results to conditions different from those under which they were obtained. Even if the energy cost of standing over lying were known satisfactorily, this ealeulation might be the opposite of what is generally understood by the term "correction." Some feeds, as Zuntz and his co-workers (1931, p. 784) report, may increase the "Bewegungstrieb" of animals and thus waste energy; others, such as alcohol, may induce the animal to lie down longer than with other feeds and thus save energy. To discover that the utilization of food energy is related to such effects of feeds on the nervous system would be of great interest; but to calculate the heat production of the animals to a standard day of 12 hours standing would eliminate rather than bring out such particular effects on food utilization. Certainly the claim would be unjustified that theoretical feed values obtained by eliminating mathematically the particular energetic effects of feeds are more correct than the feed values directly measured under the actual conditions of the experiment. 
when the latter is also merely calculated. The variability in the composition of feeds, even between feeds that are assumed to be the same, is presumably a major source of discrepancy in results. (See discussion of the tabulation on p. 520.)

Mitchell ${ }^{8}$ explains the great variability in Armsby's results by the particular experimental technique and evaluation of results followed in Armsby's earlier trials, including an exaggerated correction for standing over lying. The more recent animal-calorimeter measurements at Pennsylvania State College show a smaller variability (compare, however, footnote 22, p. 550). Mitchell (1934) himself, however, advanced the hypothesis that "except for differences in digestibility the net energy value of all perfectly balanced rations is the same under the same conditions of feeding."

Some-at least theoretical-difficulty with the strict proof of Mitchell's hypothesis is the introduction of a none-too-well-defined limiting condition: "perfectly balanced ration." If the rations to be compared need be balanced only with regard to the protein-to-energy ratio, then the problem can be readily attacked as Schneidewind and his co-workers (1910) attacked it in their experiments with steers. If, however, following Axelsson's (1939) idea, the rations must also be equally balanced with respect to the fiber content, the task becomes already rather complicated. And if we go a step further, then it becomes impossible to disprove Mitchell's hypothesis, because any deviation from the expected result could be explained by an imbalance of the rations with regard to some other, perhaps not yet known, nutritional factor.

Considering the problematic nature of a well-balanced ration, we are tempted to reverse the formulation of the hypothesis to read: "For a given production two rations are equally well balanced when the partial efficiency (or net availability, in Mitchell's terms) of the metabolizable energy for that production is equal." Instead of making a measurable quantity (efficiency) dependent on an unknown (balance of ration), this formulation defines the unknown (balance) in terms of the measurable (efficiency).

Mitchell's hypothesis would mean that differences in calorigenic action or in the partial efficiency (or net availability) of metabolizable energy are only a matter of balance of the ration. If this is generally true, then indeed feeds can be evaluated according to their content of metabolizable energy, just as Meigs (1925) proposed - a proposal apparently accepted by Kriss and Forbes in their new method of deriving a feeding standard for dairy cows (Kriss, 1931), which is a return to the system of evaluation by total digestible nutrients.

Kellner's trials $(1896,1900)$ are somewhat more suitable than Armsby's for deriving net-energy values of untested feeds : as reference substances he used semipure nutrients, especially starch, gluten, and oil, so that he could base the calculation for untested feeds on their content of digestible protein, fat, and carbohydrates, whereas Armsby disregarded the chemical composition. Much of Meigs' criticism, however, as he himself states, applies to Kellner's results as well as to Armsby's; and a later review by Axelsson (1939) reveals many defects in some of Kellner's basic work.

The comparison (made on page 512) of the replacement equivalents of wheat

${ }^{8}$ Personal communication of H. H. Mitchell with the senior author, 1943. 
for corn according to Armsby (107 kg) and according to Kellner (86 kg), both based on similar experiments with steers, is not encouraging for applying either of these systems directly in evaluating feeds for dairy cows. If this application is made, as by Möllgaard (1929), then upon the uncertainty in the list of starch values for fattening is superimposed a dubious assumptionnamely, that the relative food values are the same for functions physiologi(:ally so different as fat deposition and lactation.

Evaluation of feeds for dairy cows on the basis of Scandinavian feed units has one great advantage over the total digestible nutrients, net energy, and starch value : the Scandinavian feed units are based on trials with dairy cows. Such is not the case for those figures which were based on Hansson's (1914) "milk-starch values" assuming that 1 feed unit equals 0.75 milk-starch value. The milk-starch values of feeds are calculated from their content of digestible nutrients as in the calculation of Kellner's starch values; but for $1 \mathrm{~kg}$ digestible protein an equivalent of $1.43 \mathrm{~kg}$ starch is used instead of Kellner's 0.94 , which latter equivalent is correct only when protein is used for fat production. (Hansson's protein factor has been discussed by Kleiber, 1929.) When, however, the result of a group trial differed from the calculated "milk-starch values"-for example, from the value for wheat bran-Hansson relied on the result of the group trial.

Assuming that the feed units for wheat and corn used above are the results of Scandinavian group trials, we consider the equivalent of $96 \mathrm{~kg}$ corn for 100 $\mathrm{kg}$ wheat to be the most reliable of the four figures as a basis for estimating the relative food value for dairy cows. Yet the Scandinavian feed units themselves are open to criticism.

Critique of the Scandinavian Feed Units.-Some of the criticism against the Scandinavian feed units is based on a misunderstanding of the meaning of replacement equivalent, as shown earlier by Kleiber (1929). Two major criticisms, however, are justified :

1. In the Scandinavian group trial, body weight serves as index for body substance. The trials, especially in recent times, are so conducted that only minor changes in body weight occur. A cow can, however, maintain her body weight and yet lose body fat, because she can replace the weight of fat by the weight of water. The effect of this uncertainty on the result is not likely to be 100 per cent, as Möllgaard (1927) suggested; but it may cause considerable error.

2. Even though the exchange of barley with wheat or corn offers no essential difficulty, the replacement of barley as the reference substance by a feed rich in protein (such as cottonseed meal) leads to a change in the protein:energy ratio in the ration. Such a change in the protein:energy ratio may, however, affect the efficiency of energy utilization, as Möllgaard has shown (1923, $1929)$; his results on dairy cows have been confirmed on rats by Mitchell (1934), by Hamilton (1935), and by Forbes with his co-workers (1935). This problem has been reviewed by Mitchell (1937). Mitchell, Hamilton, and Haines (1940) found, however, no effect of inadequate protein supply (imbalance of ration) on the energy utilization of young steers. In practical group trials one may possibly keep the protein:energy ratio in a barley ration and in the corresponding ration with cottonseed meal within a range in which 
changes of this ratio have but an insignificant effect on the efficiency of energy utilization. According to Möllgaard (1931, p. 327) this range extends from a production quotient of 0.14 to 0.23 . (Möllgaard's production quotient is the ratio of protein net energy to total net energy for fattening.)

Even here, however, it is unsatisfactory to compare feeds having different protein content with one given reference substance, such as barley or starch. Protein and energy have entirely different functions in the animal body ; they "an therefore not be reduced to a single physiological basis of comparison. 'This fact has been recognized by many workers in this field; Petersen (1932) (orrectly calculates feed values from digestible energy and protein, using as a basis the prices of two standard feeds, namely cottonseed meal and corn, instead of one.

Purpose of the Present Trials.-In the experiments reported here, the aim was to investigate the possibilities of improving the evaluation of feeds. We were not encouraged by Forbes's belief (1932) that "there is no present, or possible [!] scientifically significant and defensible single measure of nutritive value of individual feeding stuffs." Obviously, however, Forbes is thinking in terms of absolute, not relative, feed values; and he does not consider the concept of partial effects, a concept very useful even when such partial effects cannot be measured directly. One can derive partial molal volumes of solutes, for example, only by measuring volumes of entire solutions ; yet physical chemists do not conclude that partial molal volumes are "insignificant" or "indefensible." Likewise, one may advantageously use partial nutritive effects even though only total food effects are (at present) directly measurable.

If a complete ration of 10 pounds of hay and 3 pounds of wheat has the same net energy as another complete ration with 10 pounds of the same hay and 2.9 pounds of corn, then the partial nutritive effect (with respect to energy) of 3.0 pounds of wheat is equal to that of 2.9 pounds of corn; or the partial replacement equivalent of 1 pound of wheat is 0.96 pound of corn. Our trials were started in the belief that to measure such partial replacement equivalents is practically possible and scientifically sound. We realize, of course, that in the measurement of partial effects in nutrition the ideal of changing only one independent variable (such as the amount or the composition of the food) to measure the corresponding partial change in the dependent variable (such as yield of nitrogen or of energy in milk) cannot be accomplished in a strict sense. When we compare the effect of a production ration fed to a lactating cow with that of a maintenance ration fed to a dry cow, not only the food has changed, but also the hormonal condition of the cow. Such hormonal changes are presumably involved in any changes of lactation rates. This unavoidable deviation of the results from ideal partial effects in a strict mathematical sense can, however, hardly lead to confusion or misinterpretation. In the comparison of corresponding partial effects of different feeds as partial replacement equivalents, the influence of these other variables on the results presumably cancels out to a considerable extent. This is one of the major advantages of using a reference substance for the measurements. (Compare p. 549.)

To meet Möllgaard's (1927) major objection against Scandinavian group trials, we measured in a respiration chamber the changes in fat and protein 
of the cow's body substance, and thus eliminated the errors involved in estimating these changes from changes in body weight. Judging from our measurements, however, the weight errors involved in a well-conducted Scandinavian group trial may be easily compensated by the larger number of cows, the longer duration of the trial, and the more "normal" conditions as compared with a pair trial in a respiration chamber.

TABLE 1

Timetable of the Main Respiration Trials

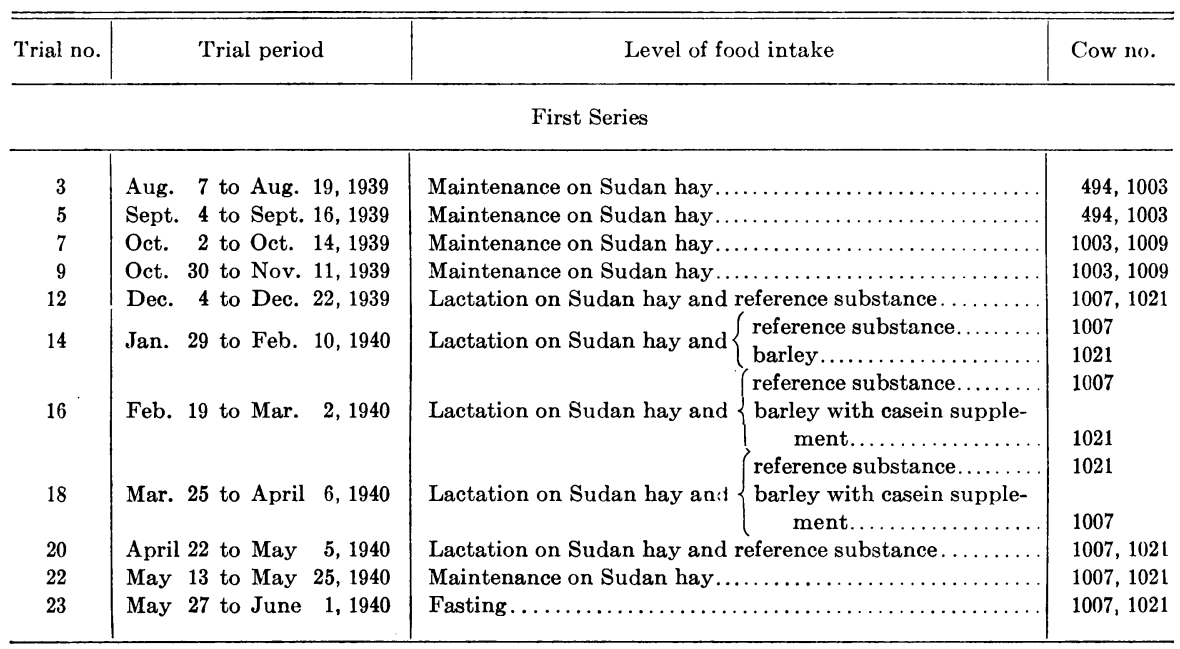

\begin{tabular}{|c|c|c|c|}
\hline \multicolumn{4}{|c|}{ Second series } \\
\hline & & $\int$ Half maintenance on Sudan hay $\ldots \ldots \ldots \ldots \ldots \ldots \ldots \ldots$ & 728 \\
\hline 24 & Jan. 27 to Feb. 15,1941 & Maintenance on Sudan hay................ & 732 \\
\hline & & Half maintenance on Sudan hay................... & 732 \\
\hline 25 & Feb. 24 to Mar. 15,1941 & Maintenance on Sudan hay $\ldots \ldots \ldots \ldots \ldots \ldots \ldots \ldots \ldots \ldots$ & 728 \\
\hline 26 & Mar. 24 to April 5,1941 & Maintenance on Sudan hay and reference substance....... & 728,732 \\
\hline 27 & April 7 to April 19, 1941 & $\begin{array}{l}\text { Maintenance on Sudan hay and reference substance......... } \\
(\text { reference substance......... }\end{array}$ & $\begin{array}{l}728,732 \\
732\end{array}$ \\
\hline 28 & June 16 to July 3,1941 & Lactation on Sudan hay and $\left\{\begin{array}{r}\text { barley with casein supple- } \\
\text { ment....................... }\end{array}\right.$ & 728 \\
\hline 29 & July 14 to Aug. 2,1941 & 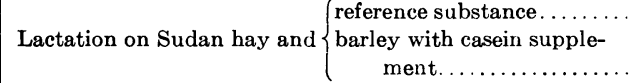 & 728 \\
\hline
\end{tabular}

More serious than the weight error in the Scandinavian group trials and their results, the feed units, is the classification of feeds with different protein content on the basis of one single reference substance-for example, barley. Such classification may lead to different protein:energy ratios in test ration and reference ration; and it neglects the fact that energy effect and protein effect are essentially and qualitatively different physiological functions. 'To overcome this difficulty we used as reference substance a variable mixture of two well-defined nutrients-namely glucose (as representative of "nitrogenfree" food energy) and casein (as representative of protein). Such a reference mixture can be adapted to any food to be tested so that the protein:energy 
ratio is exactly the same for test ration and reference ration. The reference substance for corn, for example, was composed of 10 per cent casein and 90 per cent glucose, while the reference substance for cottonseed meal consisted of 51 per cent casein and 49 per cent glucose. The simultaneous measurement of protein and energy utilization leads to a twofold result-namely the "nitrogen-free" glucose equivalent and the casein equivalent of the feed tested. This twofold result properly expresses the two essentially different physiological functions of energy and protein.

So far only trials with barley as the test feed have been carried out on dairy cows. These trials lead one to conclude that 100 grams of dry barley as part of a balanced dairy ration replaced on the average 9 grams of casein plus 100 grams of glucose.

Presumably, this casein-glucose equivalent of barley can be applied over a wider range of conditions than the absolute figures obtained in these trialsnamely, the net energy in glucose and barley and the net protein ${ }^{9}$ in casein and barley for lactation, as well as the net energy and net protein in Sudan hay for maintaining dairy cows.

Originally it was planned to measure the casein-glucose equivalent of cottonseed meal in addition to that of barley and then to suggest using a mixture of barley and cottonseed meal as an auxiliary reference substance for group trials on feed values with dairy cows. Since the lack of appetite of the cows was a major difficulty in the trials, one may expect that the more palatable auxiliary reference substance would have decided advantages over the mixture of casein and glucose even though the latter is, of course, chemically better defined.

\section{METHODS USED}

Table 1 shows the plan and timetable of the experiment. To establish the maintenance requirement, five main trials were conducted, in the first series, with Sudan hay alone while the cows were dry. Two trials (12 and 20) were carried out with both cows on the reference ration; and in three trials one cow was on the test ration while her pair-mate was on the reference ration. This series was concluded with a fasting trial of 5 days' duration. The effect of Sudan hay between the half maintenance and the maintenance level was studied in the second series. In two trials dedicated to measuring the partial effect of casein and glucose for maintenance, one cow received hay and concentrate together twice a day; the other cow, casein and glucose alone in the morning and hay alone in the evening. The last two trials were run as a combined pair and period trial to compare barley and the corresponding mixture of glucose and casein.

\section{EXPERIMENTAL COWS}

A year before the trials began, we experimented with twelve cows in order to study the palatability of various feed combinations and then to train the cows in the intake of the somewhat artificial reference diet. From these twelve animals were selected the pairs for the respiration trial. Some of their characteristics are summarized in table 2 . Their mean body weights appear in table 4 .

${ }^{9}$ Net nitrogen (a term analagous to net energy) is that part of the nitrogen in food which either appears as nitrogen of body substance or milk or eggs, or is equal to the loss of body nitrogen prevented by the food. The term "net protein" was first used by Mitchell (1922). 


\section{FEED AND RATIONS}

Palatability.-A compromise had to be reached between two aims-first, to make the ration as simple, well defined, and reproducible as possible; second, to make it reasonably palatable. For reproducibility, the ideal ration would have consisted of pure chemical substances. Obviously, however, such a ration is useless if the cows do not eat it or if they eat so little that they cannot be considered in a reasonably normal state of nutrition.

The food was composed of a basic part, kept constant throughout the tria], and a variable or replaceable part. The constant part was expected to cover

TABLE 2

ReCORD of Cows Used IN THE RESPIRATTON TRIALS

\begin{tabular}{|c|c|c|c|c|c|}
\hline \multirow{2}{*}{$\begin{array}{c}\text { Cow } \\
\text { no. }\end{array}$} & \multirow{2}{*}{ Breed } & \multirow{2}{*}{ Date of birth } & \multicolumn{2}{|c|}{$\begin{array}{l}\text { Milk record for } \\
\text { 305-day period, at age } \\
\text { of two years }\end{array}$} & \multirow{2}{*}{$\begin{array}{l}\text { Body weight range } \\
\text { during the trials } \\
\text { (kilograms) }\end{array}$} \\
\hline & & & $\begin{array}{l}\text { Milk, ex- } \\
\text { pressed in } \\
1,000 \mathrm{~kg}\end{array}$ & $\begin{array}{l}\text { Average } \\
\text { milk fat, } \\
\text { per cent }\end{array}$ & \\
\hline 494 & Jersey & May $28,1930 \ldots$ & 4.1 & 6.6 & $450-500$ \\
\hline 1003 & Holstein & Oct. 6,1934 . & 5.4 & 3.6 & $480-530$ \\
\hline 1009 & Holstein & May 6,1935 & 4.8 & 3.8 & $540-560$ \\
\hline 1007 & Holstein & Dec. $13,1934 \ldots$ & 5.2 & 3.7 & $460-480$ ( 430 at end of fast) \\
\hline 1021 & Holstein & July $22,1936 \ldots$ & 3.7 & 3.7 & $470-500$ (440 at end of fast) \\
\hline 728 & Jersey & July $\quad 4,1937 \ldots \ldots$ & 2.8 & 5.8 & $350-380$ \\
\hline 732 & Jersey & Aug. $\quad 9,1937 \ldots \ldots \ldots \ldots$ & 3.4 & 5.6 & $370-430$ \\
\hline
\end{tabular}

only the maintenance requirement; then the entire "production part," which was added to the maintenance food of the cow during lactation, could be replaced and thus used for measuring replacement equivalents.

Constant Part of the Ration.-The constant part of the ration should contain only enough protein to cover the maintenance requirement, so that all the protein required for lactation could be given in the variable part. In addition, the constant part should provide enough bulk to make the rations "normal" and palatable.

A first attempt was made to use a mixture of oat hay and molasses as the constant part of the ration; and a respiration trial was started with two cows on such a mixture as maintenance food after several weeks of training. In the respiration chambers, however, the cows began leaving more and more of this ration in the mangers. Even though the environmental conditions were kept as agreeable as possible and even though there was some feeling of herd security because the two experimental cows could see each other through a window, the confinement seemed to reduce their appetites; apparently a reliable maintenance trial could not be run in the respiration chamber on a feed that did not particularly appeal to them anyway. In seeking a more palatable feed for the basic part of the ration, Sudan hay was chosen because of its relatively low protein content; cows could be trained to eat a considerable amount of the reference food as an addition to this hay.

The Sudan grass was cut before bloom, dried in the sun, and well cured. 
The hay was then chopped and blown to a mow, from which it was taken as needed for the feeding trials.

The following tabulation gives the composition of a sample of Sudan hay:

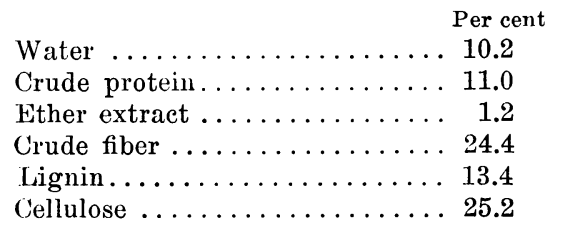

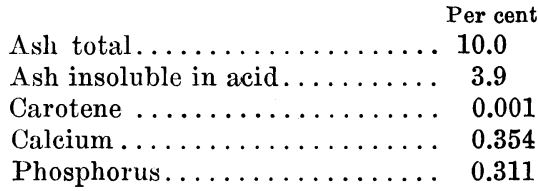

Originally it was planned to prepare pellets of ground hay as roughage for the entire trial, to insure uniformity of the constant part of the ration. This plan, which would have eliminated considerable error, unfortunately had to be abandoned because of the cost.

Table 3 shows the nitrogen, carbon, and energy content of the hay. The coefficient of variation of the nitrogen content is \pm 9 per cent for eleven samples used in the preliminary trials, and \pm 5 per cent for ten samples of hay used in the main trials. Fortunately the variability of the carbon content was smaller-namely, \pm 1.9 and \pm 1.6 per cent for the samples in preliminary and main trials respectively. The energy content varied still less : \pm 1.1 per cent and \pm 0.6 per cent for the two sets of samples.

Variable Part of the Ration.-The reference substance was composed of glucose as a standard for "nitrogen-free" food energy, and of casein as a standard food protein.

In extensive preliminary studies, the cows had apparently preferred rations containing glucose to those containing pure starch. Glucose has the further advantage of being a normal constituent of blood, whereas starch must be changed to become available to the body. The feeding of glucose instead of starch therefore meant a step forward in the simplification-in a biochemical sense-of the diet. This simplification, to be sure, may be considerably less effective in ruminants than it would be in one-stomach animals, because in cattle a considerable part of the glucose may not be absorbed into the bloodstream as such, but may be fermented by the microflora in the rumen.

Glucose was used in the form of "Cerelose." The carbon content analyzed during the first series of trials amounted to only 38.8 per cent instead of 40 . When the discrepancy was discovered, it was too late to check up on the samples used for the carbon determination. Since the product seemed rather uniform and pure, there are grounds for suspecting an error in the carbon analysis by wet combustion. The error thus possibly created amounts to 1.4 per cent of the digested carbon in trial 16. The results were calculated on the basis of the theoretical carbon content of glucose.

Since casein represents one of the major parts of cow's milk, it can be assumed to have a high biological value, especially for lactation. Again the possible changes in the rumen may reduce the importance of this point.

The casein fed was the commercial product of 80 mesh. Table 3 gives its nitrogen, carbon, and energy content in comparison with the composition of pure casein according to Hammarsten (Richmond, 1920). The major impurity of the casein used in the trials was lactose. 
In preliminary trials the cows ate the reference substance better when it was mixed with molasses beet pulp and was slightly moistened. Since poor appetite was the major difficulty, molasses beet pulp was included, and fed in about the same amount as casein. In comparing two production rations, one may count this molasses beet pulp together with the constant part of the ration. Table 3 gives the carbon, nitrogen, and energy content of the molasses beet pulp used.

The barley whose casein-glucose equivalent was measured in the trials was Western No. 1, weighing about 46 pounds to the bushel (59 kg per hectoliter). A sample contained (per 100 grams of dry matter) 5.8 grams of ash, 9.4 of protein, 1.5 of fat, 7.09 of crude fiber, and 76.3 of nitrogen-free extract.

TABLE 3

Average Nitrogen, Carbon, and Energy Contents of Feeds Used in the MaIN RESPIRATION TRIALS

\begin{tabular}{|c|c|c|c|c|}
\hline In 100 grams dry matter of & Trial series & Nitrogen & Carbon & Energy \\
\hline Sudan hay....... & 1 & $\begin{array}{c}\text { grams } \\
1.98\end{array}$ & $\begin{array}{c}\text { grams } \\
42.8\end{array}$ & $\begin{array}{c}k c a l^{*} \\
421\end{array}$ \\
\hline Sudan hay $\ldots \ldots \ldots \ldots \ldots \ldots \ldots \ldots \ldots \ldots \ldots \ldots \ldots \ldots \ldots \ldots$ & 2 & 2.24 & 43.2 & 428 \\
\hline Molasses beet pulp $\ldots \ldots \ldots \ldots \ldots \ldots \ldots \ldots \ldots \ldots \ldots \ldots \ldots$ & 1 & 1.16 & 42.7 & 403 \\
\hline 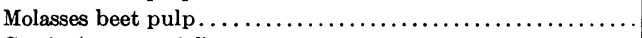 & 2 & 1.23 & 43.8 & 413 \\
\hline Casein (commercial) $\ldots \ldots \ldots \ldots \ldots \ldots \ldots \ldots \ldots$ & 1 & 13.58 & 49.7 & 545 \\
\hline Casein (commercial) ............. & 2 & 14.84 & 52.8 & 571 \\
\hline 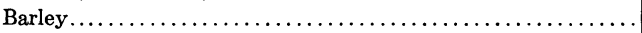 & 1 & 1.65 & 43.2 & 435 \\
\hline 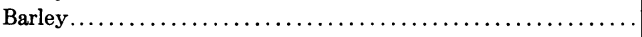 & 2 & 1.94 & 44.3 & 441 \\
\hline Casein, pure (Hammarsten)...... & .. & 15.65 & 53.0 & 586 \\
\hline Glucose, pure $\mathrm{C}_{6} \mathrm{H}_{12} \mathrm{O}_{6} \ldots \ldots \ldots \ldots \ldots \ldots \ldots \ldots \ldots \ldots \ldots$ & .. & $\ldots \ldots$ & 40.0 & 374 \\
\hline
\end{tabular}

* See footnote 11, p. 528.

To the ration was added bone meal amounting to 3 per cent and common salt amounting to 1 per cent of the dry reference substance.

Weigh-backs.-Whenever the cow left some food in the manger, these weigh-backs were collected, dried, and analyzed. In the last trial one cow left as much as 448 grams of dry matter per day. The approximate amounts of glucose, casein, and beet pulp in the weigh-back were estimated by means of chemical analysis.

Table 4 summarizes the rations ingested daily.

\section{RESPIRATION TRIALS}

Changes in the Respiration Apparatus.-The respiration apparatus used, the experimental procedure, and the method of calculating the results have been described in detail (Kleiber, 1935). Some improvements have been made. The reversing switch for moving the aspirator pipettes up and down has been replaced by an eccentric driving a rack and pinion; this made the operation quieter and more reliable. Instead of the water valves originally installed on top of the aspirator pipettes, the machine now operates with big ground-in steel stopeocks, which are greased with no. 3 cup grease mixed with graphite, and which work satisfactorily and smoothly.

To maintain a slight suction inside the chamber during the "dead period" of 
TABLE 4

Rations Consumed Daily, as DRy Matrter

\begin{tabular}{|c|c|c|c|c|c|c|c|c|}
\hline \multirow[b]{2}{*}{$\begin{array}{c}\text { Trial } \\
\text { no. }\end{array}$} & \multirow[b]{2}{*}{ Level of food intake } & \multirow[b]{2}{*}{ Cow no. } & \multirow{2}{*}{$\begin{array}{c}\text { Body } \\
\text { weight, } \\
\text { kg }\end{array}$} & \multicolumn{2}{|c|}{$\begin{array}{l}\text { Constant part } \\
\text { of ration }\end{array}$} & \multicolumn{3}{|c|}{ Variable part of ration } \\
\hline & & & & $\begin{array}{c}\text { Sudan } \\
\text { hay; } \\
\text { grams }\end{array}$ & $\begin{array}{c}\text { Molasses } \\
\text { beet } \\
\text { pulp, } \\
\text { grams }\end{array}$ & $\begin{array}{c}\text { Casein, } \\
\text { grams }\end{array}$ & $\begin{array}{c}\text { Glucose, } \\
\text { grams }\end{array}$ & $\begin{array}{l}\text { Barley, } \\
\text { grams }\end{array}$ \\
\hline
\end{tabular}

First series of trials

\begin{tabular}{|c|c|c|c|c|c|c|c|c|}
\hline & & 494 & 467 & 5,270 & $\cdots$ & $\cdots$ & $\cdots \cdots$ & $\ldots \ldots$ \\
\hline 3 & Maintenance $\ldots \ldots \ldots \ldots \ldots \ldots$ & 1003 & 493 & 5,370 & $\ldots$ & $\ldots$ & $\ldots \ldots$ & $\ldots \ldots$ \\
\hline 5 & Maintenance .............. & $\begin{array}{r}494 \\
1003\end{array}$ & $\begin{array}{l}488 \\
501\end{array}$ & $\begin{array}{l}4,455 \\
4,455\end{array}$ & $\begin{array}{l}\cdots \\
\cdots\end{array}$ & $\begin{array}{l}\cdots \\
\ldots\end{array}$ & $\begin{array}{l}\ldots \\
\ldots\end{array}$ & $\begin{array}{l}\ldots \ldots \\
\ldots\end{array}$ \\
\hline 7 & Maintenance...... & $\begin{array}{l}1009 \\
1003\end{array}$ & $\begin{array}{l}534 \\
500\end{array}$ & $\begin{array}{l}5,715 \\
5,312\end{array}$ & $\begin{array}{l}\cdots \\
\ldots\end{array}$ & $\cdots$ & $\cdots$ & $\ldots$ \\
\hline 9 & Maintenance....... & $\begin{array}{l}1009 \\
1003\end{array}$ & $\begin{array}{l}540 \\
517\end{array}$ & $\begin{array}{l}6,100 \\
5,680\end{array}$ & $\begin{array}{l}\cdots \\
\cdots\end{array}$ & $\begin{array}{l}\cdots \\
\cdots\end{array}$ & $\begin{array}{l}\cdots \\
\cdots \\
\cdots\end{array}$ & $\begin{array}{l}\cdots \\
\ldots\end{array}$ \\
\hline 12 & Lactation. . . & $\begin{array}{l}1007 \\
1021\end{array}$ & $\begin{array}{l}463 \\
474\end{array}$ & $\begin{array}{l}5,296 \\
4,883\end{array}$ & $\begin{array}{l}530 \\
530\end{array}$ & $\begin{array}{l}529 \\
529\end{array}$ & $\begin{array}{l}2,109 \\
2,109\end{array}$ & $\begin{array}{l}\ldots \\
\ldots \ldots\end{array}$ \\
\hline 14 & Lactation....... & $\begin{array}{l}1007 \\
1021\end{array}$ & $\begin{array}{l}463 \\
478\end{array}$ & $\begin{array}{l}5,236 \\
5,126\end{array}$ & $\begin{array}{l}519 \\
475\end{array}$ & $\begin{array}{c}525 \\
\ldots\end{array}$ & $\begin{array}{c}2,109 \\
\ldots \ldots\end{array}$ & $\ddot{3,281}$ \\
\hline 16 & Lactation. & $\begin{array}{l}1007 \\
1021\end{array}$ & $\begin{array}{l}460 \\
473\end{array}$ & $\begin{array}{l}5,258 \\
5,258\end{array}$ & $\begin{array}{l}519 \\
475\end{array}$ & $\begin{array}{l}521 \\
318\end{array}$ & $\begin{array}{c}2,110 \\
\ldots \ldots\end{array}$ & $\ddot{3}, 118$ \\
\hline 18 & Lactation. & $\begin{array}{l}1007 \\
1021\end{array}$ & $\begin{array}{l}470 \\
473\end{array}$ & $\begin{array}{l}5,219 \\
5,219\end{array}$ & $\begin{array}{l}386 \\
386\end{array}$ & $\begin{array}{l}241 \\
402\end{array}$ & $\begin{array}{l}\ldots \\
1,646\end{array}$ & $\begin{array}{l}2,39 ; \\
\ldots \ldots\end{array}$ \\
\hline 20 & Lactation. . & $\begin{array}{l}1007 \\
1021\end{array}$ & $\begin{array}{l}464 \\
473\end{array}$ & $\begin{array}{l}5,274 \\
5,274\end{array}$ & $\begin{array}{l}395 \\
395\end{array}$ & $\begin{array}{l}402 \\
402\end{array}$ & $\begin{array}{l}1,646 \\
1,646\end{array}$ & $\begin{array}{l}\ldots \ldots \\
\ldots \ldots\end{array}$ \\
\hline 22 & Maintenance............. & $\begin{array}{l}1007 \\
1021\end{array}$ & $\begin{array}{l}457 \\
466\end{array}$ & $\begin{array}{l}5,318 \\
5,318\end{array}$ & $\begin{array}{l}\cdots \\
\cdots\end{array}$ & $\begin{array}{l}\ldots \\
\cdots\end{array}$ & $\ldots$ & $\begin{array}{l}\ldots \\
\ldots \ldots\end{array}$ \\
\hline \multicolumn{9}{|c|}{ Second series of trials } \\
\hline 24 & Maintenance....... & $\begin{array}{l}732 \\
728\end{array}$ & $\begin{array}{l}409 \\
372\end{array}$ & $\begin{array}{l}4,257 \\
2,151\end{array}$ & $\cdots$ & $\cdots$ & $\cdots$ & $\cdots$ \\
\hline 25 & Maintenance.... & $\begin{array}{l}732 \\
728\end{array}$ & $\begin{array}{l}432 \\
371\end{array}$ & $\begin{array}{l}2,186 \\
3,243\end{array}$ & $\begin{array}{l}\cdots \\
\cdots\end{array}$ & $\begin{array}{l}\cdots \\
\cdots\end{array}$ & $\cdots$ & $\cdots$ \\
\hline 26 & Maintenance............... & $\begin{array}{l}732 \\
728\end{array}$ & $\begin{array}{l}434 \\
380\end{array}$ & $\begin{array}{l}2,186 \\
2,186\end{array}$ & $\begin{array}{l}\cdots \\
\cdots\end{array}$ & $\begin{array}{l}144 \\
144\end{array}$ & $\begin{array}{l}1,107 \\
1,107\end{array}$ & $\ldots$ \\
\hline 27 & Maintenance........ & $\begin{array}{l}732 \\
728\end{array}$ & $\begin{array}{l}430 \\
382\end{array}$ & $\begin{array}{l}2,186 \\
2,186\end{array}$ & $\begin{array}{l}\cdots \\
\cdots\end{array}$ & $\begin{array}{l}144 \\
144\end{array}$ & $\begin{array}{l}1,107 \\
1,107\end{array}$ & $\begin{array}{l}\ldots \\
\ldots \\
\ldots\end{array}$ \\
\hline 28 & Lactation . . . . . . . . . . . . & $\begin{array}{l}732 \\
728\end{array}$ & $\begin{array}{l}378 \\
347\end{array}$ & $\begin{array}{l}3,580 \\
3,580\end{array}$ & $\begin{array}{l}400 \\
400\end{array}$ & $\begin{array}{r}376 \\
90\end{array}$ & $\begin{array}{l}3,232 \\
\ldots \ldots\end{array}$ & $\ddot{4}, 183$ \\
\hline 29 & Lactation. .............. & $\begin{array}{l}732 \\
728\end{array}$ & $\begin{array}{l}373 \\
347\end{array}$ & $\begin{array}{l}3,580 \\
3,580\end{array}$ & $\begin{array}{l}400 \\
327\end{array}$ & $\begin{array}{r}90 \\
308\end{array}$ & 2,981 & $\begin{array}{l}4,183 \\
\ldots \ldots\end{array}$ \\
\hline
\end{tabular}


the aspirator, there was installed on top of each chamber a bellows made of an automobile inner tube slit open lengthwise and connected to the top of the chamber and to a circular sheet of aluminum. The center of this sheet is connected to a steel spring, which in turn is suspended from the ceiling of the room. The spring is made of steel wire, $2 \mathrm{~mm}$ thick, wound to a diameter of $2.5 \mathrm{~cm}$; and a length of $1 \mathrm{~m}$ (in unstretched condition) is used for each bellows. A load of $1 \mathrm{~kg}$ stretches the spring $31 \mathrm{~cm}$. When the aspirator sucks air out of the chamber, the metal plate of the bellows is drawn down to the roof of the chamber, since the inside of the bellows is connected to the inside of the chamber. When the aspirator reaches its dead period and there is no suction, the spring draws the metal sheet away from the chamber, thus drawing air from the chamber to the bellows. According to a test with a sensitive diaphragm manometer connected to a kymograph, this action of the bellows prevents a complete loss of suction in the chamber during the dead period of the aspirator.

The mercury in the sampling device becomes rapidly contaminated, probably with sulfide, when it pumps moist air that comes from the animal chamber. This trouble is almost completely avoided when the air is dried before coming in contact with the mercury. To eliminate weekly cleaning of the mercury in the sampling device, the air sample is dried before it reaches the mercury pump. Necessarily, however, this drying introduces considerable dead space. To avoid the resultant errors, the aspirator now pumps for every cycle (500 liters of ventilation air) a sample of 1 liter through a drier with phosphorus pentoxide and then back to the air line. From this sample of the first order, the mercury pump takes the secondary or actually used sample of $20 \mathrm{ml}$ per cycle for the absorption battery and of $0.5 \mathrm{ml}$ per cycle for the collector of the composite sample, which is later analyzed in a Haldane apparatus modified by Kleiber (1933) and mechanized by Winchester (1938).

Environmental Conditions.-The chambers were kept at about $20^{\circ} \mathrm{C}$ and at a relative humidity of 60 per cent.

\section{RESULTS}

\section{DIGESTIBIIITY OF FEED CONSTITUENTS}

Digestibility of Nitrogen and Energy in Sudan Hay.-The digestibility as used here is the quotient $\frac{\text { food minus feces }}{\text { food }} \times 100$. This is often called "apparent

digestibility" because part of the substance excreted in the feces is not undigested residues of the ingested food, but is material that has passed the metabolic process of the animals and is excreted into the intestinal tract.

In the first series, the digestibility was measured during the preliminary period of each experiment in order to check upon the results of the relatively short periods. On the average, the digestion coefficients in preliminary trials were equal to those of the main periods (table 5).

Statistically the slight decrease of the digestibility in the second series $(61.7 \pm 1.0)$ compared with that in the first $(62.5 \pm 0.9)$ is insignificant. The mean digestibility of nitrogen in Sudan hay for fourteen main trials on 
maintenance is $61.9 \pm 1.8$ per cent. The digestibility of energy seems considerably higher for the Sudan hay used in these trials than the quotient total digestible nutrients total nutrients

$1936)$ amounts to 55 per cent. In our trials, the digestion coefficient for energy in Sudan hay was $67.8 \pm 0.3$ and $66.2 \pm 0.9$ per cent, first and second series

TABLE 5

Digestibility of Nitrogen aNd ENERgy iN SUdAN HAY

\begin{tabular}{|c|c|c|c|}
\hline \multirow[b]{2}{*}{ Experiments } & \multirow{2}{*}{$\begin{array}{c}\text { Number } \\
\text { of } \\
\text { determi- } \\
\text { nations }\end{array}$} & \multicolumn{2}{|c|}{ Average digestibility } \\
\hline & & Nitrogen & Energy \\
\hline First series, preliminary respiration trials. . & 10 & $\begin{array}{c}\text { per cent } \\
62.1 \pm 1.5\end{array}$ & $\begin{array}{c}\text { per cent } \\
67.7 \pm 0.5\end{array}$ \\
\hline First series, main respiration trials........ & 10 & $62.5 \pm 0.9$ & $67.8 \pm 0.3$ \\
\hline 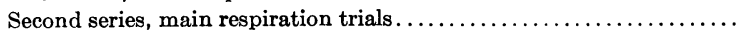 & 4 & $61.7 \pm 1.0$ & $66.2 \pm 0.9$ \\
\hline
\end{tabular}

TABLE 6

Total and Partial Digestibility of Energy in Sudan Hay

\begin{tabular}{|c|c|c|c|c|c|c|c|}
\hline \multirow[b]{2}{*}{ Cow no. } & \multirow[b]{2}{*}{ Trial no. } & \multicolumn{3}{|c|}{ Total digestibility } & \multicolumn{3}{|c|}{ Partial digestibility } \\
\hline & & $\begin{array}{c}\text { Food } \\
\text { energy } \\
\text { consumed } \\
\text { per day }\end{array}$ & $\begin{array}{l}\text { Energy } \\
\text { digested } \\
\text { per day }\end{array}$ & $\begin{array}{c}\text { Digesti- } \\
\text { bility }\end{array}$ & $\begin{array}{l}\text { Change in } \\
\text { food energy } \\
\text { consumed } \\
\text { per day }\end{array}$ & $\begin{array}{l}\text { Change in } \\
\text { energy } \\
\text { digested } \\
\text { per day }\end{array}$ & $\underset{\text { digestibility }}{\text { Partial }}$ \\
\hline & & $k c a l^{*}$ & $k c a l$ & per cent & $k c a l$ & $k c a l$ & per cent \\
\hline 728 & $\begin{array}{l}24 \ldots \ldots \ldots \ldots \ldots \ldots \\
25 \ldots \ldots \ldots \ldots \ldots\end{array}$ & $\begin{array}{r}9,290 \\
13,982\end{array}$ & $\begin{array}{l}6,288 \\
9,006\end{array}$ & $\left.\begin{array}{l}67.7 \\
64.4\end{array}\right\}$ & 4,692 & 2,718 & 57.9 \\
\hline 732 & $\begin{array}{l}25 \ldots \ldots \ldots \ldots \\
24 \ldots \ldots \ldots \ldots\end{array}$ & $\begin{array}{r}9,393 \\
18,418\end{array}$ & $\begin{array}{r}6,152 \\
12,356\end{array}$ & $\left.\begin{array}{l}65.5 \\
67.1\end{array}\right\}$ & 9,025 & 6,204 & 68.7 \\
\hline
\end{tabular}

- See footnote 11, p. 528.

respectively, or $67.2 \pm 0.4$ per cent for all fourteen main trials, when the results are statistically weighted for the duration of the trials.

In the second series, two trials were conducted to compare the utilization of Sudan hay fed at the half maintenance and at the maintenance level. Table 6 shows the digestion coefficients for energy that resulted from these trials; it serves especially to illustrate the meaning and the calculation of partial in contrast to total digestibility.

The term partial digestibility is chosen somewhat in analogy to the terminology used in basic sciences. The term "partial quantity," to be sure, is reserved in chemistry (Lewis and Randall, 1923, p. 34) for partial differential quotients, whereas quotients of partial differences are called apparent quantities. "Apparent" is, however, a rather poor adjective in this connection, because what "appears" is always a total, not a partial, effect (though partial effects may in special cases closely approach total effects). Aside from this criticism of "apparent," the term "apparent digestibility" is already used in 
the literature. All the digestibility figures in the present paper are results for apparent digestibility (as distinguished from the "true" digestibility obtained by subtracting the metabolic nitrogen from the total nitrogen in the feces). The term apparent digestibility can therefore not be used to distinguish the quotient $\frac{\Delta \text { digested }}{\Delta \text { food }}$ from $\frac{\text { digested }}{\text { food }}$

When at some future time the relation of digestibility to level of food intake is known accurately enough, one may have to call $\frac{\Delta \text { digested }}{\Delta \text { food }}$ the "mean partial digestibility" over a given range of food intake, in order to reserve "partial digestibility" for the partial differential quotient $\frac{\delta \text { digested }}{\delta \text { food }}$

Partial Digestibility of Nitrogen in Casein and Barley.-The following example (based on trial 16, cow 1007) shows how the partial digestibility of protein in casein was calculated:

\section{Sample Calculation 1: Partial Digestibility of Nitrogen in Casein}

1. Total nitrogen digested per day:

193 grams nitrogen in feed minus 74 grams nitrogen in feces........119 grams $^{10}$

2. Partition of nitrogen digested per day:

Nitrogen digested from Sudan hay per day: 117 grams nitrogen in Sudan hay with a digestibility of 58 per cent (resulting from trials 21 and 22 , cows 1007 and 1021) . 68 grams

Nitrogen digested from molasses beet pulp per day: 6 grams nitrogen with 62 per cent digestibility (as given in Morrison's 1936 tables) $\ldots \ldots \ldots \ldots \ldots \ldots \ldots \ldots 4$ grams

Nitrogen digested from hay and beet pulp: $68+4 \ldots \ldots \ldots \ldots \ldots \ldots \ldots \ldots \ldots$ grams

Nitrogen digested from easein per day: $119-72 \ldots \ldots \ldots \ldots \ldots \ldots \ldots$ grams

3. Partial digestibility of nitrogen from casein:

Nitrogen consumed in easein per day ................... 70 grams

Partial digestibility of nitrogen from easein $: \frac{47}{70} \times 100 \ldots \ldots \ldots \ldots \ldots 67$ per cent

In the first series, the partial digestibility of casein was $71 \pm 1.5$ per cent for cow 1007 (trials 12, 14, 16, and 20) and $72 \pm 0$ for cow 1021 (trials 12, 18 , and 20). In the second series it was much more variable and lowernamely, 51 per cent for cow 732 in trial 28 and only 36 per cent for cow 728 in trial 29. During maintenance trials the partial digestibility of casein was highly variable - as might be expected, since the amounts fed (21.49 grams nitrogen in casein per day) were less than one half of those fed during the production trials. When casein and glucose were fed alone in the morning and Sudan hay alone in the evening, the partial digestibility of casein nitrogen was 56 per cent for cow 728 (trial 27) and as high as 71 per cent for cow 732 (trial 26).

The mean of the partial digestibility of nitrogen in casein in the nine lactation trials of both series is $65.2 \pm 4.3$ per cent.

\footnotetext{
${ }^{10}$ In the sample calculations, figures in bold-faced type represent major results. Figures in ordinary type represent intermediate calculations.
} 
The partial digestibility of nitrogen from barley was 67, 88, and 74 per cent for the first series. The low value of 67 resulted, in trial 14, with the low protein content of the ration having no casein supplement. During the second series of trials, the partial digestibility of nitrogen in casein was 67 and 64 per cent for cows 732 and 728 respectively. The mean of the partial digestibility of nitrogen in barley in five lactation trials is $72 \pm 4.3$ per cent. According to Watson and his co-workers (1939), the partial digestibility of nitrogen in barley, fed together with timothy hay, is 75.1 per cent. (Morrison, 1936, gives for eastern barley a protein digestibility of 79 per cent.) The difference between the nitrogen digestibility in casein and barley is not statistically significant.

According to Mendel and Fine (1912), meat did not increase the fecal nitrogen excretion of dogs over that resulting from a nitrogen-free diet, an observation confirmed by Mitchell and Carman (1924) on the rat with egg and pork added to a nitrogen-free diet. That in the cows casein should be no more digestible than barley protein may therefore seem surprising.

One may assume that the nitrogen from casein is actually fully digestible, and regard the low partial nitrogen digestibility of the rations with the reference substance as the result of a depression of the apparent nitrogen digestion by glucose. That carbohydrates depress the digestibility of protein was indeed suggested as early as 1870 by Stohmann (Mayer, 1925), who gave a formula to calculate the apparent digestibility of protein as a function of the carbohydrate content of the ration. G. Kühn (Kellner, 1919, p. 53) observed that starch decreased the digestibility of hay protein from 57 to 49 per cent when $1.67 \mathrm{~kg}$ of starch was added, and to 42 per cent when $2.87 \mathrm{~kg}$ of starch was added, to the same amount of hay. Armsby (1922, p. 618) concludes from Pfeiffer's and Kellner's data that "the digestion of each 100 grams of dry matter, whether protein or nitrogen-free material, results in the excretion in the feces of approximately 0.4 gram of nitrogen in the form of excretory products," which products he regards (p. 109) as composed of "unresorbed digestive juices and their decomposition products, intestinal mucus, worn-out epithelial cells and cell fragments, leucocytes and excretions of the intestinal mucosa." An increase of this intestinal excretion, according to Armsby, causes the depression of the apparent nitrogen digestibility by carbohydrate feeding.

The nitrogen in these excretory products was later designated as metabolic nitrogen. Mitchell (1926, p. 34), on the basis of experiments of Morgan, Berger, and Westhauser on sheep, assumes that the excretion of metabolic nitrogen, per 100 grams of dry matter consumed, amounts to 0.5 gram when the rations contain considerable amounts of crude fiber. "It seems," writes Mitchell, "that the differences in apparent digestibility observed may be explained entirely on the demonstrated property of carbonaceous food of causing an excretion of metabolic nitrogen in the feces in proportion to its dry matter content."

Hamilton (1942, p. 107) noted, in trials with sheep, that glucose, added in amounts of 20 to 30 per cent to a ration of timothy hay, yellow corn, and cottonseed meal, reduced the digestibility of nitrogen from 62 to 54 per cent. This depression of nitrogen digestibility can be accounted for, according to 
Hamilton, by an estimated increase in the metabolic nitrogen in the feces of the sheep on the sugar ration.

The concept of metabolic nitrogen, however, does not seem to be sufficiently clear yet as a basis for a satisfactory explanation. On page 21 Mitchell (1926) states that "a certain fraction of the fecal nitrogen, the so-called 'metabolic nitrogen' of the feces, is contained in substances originating in the animal body." On page 27 he includes in the metabolic nitrogen of the feces also the "waste nitrogen from digestion," in addition to the waste nitrogen from the body. On page 29 he writes: "It appears, therefore, that the so-called "metabolic' nitrogen of the feces consists predominantly of nitrogenous waste products of digestion rather than metabolism."

Why a soluble nitrogen-free substance increases nitrogenous waste products of digestion, is a problem that needs further clarification.

Aside from nitrogen digestibility, the addition of glucose distinctly depressed also the digestibility of crude fiber in steer calves (Mitchell, Hamilton, and Haines, 1940) and in sheep (Hamilton, 1942). An explanation of the depression of nitrogen digestibility in ruminants may be attempted on the basis of these observations. If less fiber is digested with the added sugar, presumably more food protein remains protected by fiber against the action of digestive enzymes and absorption through the intestinal tract. In this case, however, the depression would involve the "true" digestibility; unabsorbed food nitrogen, rather than metabolic nitrogen, should be increased in the feces. One does not have to assume with Hamilton that rumen bacteria (like people) "prefer" sugar to fiber; sugar may, to the contrary, have an adverse effect on the rumen flora, or at least on that part of this flora which attacks fiber. Any reduction of bacterial activity could account for decreased fiber digestion. $\Lambda$ suitable antiseptic in the rumen would probably lead to a decrease in fiber ligestion. Following his reasoning in the Journal of Nutrition (based solely on digestion data), Hamilton would then have to conclude that bacteria which, in the absence of the bactericide, attack cellulose will prefer the bactericide to the fiber.

Woodman and Evans (1938) have demonstrated that rumen bacteria in vitro ferment glucose readily. Possibly the split products of glucose resulting from this fermentation inhibit or at least depress the fermentation of fiber. An increase in fecal nitrogen may of course also result from an increase in bacterial growth possibly favored by sugar and leading to an increase in bacterial protein in the feces.

The depression of the apparent digestibility of protein by carbohydrates is not yet satisfactorily explained. Our trials do not lead to the solution of this problem either. We therefore simply report the results as partial effects, reserving possible explanations to later investigations. .

The partial digestibility of the nitrogen in the casein, namely 72 per cent for the first series of the trials, indicates that the fecal nitrogen was increased 0.28 gram for each gram of nitrogen in casein. The reference substance contained 25 grams casein or 3.4 grams nitrogen per 125 grams of dry reference substance or per 100 grams glucose. The partial fecal nitrogen resulting from the reference substance thus amounts to $3.4 \times \frac{100}{125} \times 0.28=0.78$ gram nitrogen 
per 100 grams of dry reference substance or to $3.4 \times 0.28=0.95$ gram nitrogen per 100 grams of glucose. This is about twice the effect observed in the earlier trials reported above. For the second series, with only two results and much more variability, the depression is still greater.

Partial Digestibility of Energy in Glucose and Barley.-Sample calculation 2 (based on trial 16, cow 1007) shows how the partial digestibility of energy from glucose was calculated. The mean for this partial digestibility, calculated from seven main production trials, is $83 \pm 1$ per cent. This partial digestibility was higher in the second series-89 and 88 per cent, respectively, for cows 732 and 728. Still somewhat higher, but not significantly different from the last results, are those from maintenance trials in the second series, with a mean for four trials of $93.5 \pm 3.4$ per cent.

Sample Calculation 2 : Partial Digestibility of Einergy in Giudcose

1. Total energy digested per day:

Energy in feed per day $\ldots \ldots \ldots \ldots \ldots \ldots \ldots \ldots \ldots \ldots \ldots \ldots \ldots \ldots \ldots \ldots \mathrm{keal}^{11}$

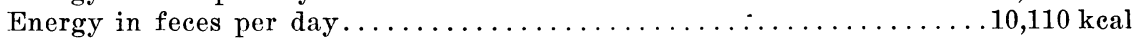

Digested energy per day $(35,150-10,110) \ldots \ldots \ldots \ldots \ldots \ldots \ldots \ldots \ldots$ kcal

2. Partition of energy digested per day:

Energy digested from Sudan hay per day: Energy consumed per day in 5,258 grams dry Sudan hay is $22,320 \mathrm{keal}$. The digestibility of this energy for cows 1007 and 1021, trials 21 and 22 , averages 66.2 per cent; therefore the energy digested from hay is

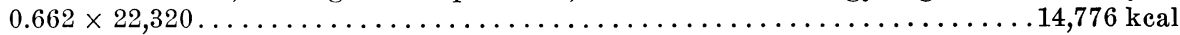

Energy digested from molasses beet pulp per day: Energy consumed per day in 519 grams dry molasses beet pulp is 2,095 keal; digestibility (according to Morrison's 1936 tables) is 85 per cent; therefore energy digested from molasses beet pulp is $0.85 \times 2,095 \ldots 1,781 \mathrm{kcal}$

Energy digested from casein per day: Energy consumed per day in 521 grams dry casein amounts to $2,854 \mathrm{keal}$. Assuming the same digestibility as for nitrogen, namely 67 per cent, the energy digested from easein is $0.67 \times 2,854 \ldots \ldots \ldots \ldots \ldots \ldots \ldots \ldots \ldots .1,912 \mathrm{kcal}$

Sum of energy digested per day from Sudan hay, molasses beet pulp, and casein:

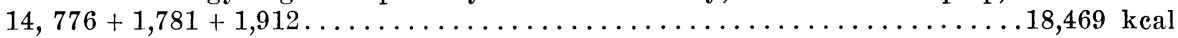

Energy digested from glucose: $25,040-18,469 \ldots \ldots \ldots \ldots \ldots \ldots, 571$ kcal

3: Partial digestibility of energy in glucose:

Energy in glucose fed per day .......................... $7,885 \mathrm{kcal}$ Partial digestibility of energy in glucose $\frac{6,571}{7,885} \times 100 \ldots \ldots \ldots \ldots \ldots 8$ per cent

These results do not imply that 10 to 20 per cent of the glucose was excreted in the feces. Rather, they mean that the addition of glucose slightly lowered the digestibility of food energy. This depression is superimposed upon that of protein digestibility, whose effect on energy digestion is already accounted for in the calculation of the partial digestibility of glucose (sample calculation 2), since only the partially digested fraction of the casein energy figures in that calculation. The partial digestibility of the energy in the reference substance as a whole (casein and glucose) amounts to $80.0 \pm 0.7$ per cent. The allition of glucose distinctly depressed the digestibility of crude fiber in stere calves (Mitchell, Hamilton, and Haines, 1940) and in sheep (Hamilton, $19+9)$.

The partial digestibility of energy in barley, ealculated like that for glucose (ample (alculation 2), was 74 per cent for the trial with the low protein con-

"in this paper, kilocalorie will be abbreviated kcal. A kilocalorie is 1,000 calories. The farm "large "alorie" is obsolescent, and the term "kilogramealorie" is a misnomer. 
tent and 80 per cent for the diet that was balanced by casein (cow 1021). Since it was 74 per cent for the balanced diet with cow 1007 , the difference with cow 1021 may be taken to result from variability rather than balance of the diet. The partial digestibility of barley energy in the second series was 78 and 77 per cent respectively. The four trials with balanced rations led to a mean (weighted with respect to duration of the trials) of $77.3 \pm 1.1$ per cent partial digestibility of the energy in barley. From Morrison's table (1936), by way of comparison, one may calculate for eastern barley an energy digesti-

bility $\left(\frac{\text { total digestible nutrients }}{\text { organic matter plus } 1.25 \times \text { fat }}\right)^{12}$ of 87 per cent.

\section{METHANE}

Methane Production and Intake of Sudan Hay.-In the first series of experiments the methane production was rather uniform. The mean for five main trials (ten results) on maintenance with Sudan hay alone was $37.0 \pm 0.7$ liters methane per kilogram dry Sudan hay eaten. Since 1 liter methane weighs 0.715 gram and since 100 grams of dry Sudan hay contains 75.4 grams of carboyhydrates (p. 520), the methane production in the first series of the trials was $3.5 \pm 0.07$ grams methane per 100 grams of carbohydrates in Sudan hay.

Using our analysis of the Sudan hay and measurement of digested nitrogen, and assuming 40 per cent digestibility for fat (Morrison, 1936), one can estimate that the digestibility of the carbohydrates in Sudan hay was 79 per cent. The methane production, consequently, amounted to $\frac{3.5}{0.79}=4.4$ grams methane per 100 grams of digestible carbohydrates in Sudan hay. This confirms Kellner's results on steers, as summarized to 4.29 grams of methane per 100 grams of digested carbohydrates (Kellner, 1919, p. 96), and those of Armsby and Fries (1915, p. 450) with 4.8 grams of methane per 100 grams of digested carbohydrates as a mean of 43 experiments with roughages, and 4.7 grams of methane as a mean of 22 experiments with rations mixed of roughages and concentrates. Later calculations at Pennsylvania State College (linear interpolations by the method of least squares) produced essentially the same result, adding a complicating rather than clarifying term that implies methane production without food intake (Kriss, 1930; Bratzler and Forbes, 1940).

The methane production during the second series of trials was more variable than during the first. On full-maintenance rations of Sudan hay cow 732 produced 35 and cow 728 produced 40 liters of methane per kilogram of dry hay. The latter's partial methane production ( $\left.\frac{\text { change in methane }}{\text { change in hay }}\right)$ between half maintenance and maintenance was 37 liters per kilogram of dry Sudan hay. Cow 732, however, produced 51 liters of methane per kilogram of dry hay on half-maintenance ration; and her partial methane production between half maintenance and maintenance on Sudan hay was as low as 18 liters of methane

\footnotetext{
${ }^{12}$ Fat-free organic matter plus $2.25 \times$ fat, or organic matter plus $1.25 \times$ fat.
} 
per kilogram of dry Sudan hay. Aside from that one trial on half maintenance with cow 732, our results in the second series of trials confirm those in the first.

Partial Methane Production Resulting from Reference Substance.-Sample calculation 3 (based on trial 16, cow 1007) illustrates the calculation of partial methane production resulting from glucose, on the assumption that casein does not contribute to methane formation. This assumption seems reasonable, since Kellner and his co-workers stated as early as 1896 (p. 287) that they could not detect any influence of protein on the methane formation of steers.

Sample Calculation 3 : Partial Methane Production from Glucose

1. Total methane production per day:

0.715 gram per liter $\mathrm{CH}_{4}$, standard conditions

209 grams

2. Partition of methane production:

Methane production from Sudan hay: $5.258 \mathrm{~kg}$ dry Sudan hay consumed per day contained 75.4 per cent or $3.964 \mathrm{~kg}$ carbohydrates. In maintenance trials, each $\mathrm{kg}$ carbohydrate gave rise to $35 \mathrm{grams}$ methane; the $3.964 \mathrm{~kg}$ carbohydrate would therefore

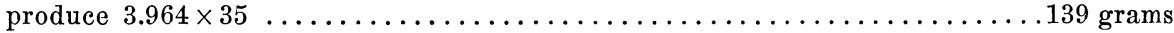

Methane production from molasses beet pulp: 519 grams dry molasses beet pulp consumed per day contained 87 per cent or 452 grams carbohydrates. Assuming formation of 35 grams methane per $\mathrm{kg}$ carbohydrate, the methane production from molasses

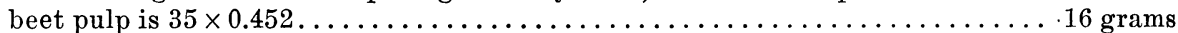

Methane production from hay and molasses beet pulp: $139+16 \ldots \ldots \ldots \ldots 155$ grams

Methane production from glucose, $209-155 \ldots \ldots \ldots \ldots \ldots \ldots \ldots \ldots \ldots$ grams

3. Partial methane production per 100 grams glucose:

Consumed per day: $2.110 \mathrm{~kg}$ glucose (dry matter). Methane production per 100 grams glucose: $\frac{54}{21.10}$. 2.6 grams

The mean partial methane production from glucose, calculated from seven main trials with two cows during the first series of the experiments, amounted to $1.8 \pm 0.34$ grams of methane per 100 grams of dry glucose. This is only half the methane production resulting from the carbohydrates in hay $(3.5 \pm 0.07$ grams of methane), as mentioned above; and the difference is statistically highly significant. In the second series, however, the partial methane production from glucose is higher-namely, 2.4 grams and 2.6 grams of methane per 100 grams of glucose for cows 732 and 728 respectively. In experiments with steers, Mitchell, Hamilton, and Haines (1940, p. 857) did not observe any increase of methane production resulting from the addition of glucose to a basic diet.

With the maintenance rations of the second series, the methane production per 100 grams of glucose was higher than with the production rations. It ranged from 2.9 to as high as 7.4 grams of methane per 100 grams of glucose. The greater variability, the smaller number of trials, and the lower food intake tend to make the last-mentioned results less reliable than those of the first series. A distinct increase of the methane fermentation (per 100 grams of carbohydrate) with a decrease of the rations (alfalfa hay and starch) has been reported by Armsby and Fries (1918, p. 274).

Partial Methane Production Resulting from Barley.-The partial methane production from barley in the first series of trials was 3.6 and 3.2 grams of methane per 100 grams of carbohydrates in barley for cow 1021 and cow 1007 respectively. The corresponding figures for the two cows in the last series are 
2.1 and 4.1 grams of methane, so that the mean for the four main trials is $3.2 \pm 0.4$ grams of methane per 100 grams of carbohydrate in barley, a figure not significantly different from that for carbohydrates in Sudan hay $(3.5 \pm$ 0.07 grams).

\section{METABOLIZABLE ENERGY}

Definition.-Metabolizable energy is that part of the total food energy which is available for any metabolic process in the animal-namely, katabolism when chemical energy is transferred to work or heat; and anabolism, whereby the chemical energy of food is transferred to the chemical energy of animal products - for example body fat, body protein, milk, eggs, or wool. The metabolizable energy is the difference between the heat of combustion in the food and that in all excreta (feces, urine, and methane).

The heat produced by katabolism in the animal body from the chemical energy of the food is regarded here as part of the metabolizable energy of the food, whether it is evolved by the metabolism of microörganisms in symbiosis or parasitosis with the animal or by the metabolism of the animal's own cells. The heat increment likewise includes increase in heat production by increased metabolism of body cells or by increased metabolism of microörganisms in the animal body. From the point of view of energy exchange we are used to regarding the animal, together with its symbionts and parasites, as a unit. Excluding the heat produced by the microörganisms in the animal body from the metabolizable energy would mean, at the present state of research, defining metabolizable energy as a hypothetical rather than a measured quantity.

Metabolizable Energy in Sudan Hay.-The metabolizable energy of Sudan hay in ten main trials on the maintenance level with dry cows averaged to $222.5 \pm 1.4$ kcal per 100 grams of dry matter. The variability is rather low, the coefficient of variation being \pm 1.9 per cent. Even slightly lower-namely, \pm 1.7 per cent-is the coefficient of variation for the metabolizability of the digested energy in Sudan hay (metabolized energy/digested energy), which, as a mean of ten results in the main trails on maintenance, is $77.8 \pm 0.4$ per cent. If the preliminary trials are included, then the mean amounts to $77.4 \pm$ 0.4 per cent. In two maintenance trials of the second series of the experiments 100 grams of dry Sudan hay contained 228 and 215 kcal of metabolizable energy. The details are found in table A of the appendix.

Partial Metabolizable Energy in Reference Substance.-Sample calculation 4 (based on trial 16, cow 1007) illustrates the calculation of the partial metabolizable energy in the reference substance. The metabolizable energy in molasses beet pulp has been estimated from the data in Morrison's tables (1936) and from the mean of 1,616 kcal of metabolizable energy per pound of total digestible nutrients given by M. Kriss (1931). Such an estimate was justified because molasses beet pulp furnished only 7 per cent of the metabolizable energy in the rations.

Sample Calculation 4: Partial Metabolizable Energy in Refrerence Substance AND IN GLUCOSE

1. Metabolizable energy in daily ration $: \ldots \ldots \ldots \ldots \ldots \ldots \ldots \ldots \ldots \ldots 20,890$ kcal

2. Partition of metabolizable energy per day:

Metabolizable energy from Sudan hay: The Sudan hay used contained 2.22 keal of 
metabolizable energy per gram of dry matter; $5.258 \mathrm{~kg}$ dry Sudan hay, consumed daily,

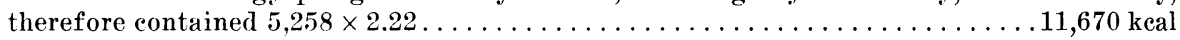

Metabolizable energy from molasses beet pulp: From the total-digestible-nutrient content of molasses heet pulp (Morrison, 1936, p. 978) and from Kriss' (1931, p. 156) figure of $1,616 \mathrm{kcal}$ metaholizahle energy per pound of total digestible nutrients, one may calculate that $1 \mathrm{gram}$ of molasses beet pulp furnished $2.9 \mathrm{kcal}$ metabolizable energy and therefore that 519 grams furnished ......................

Metabolizable energy from hay and beet pulp: $11,670+1,500 \ldots \ldots \ldots \ldots 13,170 \mathrm{kcal}$

Metaholizable energy from reference substance: $20,890-13,170 \ldots \ldots \ldots 7,720 \mathrm{kcal}$ Reference substance fed daily consisted of 2,629 grams dry matter, including 519 grams casein and 2,110 grams glucose.

Metabolizable energy from casein: 519 grams casein contains (according to sample calculation 3) 1,910 keal digestible energy. A partial metabolizability of 100 per cent may be assumed, since the nitrogen excretion in urine was even smaller in the production trials with easein than in the maintenance trials with hay alone. Therefore the metabolizable energy from casein may be considered equal to the digestible energy from

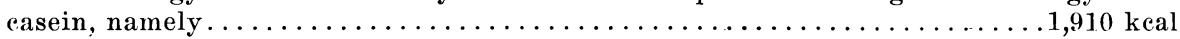

Metabolizable energy from glucose: $7,720-1,910 \ldots \ldots \ldots \ldots \ldots \ldots \ldots, 810 \mathrm{kcal}$

3. Partial metabolizability of energy in reference substance:

Since 2,629 grams of dry reference substance furnished $7,720 \mathrm{kcal}$ of metabolizable energy, 100 grams of dry reference substance furnished ..............293 kcal

Since 2,110 grams of glucose furnished $5,810 \mathrm{keal}$ of metabolizable energy, 100 grams

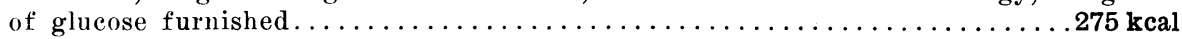

Since the total energy fed daily in glucose amounted to $7,885 \mathrm{kcal}$ and since this amount of glucose furnished $5,810 \mathrm{keal}$ of metabolizable energy, the partial metabolizability of energy in glucose amounted to $\frac{5,810}{7,885} \times 100 \ldots \ldots \ldots \ldots \ldots \ldots \ldots \ldots$ per cent

As a mean of seven trials with two cows in the first series of experiments, the partial metabolizable energy in the reference substance was $301 \pm 5 \mathrm{kcal}$ per 100 grams dry reference substance, or $74 \pm 1.3$ per cent of the total energy in the reference substance.

The utilization of nitrogen from casein was very high, as will be shown later. (See p. 540.) If we assume that the digested energy from casein was 100 per cent metabolizable (no increase in urinary nitrogen resulting from feeding casein), then we calculate the partial metabolizable energy in glucose alone as shown in sample calculation 4 . According to this calculation for the seven main production trials, the mean partial metabolizable energy in glucose was $278 \pm 6.3$ kcal per 100 grams of glucose, or $75 \pm 1.8$ per cent of the total energy in the glucose. In the second trial the metabolizability of glucose seemed somewhat higher-namely, 298 and 290 keal of metabolizable energy per 100 grams glucose, or 80 and 78 per cent of the energy in glucose for cows 732 and 728 respectively.

The duration-weighted means for both series (20 weeks of trials) of partial metabolizable energy in glucose are $283 \pm 5 \mathrm{kcal}$ metabolizable energy per 100 grams glucose, or $76 \pm 1.5$ per cent of the total energy in glucose.

The metabolizability of glucose for maintenance, according to a similar calculation, was rather variable: as a mean of four trials it amounted to $292 \pm 24 \mathrm{kcal}$ per 100 grams of dry glucose, or $78 \pm 6$ per cent of the total energy in glucose.

Mitchell, Hamilton, and Haines (1940) report for steer calves a metabolizable energy in glucose averaging to 65 per cent of the heat of combustion of glucose. They attribute (p. 861) this low metabolizability to the partial de- 
struction of glucose by the paunch flora and to the depressing effect of glucose on the digestibility of polysaccharides.

The partial destruction of glucose in the rumen can, however, hardly be responsible for a low metabolizability, since Mitchell, Hamilton, and Haines found no increase in methane production resulting from the addition of glucose to the ration; the only possible way in which this partial destruction could otherwise account for a lowering of the metabolizability-as this term is defined here and as it is calculated by Mitchell himself-would be the formation of split products excreted in the urine.

Partial Metabolizable Energy in Barley.-The partial metabolizable energy in barley can be calculated from three main production trials of 2 weeks' duration and two trials of 3 weeks' duration by procedure analogous to sample calculation 5 . The duration-weighted means resulting from such calculations are $293 \pm 9.7$ kcal metabolizable energy per 100 grams of dry barley and a metabolizability of $67 \pm 2$ per cent of the total energy in barley.

\section{MAINTENANCE REQUIREMENT AND SUDAN HAY AS FOOD FOR MAINTENANCE}

Definition.-Maintenance means a condition in which an animal is in nutritive equilibrium, which is attained when it neither gains nor loses. Gain or loss may concern any nutritive essential. Thus we may speak of energy maintenance when the animal neither gains nor loses energy ; or protein maintenance when no gain nor toss of nitrogen from the body occurs. In a similar way we can speak of calcium maintenance, phosphorus maintenance, even water maintenance. Maintenance is a dynamic equilibrium. An animal on protein maintenance, for example, may actually lose nitrogen that was part of its tissues; but it replaces this loss by the same amount of nitrogen retained from its food. Maintenance is thus defined as the condition under which the intake of a certain nutritive essential is equal to the sum of all losses of that essential. A fasting animal obviously cannot be on maintenance, according to our definition, which thus differs from the concept of Forbes and his coworkers (1941, p. 19), who apparently use the word maintenance in a wider sense, such as keeping alive, whereas we restrict it to a definite quantitative term.

Maintenance requirement is the amount of a certain food that provides maintenance. Even for a given food, this requirement will of course usually differ for different nutritive essentials. Though a certain amount of Sudan hay may suffice to keep an animal in calcium equilibrium, this amount may be inadequate to keep it in phosphorus equilibrium ; more hay was necessary in our trials to provide energy equilibrium than to provide protein equilibrium. (See p. 570.) Appendix table B summarizes results on feed utilization.

The maintenance requirement changes with the animal's size; and the function between size and maintenance requirement may be different for different essentials. Energy requirement, for example, is closely proportional to the $3 / 4$ power of body weight (Kleiber, 1933), whereas the vitamin-A requirement is proportional to the body weight itself (Guilbert and Hart, 1935).

In this study the requirements of protein and energy only were considered. Fortunately, these two requirements are related to the same function of body 
size, as was discovered by Terroine and his co-workers (1927) and called the Terroine, Sorg-Matter law. This law was confirmed by D. B. Smuts (1935, p. 427), who summarized his own results, with those of Terroine et al., in the statement that $2 \mathrm{mg}$ of nitrogen is required for each "calorie" (in our terminology, kilocalorie, kcal) of basal heat. ${ }^{12}$

Since basal-heat production is most nearly proportional to the $3 / 4$ power of body weight (Kleiber, 1932) ${ }^{14}$ the rate of food intake, as well as the rate of gain and loss of protein or energy in body substance, was calculated per unit of the $3 / 4$ power of body weight. Thus was eliminated as much as possible the effect of differences in body size of the cows. This procedure has been justified against criticism in an earlier publication (Kleiber, 1938). Table $\mathrm{C}$ of the appendix gives the metabolic size for cows of 600 to 1,400 pounds' body weight.

Requirement of Sudan Hay for Protein Maintenance.-In all eight of the main maintenance trials with Sudan hay carried out in the first series of experiments, the cows showed slight gains of nitrogen. There was no correlation between these gains and the nitrogen intake. To get information on the utilization of nitrogen from Sudan hay, we calculated the basic nitrogen requirement according to Smuts' rule mentioned above, using as daily rate of basal metabolism the result of our fasting trials-namely, $86 \mathrm{kcal}$ per $\mathrm{kg}^{3 / 4}$. $^{15}$ (See p. 535.) This leads to a daily maintenance requirement of 0.172 grams net nitrogen per $\mathrm{kg}^{3 / 4}$.

Sample calculation 5 illustrates the calculation of protein utilization on this basis. For the eight trials of the first series, the mean net-nitrogen ${ }^{16}$ content in Sudan hay was $0.49 \pm 0.03$ gram of net nitrogen per 100 grams of dry matter, which is $25 \pm 1.4$ per cent of the total nitrogen and $40 \pm 2.4$ per cent of the digested nitrogen in Sudan hay.

Sample Calculation 5 : Net Nitrogen in Sudan Hay for Maintenance; and RequireMent for Protein Maintenance

1. Total net nitrogen per day:

With a basic nitrogen requirement of 0.172 gram net nitrogen per $\mathrm{kg}^{3 / 4}$ (as explained above), cow 1007, trial 22 , with a metabolic body size of $99 \mathrm{~kg}^{3 / 4}$, required daily $99 \times 0.172$ or 17 grams net nitrogen. In her gained body substance she stored daily 13 grams nitrogen. Basic requirement added to gain equals total net nitrogen $17+13 \ldots \ldots \ldots \ldots 30$ grams

2. Net nitrogen content of Sudan hay:

The 30 grams net nitrogen was supplied by the daily ration of 5,318 grams dry matter in Sudan hay containing 104 grams total nitrogen, of which 64 grams were digested. The Sudan hay therefore supplied net nitrogen as follows:

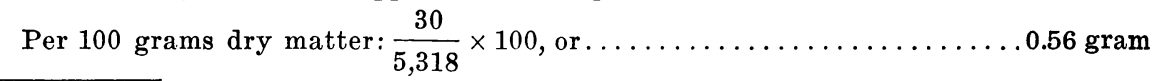

${ }^{13}$ The creatinine fraction of the endogenous urinary nitrogen, however, seems to be in proportion to body weight itself (Brody, Procter, and Ashworth, 1934).

${ }^{14}$ Brody and Procter (1932, p. 99) in a later publication of the same year concluded that "the basal metabolism of mature mammals and of the domestic fowl increases directly with the 0.734 power of body weight." We do not believe that the second, let alone the third, decimal of the exponent has at present real significance; the difference between Brody's 0.734 and of Kleiber's more rounded $3 / 4$ power appears to be unimportant.

${ }_{15}$ In this publication $W^{3 / 4}$ means the body weight in kilograms raised to the $3 / 4$ power, or the metabolic body size of the animal; $\mathrm{kg}^{3 / 4}$ stands for the unit of this metalolic body size. If a metabolic rate (in terms of nitrogen or energy) is given per $\mathrm{kg}^{3 / 4}$, one can estimate the rate of an animal of any size as: (rate per $\mathrm{kg}^{3 / 4}$ ) times metabolic size. The metabolic size of cows weighing 600 to 1,400 pounds is given in table $\mathrm{C}$ of the appendix.

${ }^{10}$ See note p. $51 \delta$. 


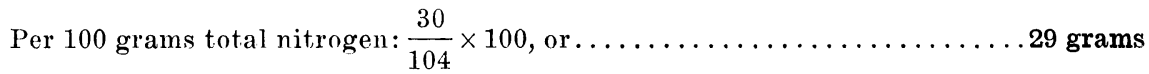

Per 100 grams digested nitrogen: $\frac{30}{64} \times 100$, or 47 grams

3. Requirement for daily protein maintenance per unit of metabolic body size:

Dry matter in Sudan hay: $\frac{0.172}{0.56} \times 100=31$ grams per kg ${ }^{3 / 4}$

I'otal nitrogen in Sudan hay: $\frac{0.172}{29} \times 100=0.59$ gram per $\mathrm{kg}^{\mathrm{*} / \mathrm{t}}$

Digested nitrogen in Sudan hay: $\frac{0.172}{47} \times 100=0.37$ gram per kg ${ }^{3 / 4}$

The nitrogen losses in urine in one of four trials of the second series were far out of line with all the other corresponding data. If this result is omitted, a mean of $0.59 \pm 0.03$ gram net nitrogen per 100 grams of dry Sudan hay is found for the second series. This is $25 \pm 1.5$ per cent of the total nitrogen or $42 \pm 2.6$ per cent of the digestible nitrogen. Although the hay had a higher nitrogen content in the second series than in the first (see table 3 ), the utilization of the nitrogen for maintenance was the same in both series.

Sample calculation 5 shows how to calculate the requirement of Sudan hay for protein maintenance on the basis of Smuts' rule. This calculation, applied to the results of eight chief maintenance trials of the first series, results in a mean daily requirement of $36 \pm 2$ grams of dry Sudan hay, $0.71 \pm 0.04$ gram of total nitrogen or $0.44 \pm 0.03$ gram of digestible nitrogen per $\mathrm{kg}^{3 / 4}$. The corresponding figures for the second series are $29 \pm 2$ grams of dry hay, $0.68 \pm 0.04$ gram of total nitrogen, or $0.41 \pm 0.02$ gram of digested nitrogen per $\mathrm{kg}^{3 / 4}$.

Requirement of Sudan Hay for Energy Maintenance.-The daily fasting katabolism on the fourth and fifth day of fast was 89 and $83 \mathrm{kcal} \mathrm{per} \mathrm{kg}^{3 / 4}$ for two of the cows respectively. These results are calculated on the basis of 4.7 kcal per liter of $\mathrm{O}_{2}$ consumed. It is considerably above the interspecific mean of $72 \mathrm{kcal}$ per $\mathrm{kg}^{3 / 4}$ (Kleiber, 1932) ; or the mean of $71.75 \mathrm{kcal}$ per $\mathrm{kg}^{3 / 4}$ reported by Mitchell, Hamilton, and Haines (1940) as the fasting heat production of four steers ranging in weight from 400 to 500 pounds; or the mean for fasting dry cows of $73 \mathrm{kcal}$ per $\mathrm{kg}^{3 / 4}$ calculated from results given by Forbes and his co-workers (1927). The difference, which may be regarded as a stimulating effect of pregnancy on metabolic rate, is in line with our unpublished observations on rats. The energy loss (heat production of animal and chemical energy in urine) of the cows amounts to 93 and $90 \mathrm{kcal} \mathrm{per} \mathrm{kg}^{\mathrm{*}}$ of the two cows.

The basic requirement for net energy so far cannot be explained in terms of well-understood energy needs. The work of the heart and the respiratory system and even the osmotic work of internal organs do not seem to sum up to the actual energy expenses of a fasting and resting animal. Even if they did, it would be rather unsatisfactory to "explain" the oxidation of body tissue as necessary for the transport of oxygen, which in turn is necessary for the oxidation of body tissues. Apparently the only satisfactory teleological explanation of the basal metabolism is a comparison to the idling of a car, without starter, in order to have it ready for immediate action-that is, the mainte- 
nance of a state of physiological alertness. At present, however, it is hard to explain rationally why, above the critical temperature, this idling should require a definite amount of energy, instead of some multiple or fraction of that amount. We can therefore reasonably talk of the heat requirement of a thermostat or of an animal below its critical temperature for maintaining a constant body temperature, but we have not yet a corresponding understanding for a requirement of energy other than heat, because we lack a criterion analogous to temperature. Before such a requirement is known, one can hardly speak of utilization of body substance by a starving animal (above the critical temperature), because utilization implies a purpose.

This consideration makes it somewhat difficult for us to understand the theoretical significance of Forbes and his co-workers' (1941) derivation of a "minimum base value of animal heat production." This term is defined as the difference between the basal metabolism and the heat increment, which latter would be observed if the body substance, katabolized by the fasting animal, were fed to the animal at or above the maintenance level. The derivation is based on the assumption that the animal has a certain minimum requirement of energy other than heat (but apparently kinetic) and that in order to meet this requirement a starving animal "utilizes" its own body substance, "wasting" some of the chemical energy of this substance as heat increment.

Even before an energy requirement (aside from heat) of a starving animal can be defined clearly, and before the heat increment of food is more completely understood, the "minimum base value of heat production" might be helpful as an empirical constant, useful for the presentation of animal heat production as a linear function of nutritive level. The minimum base value calculated by Forbes and his co-workers does not, however, seem to fit some of their own results such as those with different levels of intake of alfalfa hay and corn meal (1941, table 5, p. 22). Mitchell, Hamilton, and Haines (1940) question the validity of the experimental bases (as such) of Forbes's theory of the minimum base value.

Considering these difficulties, we decided that our calculations concerning the utilization of Sudan hay for energy maintenance should be based on the daily rate of fasting energy loss obtained by direct measurements. This is the simplest and clearest procedure, anyway. Sudan hay for energy maintenance is used, from the farmer's point of view, to prevent the losses of energy from body substance that would occur without food. These losses (heat loss of animal + chemical energy in urine) in our trials average $92 \mathrm{kcal}$ per day per $\mathrm{kg}^{3 / 4}$. Net energy in the maintenance food, or the saving of energy in body substance which would be lost without food, is thus $92 \mathrm{kcal}$ per $\mathrm{kg}^{3 / 4}$. None of our rations was exactly a maintenance ration. In all trials reported here, gain or loss of body substance and, consequently, of energy occurred. The total net energy of the ration is then calculated by adding the energy in the gained body substance to, or subtracting that in the lost body substance from, the net energy for maintenance, which was calculated as 92 times the metabolic size of the cow in $\mathrm{kg}^{3 / 4}$. Sample calculation 6 demonstrates this calculation for cow 1007 , trial 22 , body weight $457 \mathrm{~kg}$, metabolic body size $99 \mathrm{~kg}^{\text {\% }}$. There is a question whether the energy of gain is really directly comparable with the energy of loss-whether, in other words, partial efficiency of energy utiliza- 
tion above and below the maintenance level is equal. This question becomes, however, less important as the losses and gains of energy become smaller. It is not important when one succeeds in feeding close to the maintenance requirement.

Sample Calculation 6 : Net Energy in Sudan Hay for Maintenance, and Requirenent For ENERgy MaINTENANCE

1. Total net energy per day:

During fasting, the cow (1007) lost daily as heat plus chemical energy in urine 92 keal per $\mathrm{kg}^{*} \%$. Her basic energy requirement in this trial (22) therefore amounted to $92 \times 99$, or $9,108 \mathrm{kcal}$. In her gained body substance she stored daily $870 \mathrm{kcal}$ of chemical energy. Basic energy requirement added to gain in energy equals total net energy 9,108 plus 870

2. Net energy content of Sudan hay:

$9,978 \mathrm{kcal}$

The $9,978 \mathrm{kcal}$ net energy was supplied by the daily ration of 5,318 grams dry matter in Sudan hay containing $22,470 \mathrm{kcal}$ total energy, of which $15,210 \mathrm{kcal}$ was digested. The Sudan hay therefore supplied net energy as follows:

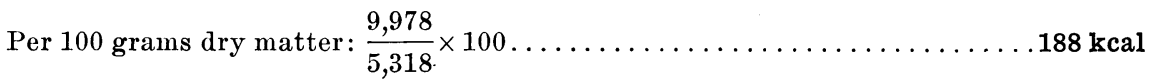

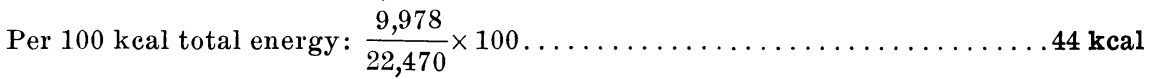

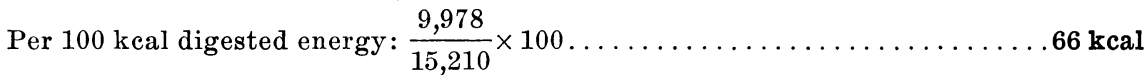

3. Requirement for daily energy maintenance per unit of metabolic body size:

Dry Sudan hay: $\frac{92}{188} \times 100=49$ grams per $\mathrm{kg}^{3 / 4}$

Total food energy in Sudan hay: $\frac{92}{44} \times 100=210 \mathrm{kcal}$ per kg ${ }^{2 / 4}$

Digested energy in Sudan hay: $\frac{92}{66} \times 100=140 \mathrm{kcal}^{\mathrm{k}} \mathrm{per} \mathrm{kg}^{3 / 4}$

As an average of eight results in main trials of the first series, the net energy in Sudan hay for maintenance amounts to $176 \pm 5 \mathrm{kcal}$ per 100 grams of dry matter, $62 \pm 2$ per cent of the digested and $80 \pm 2$ per cent of the metabolizable energy in Sudan hay. The corresponding figures for the two trials of the second series are 135 and 151 kcal per 100 grams of dry matter, 47 and 54 per cent of the digestible and 59 and 70 per cent of the metabolizable energy.

When the net energy for maintenance in hay is known, then one can of course also estimate how much hay must be fed to produce neither gain nor loss of energy. Sample calculation 6 shows this procedure.

From the hay of the first series of trials the cows needed for energy maintenance (on the average of eight trials) $52 \pm 2$ grams of dry matter, $150 \pm 4$ kcal of digested energy, or $116 \pm 3 \mathrm{kcal}$ of metabolizable energy per day per $\mathrm{kg}^{3 / 4}$. The corresponding figures for the two maintenance trials of the second series are 68 and 61 grams of dry matter, 196 and $171 \mathrm{kcal}$ of digested energy, and 156 and $132 \mathrm{kcal}$ of metabolizable energy. Either the hay of the first series was definitely more nutritious for maintenance than that of the second series, or else the cows of the first series utilized the energy in the hay more efficiently than did the cows in the second series.

The mean requirement of Sudan hay for protein maintenance was $36 \pm 2$ grams per $\mathrm{kg}^{3 / 4}$ per day in the first series ; $29 \pm 2$ grams of dry matter per 
$\mathrm{kg}^{\mathrm{a} / 4}$ in the second. Thus the cows needed considerably more Sudan hay for energy maintenance than for protein maintenance.

The hay dry matter of the first series was more effective for energy maintenance, but less effective for protein maintenance, than the hay dry matter of the second series. Table 7 summarizes these results.

Sudan hay is more than rich enough in protein as a maintenance food.

$$
\text { Möllgaard's factor } \mathrm{K} \text {, which is } \frac{\text { fattening energy in protein }}{\text { total fattening energy }} \text {, of Sudan hay }{ }^{17}
$$

was 0.11 , thus slightly higher than the 0.10 recommended by Möllgaard for maintenance. Judging from the present trials, a Möllgaard ratio of 0.08 in the maintenance ration would have provided sufficient protein.

TABLE 7

Dry MatTer of Sudan Hay Needed For Maintenance Per Day PER KG ${ }^{3 / 4}$

\begin{tabular}{|c|c|c|}
\hline Trial series & $\begin{array}{l}\text { Protein } \\
\text { main- } \\
\text { tenance, } \\
\text { grams } \\
\text { per day } \\
\text { per kg. }{ }^{3 / 4}\end{array}$ & $\begin{array}{c}\text { Energy } \\
\text { main- } \\
\text { tenance, } \\
\text { grams } \\
\text { per day } \\
\text { per kg. }{ }^{3 / 4}\end{array}$ \\
\hline 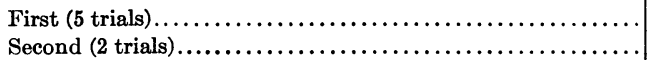 & $\begin{array}{l}36 \pm 2 \\
29 \pm 2\end{array}$ & $\begin{array}{l}52 \pm 2 \\
64 \pm 4\end{array}$ \\
\hline
\end{tabular}

Partial Utilization of Reference Substance for Maintenance.-Four trials enable us to calculate the partial net nitrogen in casein for maintenance. One cow (732) seems to have been considerably and consistently more efficient in utilizing casein than the other cows. The means for four results are as follows : 100 grams of dry casein, added to a half-maintenance ration of Sudan hay, saved $16.7 \pm 2.3$ grams of nitrogen of the animal body (net nitrogen). The partial net nitrogen in casein under those circumstances amounted to $112 \pm 15$ per cent of its total nitrogen, or to $196 \pm 16$ per cent of its digestible nitrogen.

As mentioned before (p. 525), the partial digestibility of casein was rather low, especially in the maintenance trials. The added casein, however, increased as a supplement the biological value of the hay proteins correspondingly, so that 1 gram of casein added to the hay ration actually saved (on the average) 1 gram of body nitrogen from decomposition.

The same four trials just mentioned can be used to calculate the utilization of the energy in the reference substance (casein and glucose) for maintenance. The results vary a great deal. There is no significant difference in the energy utilization between the two trials during which casein and glucose only were fed in the morning and hay only in the evening, and the two other trials during which hay and reference substance were fed together twice a day. The reference substance (containing 11.5 per cent casein and 88.5 per cent glucose) had a partial net-energy effect for maintenance (in addition to Sudan hay) of $120 \mathrm{kcal}$ net energy per 100 grams when fed together with the hay; and of $126 \mathrm{kcal}$ net energy when fed alone in the morning, the hay being fed alone in the evening.

\footnotetext{
${ }^{17}$ This hay contained 12.5 per cent protein, with a digestibility of 67 per cent.
} 
The mean of all four results is $123 \pm 35 \mathrm{kcal}$ net energy per 100 grams of dry reference substance; or a partial efficiency for maintenance of $31 \pm 10$ per cent of the total, $36 \pm 12$ of the digestible, and $40 \pm 9$ per cent of the metabolizable energy in the reference substance.

An attempt to calculate the partial net energy in glucose alone, by assuming that the energy utilization in casein is equal to the nitrogen utilization in casein, led to a very low utilization of glucose-in one case even to a negative net-energy value of glucose for maintenance. The type of feeding-hay and reference substance mixed, or hay only in the evening and reference substance alone in the morning-did not influence the partial utilization of glucose, which on the average was $65 \pm 39$ kcal energy per 100 grams of glucose, corresponding to $18 \pm 10 \mathrm{kcal}$ of net energy per $100 \mathrm{kcal}$ of total energy in glucose.

\section{PROTEIN AND ENERGY UTILIZATION FOR LACTATION}

Definition.-By protein utilization or energy utilization we mean in this publication the transfer of food protein or food energy to protein or energy in the animal's body or in the animal's product-that is, into a form which is useful from the farmer's point of view. We thus use the concept "utilization" in a more restricted sense than Forbes and his collaborators (1941): they mention the energy expense of utilization of katabolized body nutrients and the net energy of internal work, by which they probably mean the work of the heart and other organs necessary for providing oxygen for the katabolism of body nutrients. Since the farmer as a rule cannot use the heat produced by his animals, the burning up of body nutrients for internal work is, in animal production, not a utilization but a waste. The usefulness of the maintenance food is then measured by the amount of this waste that it prevents. This is the basis for Armsby's definition of the net energy for maintenance. (1922, p. 271). The net energy of a ration for maintenance is the amount of energy of body substance that the ration saves from being transferred to heat.

The entire ration of a producing animal is useful in two ways : first, it prevents loss of body substance; second, it provides material and energy for the animal's product, such as milk, and for its gain in body substance. The net energy of such a ration can thus be formulated as follows : net energy of ration equals net energy for maintenance plus energy in product (milk, etc.) plus energy in gained body substance. This formulation is correct also when the animal loses body substance, because such a loss enters into the calculation as a negative gain.

In analogy to net energy, we may speak of net nitrogen as a criterion for the utilization of protein and may formulate: net nitrogen of ration equals net nitrogen for maintenance plus nitrogen in product plus nitrogen gain in body.

Partial Utilization of Nitrogen from Casein.-The net nitrogen for maintenance of the cows can be calculated on the basis of Smuts' rule mentioned before (p. 534), as follows :

$N$ (net) for maintenance $=0.172 W^{3 / 4}$, where $W$ is the body weight of the cows in kilograms and $N$ (net) is the number of grams of net nitrogen required per day. The calculation is based on the mean basal metabolism of 86 keal per $\mathrm{kg}^{\mathrm{*} / \mathrm{t}}$ on the fourth and fifth day of fast. 
Addition of the nitrogen in milk per day and the nitrogen gained daily as body substance to the net nitrogen for maintenance leads to the total net nitrogen per day of our production trials. ${ }^{18}$ From this "total net N" we subtract the net nitrogen in Sudan hay which, according to the maintenance trials, is 25 per cent of the total nitrogen in Sudan hay. (See p. 535.) This procedure is justified for calculating partial effects because the amount of hay fed for the production trials corresponded approximately to the maintenance level at which the utilization of nitrogen of Sudan hay was measured. We also subtract, from the total net nitrogen, the net nitrogen in molasses beet pulp, assuming that the nitrogen in beet pulp is utilized with the same efficiency as the nitrogen in hay. Admittedly, this is a somewhat wild assumption; but since the amount of nitrogen from beet pulp in the ration is small, even a great relative error in estimating its utilization would not much change the result.

Sample calculation 7 illustrates this calculation. The figures are based on trial 16, cow 1007, body weight $460 \mathrm{~kg}$, metabolic body size $99 \mathrm{~kg}^{3 / 4}$.

\section{Sample Calculation 7 : Partial Net Nitrogen in Casein}

\section{Total net nitrogen per day:}

With a basic nitrogen requirement of 0.172 gram net nitrogen per $\mathrm{kg}^{3 / 4}$, as explained on p. 534, the cow (1007) in this trial (16) required daily $99 \times 0.172$ or 17 grams of net nitrogen. In her milk she secreted daily 43 grams of nitrogen. She stored in her gained body substance 19 grams of nitrogen. Basic nitrogen requirement, added to nitrogen in milk, plus nitrogen in gained body substance, equals total net nitrogen $(17+43+19) \ldots 79$ grams

2. Partition of net nitrogen in food:

When Sudan hay was fed alone, the total nitrogen was utilized with an efficiency of 25 per cent. (See p. 535.) With this efficiency, the 117 grams total nitrogen in the daily Sudan-hay ration of this trial contributed to the daily net nitrogen $0.25 \times 117 \ldots 29$ grams

With the same efficiency the 6 grams of total nitrogen in molasses beet pulp con-

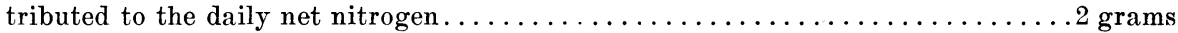

The net nitrogen in the daily hay and molasses beet pulp amounted, therefore, to 29

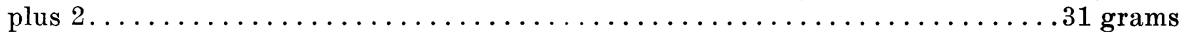

Subtraction of this amount from the 79 grams of total net nitrogen gives the net nitrogen supplied by the easein in the daily ration $79-31 \ldots \ldots \ldots \ldots \ldots \ldots 48$ grams

3. Partial utilization of nitrogen in casein:

The 521 grams of dry matter in casein fed per day contained, per 100 grams, $\frac{48}{521} \times 100$

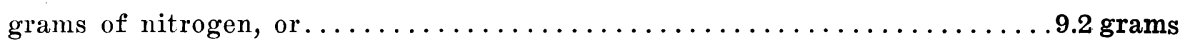

The 70 grams total nitrogen in casein fed per day contained, per 100 grams, $\frac{48}{70} \times 100$

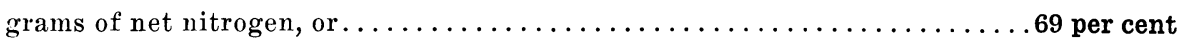

The 47 grams of nitrogen digested (in terms of partial digestibility) from casein fed per day contained, per 100 grams, $\frac{48}{47} \times 100$ grams of net nitrogen, or.......102 per cent

The partial net nitrogen in casein for seven lactation trials of the first series averages $10.5 \pm 0.8$ grams of net nitrogen per 100 grams of dry casein; the mean efficiency is $77 \pm 6$ per cent of the total nitrogen.

The partial utilization of the total nitrogen from casein in the second series of trials was 69 and 84 per cent for the two cows. The simple means of all nine

${ }^{18}$ Maynard's (1937, p. 421) formula for calculating the biological value of protein for milk production does not contain the net nitrogen for maintenance; his results should therefore be strictly comparable only within a given plane of nutrition. 
trials with casein amount to $10.7 \pm 0.6$ grams of partial net nitrogen per 100 grams of dry easein and $77 \pm 5$ grams of partial net nitrogen per 100 grams of total nitrogen in casein. The coefficient of variation in the utilization of nitrogen from casein for these nine trials amounts to \pm 19 per cent.

In their application, these results for the partial nitrogen utilization are possibly limited to our experimental conditions. These conditions, however, were so chosen that they approach reasonably close to practical dairy feeding, at least as far as food level, amount of roughage, and protein ratio are concerned. In this respect our rations may be regarded as reasonably well balanced.

Partial Utilization of Nitrogen from Barley.-The partial net nitrogen in barley was calculated like that in casein (sample calculation 7). From the total net nitrogen (in maintenance, milk, and gain), however, we had to subtract not only the partial net nitrogen from hay $(0.25 \times$ total nitrogen in hay) and beet pulp $(0.25 \times$ total nitrogen in beet pulp), but also from caseinnamely, 77 per cent of the nitrogen furnished in casein according to the partial utilization of nitrogen from casein mentioned in the previous paragraph. The results of two trials of the first series and two trials of the second series averaged $0.96 \pm 0.24$ gram of partial net nitrogen per 100 grams of dry barley and $52 \pm 12$ grams of partial net nitrogen per 100 grams of total nitrogen in barley.

One trial was carried out with a low-protein ration, feeding barley alone as concentrate in addition to Sudan hay. In this one trial the partial utilization of nitrogen from barley was higher than in any other trial-namely, 81 per cent of the total nitrogen fed in barley. Since the partial digestibility of nitrogen from barley in this trial was 67 per cent, the partial utilization of the partial digested nitrogen was 121 per cent, indicating an increase in the utilization of hay protein by the addition of barley at low-protein level. The higher efficiency in utilizing protein was, however, at the cost of greater waste of energy. Conceivably, therefore, the optimum protein-to-energy ratio in the food may be different for protein utilization and for energy utilization. If this observation should be confirmed, one must conclude that the idealthat is, the most economical-balance of a ration for animal production is not a biological constant, but depends on the relative costs for protein and food energy.

Partial Utilization of Energy from Glucose.-To derive the partial net energy in glucose, we calculated the total net energy in a trial as the sum of the net energy for.maintenance, the energy in milk, and the energy gained as body substance. From this total net energy we subtracted the partial net energy from hay, from beet pulp, and from casein. The remainder is the partial net energy from glucose.

The following calculation illustrates this procedure. The figures are based on trial 16, cow 1007 , body weight $460 \mathrm{~kg}$, metabolic body size $99 \mathrm{~kg}^{3 /}$.

\section{Sample Calculation 8 : Partial Net Fnergy in Glucose for lactation}

\section{Total net energy per day:}

With a basic net-energy requirement per day of $92 \mathrm{kcal}$ per $\mathrm{kg}^{\%}$, as explained on $\mathrm{p} .537$, the cow (1007) in this trial (16) required daily $92 \times 99$ or 9,108 keal of net energy for maintenance only. In her milk she gave off daily $6,060 \mathrm{kcal}$ of chemical energy. She lost 
from her body substance daily $930 \mathrm{kcal}$ of chemical energy. The total net energy per day therefore amounts to $9,108+6,060-930$, or . . . . . . . . . . . . . .

2. Partition of net energy supplied by feed:

When Sudan hay was fed alone, 100 grams of its dry matter supplied 176 keal net energy. (See p. 537.) The 5,258 grams dry Sudan hay consumed daily in this trial therefore supplied $5,258 \times 1.76 \mathrm{kcal}$ net energy, or . . . . . . . . . . . . . . . . .

Assuming the same efficiency of utilization of metabolizable energy for molasses beet pulp as for hay, 100 grams of dry matter in molasses beet pulp contains $176 \times \frac{286}{222}$ or 226 keal net energy. The 519 grams of dry matter in molasses beet pulp consumed in this trial per day therefore supplied $5.19 \times 226 \mathrm{kcal}$ net energy, or...........1,173 keal

Assuming that in casein the energy was utilized with the same efficiency as the nitrogen (77 per cent; see p. 540), the 2,854 keal total energy in casein consumed daily during this trial supplied $0.77 \times 2,854 \mathrm{kcal}$ net energy, or.................

Subtracting the net energy supplied by hay, beet pulp, and casein from the total net energy gives the net energy supplied daily by glucose $\ldots \ldots \ldots \ldots \ldots \ldots \ldots 1,613 \mathrm{kcal}$

3. Partial net energy in glucose:

Since the daily ration contained 2,110 grams of glucose, 100 grams of glucose sup-

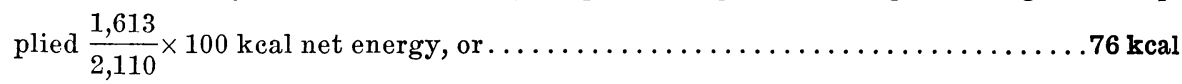

Since the 2,110 grams of glucose fed daily contained 7,885 kcal total energy, $100 \mathrm{kcal}$ of total energy in glucose supplied $\frac{1,613}{7,885} \times 100 \mathrm{kcal}$ net energy, or . . . . . 20.5 per cent

A partial net-energy content in glucose of only 20 per cent of the total energy is the lowest result obtained in our trials. The mean for the first series of trials is $141 \pm 16$ kcal of partial net energy per 100 grams of glucose, or $38 \pm 4$ per cent of the total energy. This would amount to $\frac{38}{0.83}=46$ per cent of the partial digested energy in glucose, or $\frac{38}{0.75}=51$ per cent of the partial metabolizable energy in glucose. For nine trials of both series the partial net energy in glucose averages $154 \pm 15 \mathrm{kcal}$ per 100 grams of glucose, which is $41 \pm 4$ per cent of the total energy in glucose.

This seems to be a surprisingly low efficiency of energy utilization, particularly of a material like glucose, which needs no change in order to become a normal component of the blood.

The results of twelve trials on steer calves by Mitchell, Hamilton, and Haines (1940) average $49.9 \pm 5.4$ calories of net energy per 100 calories of metabolizable energy of glucose. The average efficiency of utilization of energy in glucose for lactation in our trials was thus equal to that for growing animals in the trials of Mitchell and his co-workers and does not differ significantly from the efficiency of converting metabolizable energy of starch into energy of body fat in adult steers-namely, $54 \pm 2$ per cent (Kellner and Köhler, 1900 ) or 47.8 per cent (Armsby and Fries, 1918). This latter comparison is somewhat surprising. In general the efficiency of energy utilization for milk production appears to be higher than for fattening. In ten trials of Möllgaard (1931, p. 327) with protein ratios (protein net energy divided by net food energy) in a range without effect on energy utilization (from 0.14 to 0.23 ) the cows produced 1,000 kcal of milk energy from food that in adult steers 
would have yielded on the average only $837 \mathrm{kcal}$ of energy in body fat. According to Niels Hansson's (1923, table 4) figures, 100 calories of net energy for fattening in feeds with a low protein content will yield, on the average, 124 calories of net energy in milk production. For high-protein feeds the increased efficiency of total food energy for lactation over that for fattening is still greater because the metabolizability of the digested protein is increased. (See Kleiber, 1929, note 12.) Kriss (1931, p. 160), probably on the basis of the Scandinavian work, concludes that 1 therm of metabolizable energy is equivalent to 0.575 therm of net energy for fattening, but to 0.693 therm of milk energy.

Future investigation should show whether or not the relatively low utilization of the metabolizable energy of glucose (or its high heat increment), observed in our lactation trials, is related to a greater carbon dioxide production in the rumen or to an increased metabolic rate of the cow's own tissues.

Possibly glucose, which can be readily taken into the blood stream, may for this very reason lead to a temporarily excessive metabolic rate. A scheme of such an effect is given by Kleiber (1936). Soskin and Levine (1937) have shown that the rate of "dextrose utilization" increases with increased level of blood sugar. By "utilization" they mean the disappearance of sugar from the blood and extra hepatic tissues "to produce useful energy and heat" (Soskin, 1941). (This terminology is rather unfortunate: not enough is known concerning the usefulness of the form of energy that the animal derives, aside from heat or prior to heat, from the chemical energy of the nutrients.) Soskin thus observed an increased rate of metabolism of sugar with an increased level of blood sugar.

From experiments on man, Carpenter (1940) concluded: "The increases in carbohydrate combustion during the 3 hours following food ingestion were greater, the greater the amounts of reducing and hydrolyzable sugars in the foods, and smaller the greater the amounts of starch or fat in the foods."

It is further to be remembered that we derived the partial efficiency of utilization of energy from glucose by assuming that the partial efficiency of utilization of casein energy was equal to the partial efficiency of utilization of casein nitrogen. This assumption may not be correct. The transfer of food casein to casein in milk involves possibly greater energy losses than nitrogen losses-that is, glucose energy may conceivably be spent in utilizing food casein for lactation.

The partial net energy in the reference substance as a whole, casein plus glucose, was on the average of nine trials (including both series of the experiment) $50 \pm 3$ per cent of the total, $61 \pm 4$ per cent of the partial digestible, and $67 \pm 4$ per cent of the partial metabolizable energy in the reference substance.

Partial Utilization of Energy from Barley.-Sample calculation 9 illustrates the calculation of the partial net energy in barley. The figures are based on trial 18, cow 1007, body weight $473 \mathrm{~kg}$, metabolic body size $101 \mathrm{~kg}^{3 / 4}$.

Sample Calculation 9 : Partial Net Energy and Nitrogen-free Net Energy in Barley FOR LACTATION

1. Total net energy per day:

With a basic net-energy requirement per day of $92 \mathrm{keal}$ per $\mathrm{kg}^{\mathrm{*} / 4}$, as explained on p. 537, the cow (1007) in this trial (18) required daily $92 \times 101$ or $9,290 \mathrm{kcal}$ of net energy for maintenance only. In her milk she gave off daily $6,360 \mathrm{kcal}$ of chemical energy. She 
lost from her body substance daily $550 \mathrm{kcal}$ of chemical energy. The total net energy per day therefore amounts to $9,290+6,360-550$, or . . . . . . . . . . . .

2. Partition of net energy supplied by feed:

When Sudan hay was fed alone, 100 grams of its dry matter supplied 176 kcal net energy. (See p. 537.) The 5,219 grams of dry Sudan hay consumed daily during this trial therefore supplied $5,219 \times 1.76 \mathrm{kcal}$ net energy, or . . . . . . . . . . . . .

Assuming the same efficiency of utilization of metabolizable energy for molasses beet pulp as for hay, 100 grams of dry matter in molasses beet pulp contains $176 \times \frac{286^{19}}{222}$ or 226

keal net energy. The 386 grams of dry molasses beet pulp consumed daily in this trial therefore supplied $3.86 \times 226 \mathrm{keal}$ net energy, or .................. $872 \mathrm{kcal}$

Assuming that in casein the energy was utilized with the same efficiency as the nitrogen ( 77 per cent; see p. 540), the 1,332 keal total energy in easein consumed daily during this trial supplied $0.77 \times 1,332 \mathrm{keal}$ net energy, or .................. $026 \mathrm{kcal}$

Subtracting the net energy supplied by hay, beet pulp, and casein from the total net energy gives the net energy supplied daily by barley: $15,100-(9,185+872+1,026) \ldots .4,017 \mathrm{kcal}$

3. Partial net energy in barley:

The 4,017 kcal net energy supplied by 2,396 grams dry barley means $\frac{4,017}{2,396} \times 100$ or 168 kcal net energy per 100 grams dry barley.

The 4,017 kcal net energy supplied by 10,423 keal total energy in barley means $38 \mathrm{kcal}$ net energy per $100 \mathrm{kcal}$ total energy in barley.

The protein energy (grams nitrogen $\times 35.6$ ) consumed daily in barley amounts to $1,353 \mathrm{kcal}$. Assuming the efficiency of utilization of protein energy to be 21 per cent, which is the efficiency of nitrogen utilization in this trial, the net energy supplied from the barley protein amounts to $0.21 \times 1,353$, or ....................284 keal

Subtracting this amount from 4,017 kcal leaves the partial "nitrogen-free" net energy in barley $\ldots \ldots \ldots \ldots \ldots \ldots \ldots \ldots \ldots \ldots \ldots \ldots \ldots \ldots \ldots \ldots \ldots \ldots \ldots \ldots \ldots \ldots \ldots, 733 \mathrm{kcal}$ This means $\frac{3,733}{2,396} \times 100$ or $156 \mathrm{kcal}$ "nitrogen-free" net energy per 100 grams dry barley.

In trial 14 without casein supplement and with 15.4 per cent protein energy in the total food energy, the partial net energy in barley amounted to $156 \mathrm{kcal}$ per 100 grams of dry barley. In four other trials in which the barley was supplemented by casein, so that the protein energy amounted to 18.2 per cent of the total food energy, the partial net energy in barley averaged to $194 \pm 25$ kcal net energy per 100 grams of dry matter in barley, ${ }^{20}$ or to $44 \pm 6$ per cent of the total, $57 \pm 7$ per cent of the digestible, and $66 \pm 6$ per cent of the metabolizable energy in barley.

The calculation of the "nitrogen-free" net energy in barley rests on the assumption that the efficiency of utilizing protein energy is equal to the efficiency of utilizing nitrogen. Sample calculation 9 shows this calculation. The mean result from four trials with casein supplementing the barley amounts to $160 \pm 19 \mathrm{kcal}$ "nitrogen-free" net energy per 100 grams of dry barley or $42 \pm 5$ per cent of the total nitrogen-free food energy in barley.

In the trial in which barley was fed without casein, the nitrogen-free net energy amounted to only $100 \mathrm{kcal}$ per 100 grams of dry barley, or 27 per cent of the total nitrogen-free food energy.

\footnotetext{
${ }^{10}$ Ratio of metabolizable energy per 100 grams of dry molasses beet pulp and dry hay.

${ }^{20}$ According to Niels Hansson, 100 grams of barley contain $170 \mathrm{kcal}$ of net energy for fattening and 211 keal for milk production.
} 


\section{FOOD VALUE OF BARLEY}

The nutritive value of barley with respect to protein and energy can now be calculated as the amount of casein and of glucose that can be replaced by 100 grams of dry matter of barley, provided either of these feeds is a part of a balanced ration for lactation, containing enough Sudan hay to cover the maintenance requirement.

Our experimental data offer three different methods for calculating this casein glucose equivalent of barley.

Calculation from Pair Trials.-The partial net nitrogen per 100 grams of dry barley measured with one cow can be compared with the partial net nitrogen per 100 grams of casein measured in the same trial with the pairmate of the barley cow. This procedure is known as the method of pair trials.

Four quotients $\left(\frac{\text { partial net nitrogen in } 100 \text { grams barley }}{\text { partial net nitrogen in } 100 \text { grams casein }} \times 100\right)$ thus obtained average to a mean of $9.4 \pm 1.5$ grams of casein as equivalent to 100 grams of barley. In the one trial where the barley was not supplemented with casein and where, accordingly, the protein:energy ratio in the ration was lower than normal, 100 grams of barley represented a protein equivalent of 15 grams of casein.

The nitrogen-free glucose equivalent of barley measures the nutritive effect of the food energy in barley in addition to the energy already involved in utilizing protein. This nitrogen-free glucose equivalent, calculated for four pair trials (as with the casein equivalent) amounted to $107 \pm 18$ grams of glucose replaced by the nitrogen-free energy of 100 grams of dry barley. The pair trial with the casein-free barley ration led to a nitrogen-free glucose equivalent of 97 grams of glucose per 100 grams of dry barley.

Calculation from Period Trials.-Instead of comparing the results for two eows in the same period, one may compare the effect of casein in one period with the effect of barley in another period with the same cow. This procedure is called the method of period trials. The partial net nitrogen from barley obtained with cow 1007 in trial 18, for example, is compared with the partial net nitrogen from casein obtained with the same cow in other periodsnamely trials $12,14,16$, and 20 . (See table 1.)

Four quotients resulting from this method lead to a mean of $8.9 \pm 2.3$ grams of casein equivalent per 100 grams of dry barley.

The mean of the four period calculations for the nitrogen-free glucose equivalent amounts to $97 \pm 16$ grams of nitrogen-free glucose equivalent per 100 grams of dry barley.

Calculation from Combined Pair and Period Trials.-One can use the available data most fully by comparing the partial net nitrogen in barley obtained in our trial with each cow to the partial net nitrogen in casein obtained with both cows in all reference trials for one series. The procedure is as follows :

Sample Caiculation 10: Casein-Glucose Equivalent of Barley (Combined Pair and

1. Casein equivalent: Period Method)

Partial net nitrogen per 100 grams dry barley (cow 1021, trial 16) ........ 0.86 gram Mean partial net nitrogen per 100 grams dry casein (cow 1021, 3 trials; and cow 1007, 
4 trials) .10 .5 grams

Casein equivalent of harley: $\frac{0.86}{10.5} \times 100=8.2$ grams per 100 grams dry matter. $(100$ grams barley dry matter replaces 8.2 grams casein.)

2. "Nitrogen-free" glucose equivalent:

Partial "nitrogen-free" net energy per 100 grams dry barley (cow 1021, trial 16)

Mean partial net energy per 100 grams glucose (cow 1021, 3 trials; and cow 1007,

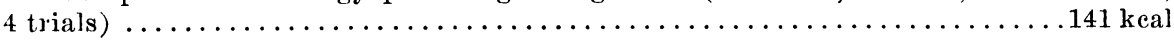

Nitrogen-free glucose equivalent of barley : $\frac{122}{141} \times 100=86$ grams per 100 grams dry matter.

3. Casein-glucose equivalent:

100 grams barley dry matter replaces 8.2 grams casein and 86 grams glucose.

TABLE 8

Casein-Glucose Equivaiment of Barley

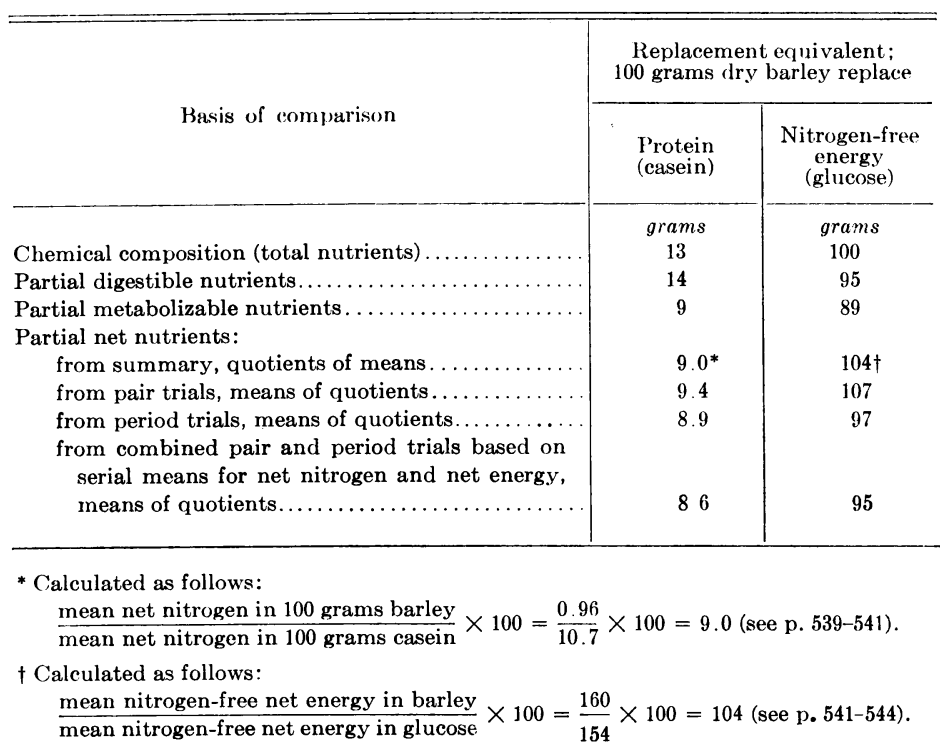

The results of the 2-week trials of the first series are based on seven reference trials; those of the 3 -week trials of the second series on two reference trials. The simple mean of four quotients amounts to $8.6 \pm 2.0$ grams of casein equivalent for 100 grams of dry barley. The four nitrogen-free glucose equivalents obtained by the same method of calculation average $95 \pm 8$ grams glucose equivalent for the nitrogen-free energy in 100 grams of dry barley.

Casein-Glucose Equivalent of Barley.--Table 8 compares the casein-glucose equivalent of barley as calculated on the basis of total, digestible, metabolizable, and net nutrients. The determination of nitrogen content and heat of combustion alone would have led to the same glucose equivalent of barley as the determination of the net energy in our respiration trials. The casein value of barley is higher when based on total or on digestible nitrogen than when 
based on net nitrogen ; but, in view of the great variability of our results on nitrogen utilization, the difference cannot be regarded as significant.

In our dairy rations 100 grams of dry matter of barley replaced, on the average of both series of respiration trials, 9 grams of casein and 100 grams of glucose. This casein-glucose equivalent is considerably higher than that obtained in the first series alone and published as preliminary results (Kleiber 1940 , table 2).

\section{DISCUSSION}

Net Energy vs. Metabolizable Energy.-The nitrogen-free glucose equivalent of barley calculated on the basis of digestible nutrients does not differ from that based on net energy. This result is in line with Kellner's (1919) observation that the "Wertigkeit" of grain was 100 per cent, which means that the utilization of digestible energy from grain for fattening adult steers is equal to the utilization of digestible energy from a pure substance such as starch. To test the significance of feed evaluation according to net energy as compared with metabolizable or digested energy, we should have to measure the partial replacement equivalents or roughages as additions to the maintenance ration, replacing casein and glucose. If we should then find that the casein-glucose equivalent of 1 pound total digestible nutrients in a roughage is significantly lower than that of 1 pound in barley, our finding would justify the evaluation of feeds in terms of net energy rather than digestible energy. This would be true independently of the explanation for the result. Some may attribute to the roughage a higher "work of digestion and absorption," using Zuntz's ideas; or in addition a greater fermentation, as Kellner suggests. Others, abandoning a physiological explanation, may accept Axelsson's (1939) recent merely mathematical concept of a disturbance of the nutritive balance by addition of roughage to the basic food. Regardless of the theory preferred, the fact would remain that 1 pound of total digestible nutrients in roughage added to a given basic ration would produce less milk or body substance than 1 pound in concentrates added to the same basic ration. Our trials thus far have not contributed to the question of "Wertigkeit" of roughage.

The net energy in Sudan hay was 75 per cent of the metabolizable energy.

The net energy in glucose was $\frac{147}{283} \times 100=52$ per cent, that of barley $\frac{160}{291} \times 100=55$ per cent of the metabolizable energy. This fact indicates that

the efficiency of the metabolizable energy in hay for maintenance was greater than the partial efficiency of glucose or barley for lactation.

Paired Respiration Trials vs. Scandinavian Group Trials.-Aside from some results on protein and energy utilization in Sudan hay for maintaining dry cows, and on partial utilization of protein and energy from casein, glucose, and barley for lactation, our trials yield a basis for appraising the relative merits of paired feeding trials with measurement of the nitrogen and carbon balances, as compared with group trials using body weights as criteria for change in body substance.

The coefficient of variation of the net energy in Sudan hay for maintenance is only \pm 8 per cent for both series of our respiration trials. 
The partial net energy in glucose, however, is over three times as variable: it has a standard deviation of \pm 29 per cent of the mean. The coefficient of variation for one measurement of the net energy of barley has the same magnitude-namely, \pm 24 per cent of the mean.

In thirteen trials carried out by Kellner and Köhler (1900) on adult steers, the standard deviation of the "Ansatzkoeffizienten" of starch (net energy in per cent of metabolizable energy) may be calculated to be \pm 11 per cent of the mean coefficient. This comparison indeed indicates that trials on food utilization for lactation are subjected to greater variability than trials on food utilization by adult steers when equal numbers of animals and equal duration of the experiment are compared. In growing steers, however, according to results of Mitchell, Hamilton, and Haines (1940), the variability of glucose utilization was as great as that with our lactating cows.

Considering the great variability of the results of our respiration trials on lactating cows, one may ask under what conditions an ordinary Scandinavian group trial with dairy cows could yield results as reliable as those obtained with paired feeding in the respiration chamber.

As discussed before (p. 515), one major error inherent in the ordinary Scandinavian group trial is the estimation of changes in body substance from the changes in body weight. Lush and his co-workers (1928) analyzed the variance in the results of weighing cattle. From the total variance they deducted the partial variance caused by trends in changing weight with time and by differences between individuals; thus they derived a remainder variance that led to a standard error of weight. The mean of this standard error calculated for their data on 238 cows amounts to $\pm(5.5 \pm 0.4) \mathrm{kg}$. This is very close to a standard deviation of $\pm 5.9 \mathrm{~kg}$ which Kleiber (1929) has calculated from Kellner's and Köhler's (1900) protocols for steers.

With a standard error of $\pm 5.5 \mathrm{~kg}$ for one weighing, the standard error of the gain in weight, which is the difference between two weights, would be $\pm 5.5 \sqrt{2}= \pm 7.8 \mathrm{~kg}$; and the standard error of the mean gain in weight of six cows would be $\frac{ \pm 7.8}{\sqrt{6}}= \pm 3.2 \mathrm{~kg}$. The difference between the mean gains in weight of two groups of six cows would therefore be subjected to a standard error of $\pm 3.2 \sqrt{2}=+4.5 \mathrm{~kg}$. In terms of energy this error would amount to a maximum $4.5 \times 9,500= \pm 43,000 \mathrm{kcal}$, assuming the weight error to involve pure fat only.

The milk energy obtained in 10 months from forty-two Jersey and twentyfour Holstein cows at this station (Kleiber and Mead, 1941) averaged 4 million kilocalories per cow. This is $400,000 \mathrm{kcal}$ per month. If, then, one ran a Scandinavian group trial with twelve cows (behaving like those discussed above) for only 1 month, the maximum effect of the weight error would amount to only \pm 11 per cent of the result. If the uncertainty of body weight were the only source of error, then the reliability of such a trial of only 1 month's duration would just equal that of one of Kellner's respiration trials with steers and would greatly surpass that of our paired respiration trials with cows. The maximum effect of the weight error of a 6 months' group trial would, according to these figures, amount to only \pm 2 per cent of the result. 
This of course applies only to a trial in which the trend in change of weight is kept small; otherwise such a trend would introduce an additional error resulting from the uncertainty of the energy equivalent of change in weight. A lengthy group trial can, however, be so conducted that the trend in weight change is negligible.

Effect of Basic Food on Reliability of Results, and Advantage of Reference substance.-From four paired trials we can conclude that the "nitrogenfree" net energy for lactation per 100 grams of dry matter is $164 \pm 30$ kcal for glucose and $160 \pm 19 \mathrm{kcal}$ for barley. If the results on glucose were independent of those on barley, the mean difference would be $4 \pm 36$.

The mean of the four differences-namely, net energy in barley minus net energy in glucose, each obtained from a pair trial-amounts, however, to $4 \pm 18 \mathrm{kcal}$. The method of pair trials in this case doubled the reliability of the result, as compared with the calculation from single trials, because net energy of barley and glucose within each trial are correlated." One major source of error, whose effect may be greatly reduced by the pair trial, is probably the basic part of the ration, especially the composition and condition of the Sudan hay. The error might have been reduced to one half by use of a less variable maintenance food for the entire investigation-for example, a mixture of Sudan hay and molasses beet pulp ground, prepared in pellet form, and kept in cans. (Compare p. 520.)

Even with an ideal basic food, however, the use of a reference substance would still be preferable to the measurements of absolute values such as net energy, because the effect of other variables may be also reduced by the use of the reference substance. (Compare p. 516.) Until conditions of dairy feeding ean be much better defined and standardized than at present, the use of a reference substance for comparisons is a useful tool in measuring food values.

The net energy for lactation in barley was lowest in the low-protein ration. The difference between the result on that ration and the mean of the other results cannot be considered significant, because of the great variability. It is, however, in line with conclusions drawn from earlier work, especially by Möllgaard $(1923,1929)$; and it tends to support the advantage of using a reference substance with an adjustable protein:energy ratio such as casein and glucose.

The advantage of using these two relatively pure substances as reference substance is obvious even though commercial casein itself is pretty far from having a constant composition. Our trials showed, however, that the advantages of using semipure compounds as reference substance may be outweighed by the effect on the animal's appetite. Palatability seems to be more important in the performance of high-producing dairy cows than in that of fattening steers. Kellner (1900) fattened steers fairly well with rations containing great amounts of pure starch or oil or wheat gluten or even cellulose. We, on the other hand, could not maintain a high lactation in our cows when casein and glucose were substituted for grain and cottonseed meal, even though we trained the cows for months to that diet.

21 The eorrelation coefficient amounts to 0.82 ; its significance is, however, doubtful, since it is based on only four pairs of results. 
Until we can make casein glucose rations nearly as palatable as ordinary feeds, we must conclude that a mixture of a "natural" high-protein and a "natural" low-protein feed, such as cottonseed meal and barley, would probably be a more suitable reference substance for measuring food values with dairy cows than is our mixture of casein and glucose. To obtain barley and cottonseed meal or similar feeds in well-enough-defined composition and condition might be easier than to train high-producing dairy cows sufficiently to rasein and glucose.

Cous vs. Steers for Measuring Food Values.-The net energy for lactation in glucose measured in a 3 weeks' respiration trial is about three times as variable as the net energy of starch for fattening measured in a similar trial. ${ }^{92}$ This result does not, however, necessitate Möllgaard's apparent conclusion (1927) — namely, that food values for dairy cows should be measured on steers. If the great variability shown in our trials is inherent in food utilization by cows, then the application of any food value to dairy cows would anyway be subjected to an error corresponding to this variability. Apply ing results from fattening steers to dairy cows would not decrease this randorn error. Such procedure would, on the contrary, superimpose a systematical error, which originates from the uncertainty of applying the efficiency of food utilization for depositing body fat to a process as different from fattening as is lactation.

For practical feeding trials, dairy cows have a decided advantage. The product of steers in such trials is measured as increase in body weight; and a great source of error, no matter how carefully the trials are conducted, is the interpretation of the increase in weight as increase in energy of body substance. In practical trials with dairy cows, on the contrary, changes in body weight play a minor role. If the trials are carefully conducted, the product (milk) can be measured and analyzed with an accuracy that makes an error from this source negligible compared with other errors of the trial.

There remains a possible source of error inherent in these trials, whether they are conducted with groups in the barn or with pairs in the respiration chamber. Conceivably, cows fed rations higher than their requirement for maintenance and lactation may increase their metabolic rate and thus burn up the extra food taken, instead of using it for gains in body fat and body protein. In this case the added food would seem to have no nutritive value. Whether such a possibility is to be feared more in cows than in steers is not known at present. According to Möllgaard (1923), cows with a reduced milk flow but a continued intake of food at the production level readily gain body substance, and this fattening effect in cows is reliable enough so that "production equivalents" (net energy for fattening per 1,000 kcal of net energy for milk production) can be based on his measurements.

${ }^{22}$ The variability of the net energy of glucose measured on growing steers by Mitchell, Hamilton, and Haines (1940) is, however, just as great as the variability of net energy in glucose measured in our lactation trials. The net energy per 100 grams of glucose determined by Mitchell and his co-workers $(1940$, p. 859$)$ is subject to a coefficient of variation of \pm 39 per cent of the mean. The corresponding coefficient of variation for the net energy of glucose in our lactation trials amounts to \pm 29 per cent of the mean. 


\section{CONCLUSIONS}

In view of these results, there seems to be no justification for discarding the cows in measuring feed values and particularly no justification for the idea that food values for dairy cows could be measured only with steers.

Through the use of a standardized basic food and a standardized multiple reference substance adjustable to the protein:energy ratio of the feeds to be tested, the Scandinavian group trial should become one of the best methods for measuring food values, especially food values for milk production.

To know for each of the cows used in such group trials the complete carbon and nitrogen balance would be ideal. To run the group trial in twelve respiration chambers, however, not only would be a considerable economic burden, but might involve technical disadvantages because it might introduce artificial conditions. The best improvement over the Scandinavian group trial (with estimation of body gain from body weight) would be the conduction of this trial in two respiration chambers, each housing a group of six cows. That would permit the conduction of the trial under fairly natural conditions and would furnish a reliable basis for measuring the body gains or losses, at least for each group as a whole. This for the measurement of food utilization may be all one needs, whereas for much metabolic research the individual respiration trial remains the only satisfactory procedure.

\section{SUMMARY}

In evaluating dairy feeds, one must know how much of one feed replaces a given amount of another as part of a well-balanced dairy ration. This figure is designated as partial replacement equivalent.

The present sources for deriving feed equivalents, such as total digestible nutrients, net energy, starch values, and Scandinavian feed units, lead to very different results and are all open to criticism.

This paper reports an investigation of the possibilities of obtaining better partial replacement equivalents of dairy feeds.

The Scandinavian group trial is at present the most reliable method for measuring replacement equivalents, because the conditions under which these trials are carried out resemble most nearly the conditions under which the results are applied; these trials measure the replacement equivalent of a feed for barley.

The replacement of a single constant reference substance such as barley may lead, however, to a change in the protein:energy ratio, which in turn may affect the efficiency of energy utilization in a dairy ration. The expression of food value in one figure, such as the starch or barley equivalent, moreover, neglects the fact that protein and energy have essentially different physiological functions, and that protein cannot be replaced by nitrogen-free sources of energy.

In paired feeding trials on dairy cows in a double respiration chamber, we measured the daily carbon and nitrogen balances as bases for calculating the changes in body protein and body fat content of the cows. These figures, in addition to protein and energy yield in the milk, are necessary for calculating food utilization. 
The daily fasting heat production, measured on two pregnant cows during the fourth and fifth day of fast, amounted to $86 \pm 3 \mathrm{kcal}$ per day per $\mathrm{kg}^{3 / 4}$, which is about 20 per cent above the level reported for dry empty cows and which, for a 1,000-pound cow, amounts to 8,400 kcal.

The lactation rations consisted of a constant part, fed at the maintenance level, and a variable or exchangeable part completing the ration.

Sudan hay was used as the constant part of the rations. The nutritive content of this hay for maintenance, together with the maintenance requirement of dry cows, was measured in fourteen 2-week respiration trials (seven trials with two cows each).

The protein in Sudan hay was 62 per cent digestible; and the food energy was 67 per cent digestible.

An average of 3.5 grams of methane was produced per 100 grams of carbohydrates in the hay, which contained, on the average of seven trials, $222 \mathrm{kcal}$ of metabolizable energy per 100 grams of dry matter.

The total nitrogen in Sudan hay was utilized to 25 per cent; the digestible nitrogen to 41 per cent. The energy utilization amounted to 59 per cent of the digestible energy. Dry Sudan hay contained, per 100 grams, 3.3 grams of net protein and $167 \mathrm{kcal}$ of net energy for maintenance.

$\Lambda$ 1,000-pound cow would require daily 7 pounds of the Sudan hay to meet her protein requirement, but, 14 pounds of the same hay to maintain energy equilibrium.

In four lactation trials of 3 weeks' duration and five of 2 weeks' duration, a mixture of casein and glucose was added to the Sudan hay to complete a balanced ration containing a well-defined reference substance. In two trials of 3 weeks' duration and three trials of 2 weeks' duration, the glucose and part of the casein were replaced by barley, so that the level of hay remained the same and the protein : energy ratio of the entire ration also was unchanged.

Partial effects of feeds added to the Sudan hay are defined as the changes in the results between hay alone and hay with added feeds during lactation. The partial digestibility of nitrogen in casein amounted to only 65 per cent, probably because glucose depresses the digestibility of hay protein. The partial digestibility of energy in glucose averaged 85 per cent. In barley the nitrogen had a partial digestibility of 72 per cent; the energy a partial digestibility of 77 per cent.

The partial methane production of glucose amounted to 1.9 grams of methane per 100 grams of carbohydrates; that of barley, to 3.8 grams.

Casein contained 11 per cent partial net nitrogen; barley 1 per cent.

The partial net energy in glucose averaged 154 keal per 100 grams of dry matter; that in barley, 194 kcal.

The casein-glucose equivalent of barley has been calculated from our results, arranged as pair trials (comparing simultaneous results on two similar cows), as period trials (comparing the results for each cow at different periods), and as a combination of the two methods (comparing the results of the barley trial with each cow with the serial mean of all results of both cows on the reference substance). On the average, 100 grams of barley will replace 9 grams of casein and 100 grams of glucose. This statement means that the "nitrogen-free" energy in 100 grams of barley is equivalent to 100 grams of glucose. 
The coefficient of variation of net energy in Sudan hay for maintenance in each of the two series of experiments amounts to \pm 8 per cent. The results on the partial nutritive effects of casein, glucose, and barley as parts of dairy rations are, however, much more variable. The coefficient of variation for the partial net energy of glucose is \pm 29 per cent; that of barley \pm 24 per cent.

The maximum partial error resulting from the uncertainties of body weight in a well-conducted Scandinavian group trial with twelve cows for 1 month may be estimated as \pm 11 per cent of the mean result. This is less than half the error observed in our paired respiration trials of 2 and 3 weeks' duration. Since the uncertainty of body weight as a criterion for body substance is to be regarded as the major reason for preferring a respiration trial over ai ordinary group trial, we must conclude from our results that a well-conducted Scandinavian group trial is at least equal to, and probably superior to, a pair trial in a respiration chamber for measuring replacement equivalents of feeds. Aside from the variability of the results, the group trial has the further advantage of approaching more closely the conditions under which the measured replacement equivalents are to be applied.

The advantage of using semipure materials such as casein and glucose as reference substance may, according to our trials, be overcompensated by the decrease in appetite resulting from these feeds, which was the major difficulty in our experiments, and which led to a loss in body weight as well as an abnormal decrease in the rate of milk production.

Until the palatability of casein and glucose or a similar semipure reference substance can be considerably increased, a more "natural" substitute reference substance, consisting of a protein-low and protein-high feed, such as a mixture of cottonseed meal and barley, may be preferable as a standard in group trials for measuring replacement equivalents of dairy feeds.

\section{ACKNOWLEDGMENT}

For valuable help in these trials thanks are due particularly to $\Lambda$. H. Smith and W. Pearlson, who assisted in preparing the feeds, performed the gas analyses, and helped to calculate the results; to H. Goss, J. Soderberg, and R. W. Caldwell for analyses of feeds and excreta; to F. Greeley, who greatly improved the machine of the respiration apparatus; to $\mathrm{H}$. Hall, for maintaining the apparatus in proper condition ; to $\mathrm{H}$. Lucas, who carried out extensive preliminary trials that led to the selection of the feeds; and to L. Harwood and C. Fisher, for valuable observations while caring for the experimental animals. With special gratitude we acknowledge that H. H. Mitchell has studied our manuscript; his constructive criticism led to the inclusion of points that we had overlooked, and he helped to clarify statements that might otherwise have been misinterpreted. 


\section{LITERATURE CITED}

ARMSBy, H. P.

1922. The nutrition of farm animals. 743 p. (See specifically p. 271.) The Macmillan Company, New York, N. Y.

Armsbi, H. P., and J. A. Fries.

1915. Net energy values of feeding stuffs for cattle. Jour. Agr. Res. 3:435-91.

1916. Net energy values for ruminants. Pennsylvania Agr. Exp. Sta. Bul. 142:19.

1918. Net energy values of alfalfa hay and of starch. Jour. Agr. Res. 15:269-86.

Axmlsson, J.

1939. Die wissenschaftliche Grundlage des Stärkewerts. Tierernährung 11(2):176-205.

Bratzler, J. W., and E. B. Forbes.

1940. The estimation of methane production by cattle. Jour. Nutr. 19:611-13.

Brody, S., and R. C. Procter.

1.932. Relation between basal metabolism and mature body weight in different species of mammals and birds. Univ. Missouri Col. Agr. Res. Bul. 166:89-101.

Brody, S., R. C. Procter, and U. S. Ashworth.

1934. Basal metabolism, endogenous nitrogen, creatinine and neutral sulfur excretions as functions of body weight. Univ. Missouri Col. Agr. Res. Bul. 220:1-40.

Carpenter, T. M.

1940. The combustion of carbohydrates in man after ingestion of common foods. Jour. Nutr. 19:423-35.

Forbes, E. B.

1932. Net energy of completely balanced nutriment as a measure of nutritive value of rations and of nutritive requirements of animals. Amer. Soc. Anim. Prod. Proc. 1932:38.

Forbes, E. B., M. Kriss, and W. W. Braman.

1927. The computed as compared with the directly observed fasting katabolism of cattle as a measure of the maintenance requirement of energy. Jour. Agr. Res. 34(2): $167-79$.

Forbes, E. B., R. W. Swift, A. Black, and O. J. Kahlenberg.

1935. The utilization of energy-producing nutriment and protein as affected by individual nutrient deficiencies. III : The effects of the plane of protein intake. Jour. Nutr. 10:461-79.

Forbes, E. B., and R. W. Swirt, and Collaborators.

1941. The minimum base value of heat production in animals. Pennsylvania Agr. Exp. Sta. Bul. 415:1-26.

Guilbert, H. R., and G. H. Hart.

1935. Minimum vitamin-A requirements with particular reference to cattle. Jour. Nutr. $10: 409-27$.

HAMILTON, T. S.

1935. Factors affecting the thermogenic action of food; report of the conference on energy metabolism. National Research Council 1935:26-49.

1942. The effect of added glucose upon the digestibility of protein and of fibre in rations for sheep. Jour. Nutr. 23:101-10.

HANSSON, $\mathrm{N}$.

1914. Futtereinheiten und Stärkewert. Fühlings landwirtschaftliche Zeitung 63(2):41-53.

1923. Fodermedlens nettoenergivärde vid Mjölkproduction Beretning om Nordiske Jordbrugsforskeres Kongres i Göteborg 1923:83-94. (See specifically p. 91.)

1928. Husdjurens Utfodring. 244 p. (See specifically p. 228.) E. Fritze, Stockholm.

HoPKINS, J. A.

1940. Elements of farm management. 489 p. (See specifically p. 258.) Prentice-Hall, New York, N. Y.

KeLINAR, O.

1919. Die Ernährung der landwirtschaftlichen Nutztiere. 8th ed. 667 p. (See specifically p. 96.) Paul Parey, Berlin.

Kellner, O., and A. KöHLER.

1900. Untersuchungen über den Stoff und Energiewechsel des erwachsenen Rindes bei Erhaltungs und Produktionsfutter. Landw. Vers. Sta. 53:1-474. (See p. 450.) 
Kellner, O., A. Köhler, F. Barnstein, W. Zeilstorff, L. Hartung, and H. Lürig.

1896. Untersuchungen über den Stoff- und Energieumsatz volljähriger Ochsen bei Erhaltungsfutter. Landw. Vers. Sta. 47:273-331. (See specifically p. 287.)

KLEIBER, M.

1929. Milchwert und Stärkewert. Fortschr. der Landw. $4: 33$.

1932. Body size and metabolism. Hilgardia 6:315-53.

1933. Contribution to the method of gas analysis for respiration trials. Jour. Biol. Chem. $101: 583-94$.

1933. Tiergrösse und Futterverwertung. Tierernährung $5: 1-12$.

1935. The California apparatus for respiration trials with large animals. Hilgardia $9: 1-70$.

1936. Problems involved in breeding for efficiency of food utilization. Amer. Soc. Anim. Prod. Proc. $1936: 247-58$.

1938. Food value and metabolic unit of body size. Amer. Soc. Anim. Prod. Proc. 1938:341.

1940. The measurement of partial nutritive equivalents. Amer. Soc. Anim. Prod. Proc. $1940: 332-39$.

Kleiber, M., and S. W. MEAD.

1941. Body size and milk production. Jour. Dairy Sci. 24:127-34.

KRISS, M.

1930. Quantitative relations of the dry matter of the food consumed, the heat production, the gaseous outgo, and the insensible loss in body weight of cattle. Jour. Agr. Res. $40: 283-95$.

1931. A comparison of feeding standards for dairy cows with especial reference to energy requirements. Jour. Nutr. 4:141-61. (See specifically p. 156.)

l.EWIS, G. N., and M. RANDALL.

1923. Thermodynamies and the free energy of chemical substancess. 1st ed. MeGraw Hill Book Company, New York and London. 653 p.

Lush, J. L., F. W. Christensen, C. V. Wilson, and W. H. Black.

1928. The accuracy of cattle weights. Jour. Agr. Res. 36:551-80.

MAYER, A.

1925. Agrikulturchemie. Vol. 4, 2 d ed. 423 p. (See specifically p. 194.) Carl Winter, Heidelberg, Germany.

Maynard, L. A.

1937. Animal nutrition. 483 p. McGraw-Hill Book Company, New York and London.

MeIGs, E. B.

1925. The energy requirement of dairy cows. II: Is net energy or metabolizable energy the more useful index for practical purposes? Jour. Dairy Sci. 8:523-36.

Mendel, L. B., and M. S. Fine.

1912. Studies in nutrition V. The utilization of the proteins of cotton seed. Jour. Biol. Chem. 11:1-26.

Mitchell, H. H.

1922. The net protein value of feeds and food materials. Amer. Soc. Anim. Prod. Proc. $1922: 55-58$.

1926. The determination of the protein requirements of animals and of the protein values of farm feeds and rations. Natl. Res. Council Bul. 55:1-44.

1934. Balanced diets, net energy values and specific dynamic effects. Science 80:558-61.

1937. The importance of the relations between energy, protein, and minerals in measuring the nutritive value of feeds and rations. Amer. Soc. Animal Prod. Proc. 1937:29-4:.

Mitchell, H. H., and G. G. Carman.

1924. The biological value for maintenance and growth of the proteins of whole wheat, eggs, and pork. Jour. Biol. Chem. $60: 613-20$.

Mitchell, H. H., T. S. Hamilton, and W. T. Haines.

1940. The utilization by calves of energy in rations containing different percentages of protein and in glucose supplements. Jour. Agr. Research 61:847-64.

Mitchell, H. H., and V. Villegas.

1923. The nutritive value of the proteins of coconut meal, soy beans, rice bran, and corn. Jour. Dairy Sci. 6:222-36. 
MöllgaARd, H.

1923. New views regarding the scientific feeding of dairy cattle. Experiments in connection with the problem of the requirements of energy and matter for milk production and investigations into the question of the possibility of a general unit for measuring the productive value of feeding stuffs. Report, International Congress for the Production of the Bovine Species. The Hague. 1923 (sect. 1b):272-89.

1927. Wert der Futtermittel bei der Milcherzeugung und rationelle Fütterung des Milchviehes. Mitteil. Deutsch. Landw. Gesell. 24:621-33.

1929. Fütterungslehre des Milchviehs. 246 p. (See specifically p. 165, 205.) M. and H. Schaper, Hanover, Germany.

1931. Grundzüge der Ernährungsphysiologie der Haustiere. (German translation of the second Danish edition, by E. Bass.) 395 p. (See specifically p. 327.) Paul Parey, Berlin.

MorRison, F. B.

1936. Feeds and feeding. 20th ed. 1050 p. (See specifically p. 978.) Morrison, Ithaca, N.Y.

Peterson, Wm. E.

1932. A formula for evaluating feeds on the basis of digestible nutrients. Jour. Dairy Sei. $15: 293-97$.

RICHMOND, H. D.

1920. Dairy chemistry. $3 d$ ed. 490 p. (See specifically p. 50, 457.) Charles Griffin, London.

SCHNEIDEWIND, W., D. Meyer, and W. GRöBler.

1910. Fütterungsversuche über die Wirkung der verdaulichen Nährstoffe im Rauhfutter und Kraftfutter. Deut. Landw. Presse $37: 1123-24$.

Smuts, D. B.

1935. The relation between the basal metabolism and the endogenous nitrogen metabolism with particular reference to the estimation of the maintenance requirement of protein. Jour. Nutr. $9: 403-33$.

Soskins, S.

1941. The blood sugar. Physiol. Rev. 21:140-93.

Soskins, S., and R. Levine.

1937. A relationship between the blood sugar level and the rate of sugar utilization affecting the theories of diabetes. Amer. Jour. Physiol. 102:761-70. (See specifically $p .768$.

Terroine, E. F., and H. Sorg-Matter.

1927. Loi quantitative de la dépense azotée minima des homéothermes, validité interspecifique. Arch. Internatl. de Physiol. 29:121.

TIPPETT, L. H. C.

1931. The method of statistics. 222 p. (See specifically p. 57.) Williams and Norgate, London.

Watson, C. J., J. A. Campbell, W. M. Davidson, C. H. Robinson, and G. W. Muir.

1939. Associative digestibility of grains: barley, oats, and oileake. Sci. Agr. 20(4): 238-53.

WINCHESTER, C. F.

1938. Mechanized gas analysis apparatus. Rev. Sci. Instruments 9:134-38.

WOLFF, E.

1895. Farmfoods. (English translation from Landwirtschaftliche Fütterungslehre, 6th ed., by H. H. Cousins; 1st ed. 1874.) 365 p. Gurney and Jackson, London.

WolfF, E., [?] Sieglin, C. Kreuzhage, and C. Riess.

1888. Grundlagen für die rationelle Fütterung des Pferdes. Biedermann's Zentbl. f. Agr. Chem. 17:241-52; 299-314.

Woodman, H. E., and R. E. Evans.

1938. The mechanism in cellulose digestion in the ruminant organism. IV. Further observations from in vitro studies of the behavior of rumen bacteria and their bearing on the problem of the nutritive value of cellulose. Jour. Agr. Sci. 28:43-63.

Zuntz, N., R. von DER Heide, and W. Klein, with MARKoff, Dschandieri, and DJakoff. 1913. Zum Studium der Respiration und des Stoffwechsels der Wiederkäuer. Landw. Vers. Sta. 79-80:781-814. 
APPENDIX TABLES 


\section{KEY TO APPENDIX TABLE A}

Each of the 32 sections of Appendix Table A represents the mean results of ten to fifteen 24-hour respiration trials. The superseript letters in the table constitute a guide to the sequence of the calculations. The meanings of these letters are as follows:

a Energy in urine $=(\mathrm{C}$ in urine $) \times 10$

${ }^{1} \mathrm{C}$ in methane $=$ liters $\mathrm{CH}_{4} \times 0.536$

c Energy in methane $=$ liters $\mathrm{CH}_{4} \times 9.5$.

" $\mathrm{C}$ in $\mathrm{CO}_{2}=$ liters $\mathrm{CO}_{2} \times 0.536$

${ }^{\circ} \mathrm{C}$ in gained protein $=\mathrm{N}$ gained $\times 3.25$

${ }^{\mathrm{P}}$ Energy in gained protein $=\mathrm{N}$ gained $\times 35.615$

${ }^{2} \mathrm{C}$ in gained $\mathrm{fat}=$ total $\mathrm{C}$ gained minus $\mathrm{C}$ in gained protein

${ }^{\mathrm{h}}$ Energy in gained fat $=\mathrm{C}$ in gained fat $\times 12.42$

' Energy in gained body substance = energy in gained fat plus energy in gained protein

${ }^{k}$ Heat production $=$ katabolizable energy minus energy in gained body substance

The halves of a pair trial (no. 3) are shown on the next page. In the pages that follow, the halves of the various pair trials are placed side by side. 
APPENDIX TABLE A

Avfrage Daily Nitrogen, Carbon, and Energy Balance*

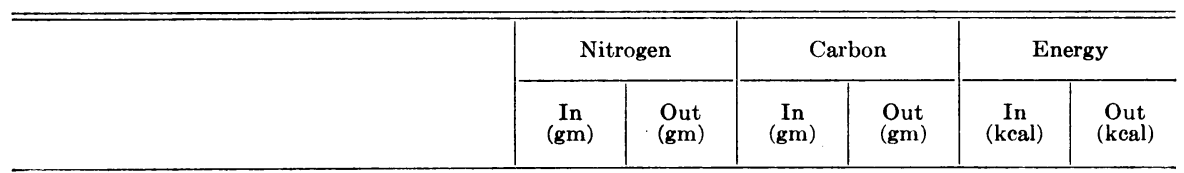

Trial 3, north chamber; Aug. 7-19, 1939; cow no. 494, weight $467 \mathrm{~kg}$; W3/4 $=100 \mathrm{~kg}^{3 / 4}$

\begin{tabular}{|c|c|c|c|c|c|c|}
\hline Feed: dry Sudan hay, 5,270 gm $\ldots \ldots \ldots \ldots \ldots$ & 103.2 & $\cdots$ & 2,222 & $\ldots \ldots$ & 22,140 & \\
\hline 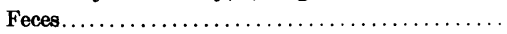 & $\ldots$ & 39.3 & $\ldots \ldots$ & 693 & $\ldots \ldots$ & 7,250 \\
\hline Digested nitrogen, carbon, or energy . . . . . . & 63.9 & $\ldots$ & 1,529 & $\ldots \ldots$ & 14,890 & $\ldots \ldots$ \\
\hline Urine $\ldots \ldots \ldots \ldots \ldots \ldots \ldots \ldots \ldots \ldots \ldots$ & $\ldots$ & 60.0 & $\ldots \ldots$ & 143 & $\ldots \ldots$ & $1,430^{\mathrm{a}}$ \\
\hline Methane (191 liters) $\ldots \ldots \ldots \ldots \ldots \ldots \ldots \ldots \ldots$ & $\ldots$ & $\ldots$ & $\ldots \ldots$ & $102^{b}$ & $\ldots \ldots$ & $1,820^{\circ}$ \\
\hline Metabolizable nitrogen, carbon, or energy . . . . & 3.9 & $\cdots$ & 1,284 & $\ldots \ldots$ & 11,640 & $\ldots \ldots$ \\
\hline Heat (respiration, 2,481 liters $\left.\mathrm{CO}_{2}\right) \ldots \ldots \ldots \ldots$ & $\ldots$ & $\cdots$ & $\ldots \ldots$ & $1,330^{\mathrm{d}}$ & & $12,230 \mathrm{k}$ \\
\hline Gain in body substance $\ldots \ldots \ldots \ldots \ldots \ldots$ & 3.9 & $\ldots$ & $\ldots \ldots$ & -46 & $\ldots \ldots$ & $-590^{i}$ \\
\hline Gain in body protein $(N$ gain $\times 6.25) \ldots \ldots \ldots$ & 3.9 & $\ldots$ & $13^{\mathrm{e}}$ & $\ldots$ & $140^{f}$ & $\ldots \ldots$ \\
\hline Gain in body fat $(\mathrm{C}$ in gained fat $\times 1.31) \ldots$ & $\ldots$ & $\ldots$ & & $-59 \mathrm{~g}$ & & $-730^{\mathrm{h}}$ \\
\hline
\end{tabular}

Trial 3, south chamber; Aug. 7-19, 1939; cow no. 1003, weight $493 \mathrm{~kg}$; W3/4 $=105 \mathrm{~kg}^{3 / 4}$

\begin{tabular}{|c|c|c|c|c|c|c|}
\hline Feed: dry Sudan hay, $5,270 \mathrm{gm} \ldots \ldots \ldots \ldots \ldots$ & 103.2 & $\ldots$ & 2,222 & $\ldots \ldots$ & 22,140 & $\ldots \ldots$ \\
\hline 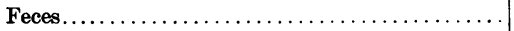 & $\ldots$ & 34.8 & $\ldots \ldots$ & 665 & $\ldots \ldots$ & 6,900 \\
\hline Digested nitrogen, carbon, or energy . . . . . . . & 68.4 & $\ldots$ & 1,557 & $\ldots \ldots$ & 15,240 & $\ldots \ldots$ \\
\hline 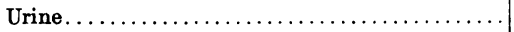 & $\ldots$ & 66.5 & $\ldots \ldots$ & 155 & $\ldots \ldots$ & $1,550 \mathrm{a}$ \\
\hline Methane $(184$ liters $) \ldots \ldots \ldots \ldots \ldots \ldots \ldots \ldots$ & $\ldots$ & $\ldots$ & $\ldots \ldots$ & $99 \mathrm{~b}$ & $\ldots \ldots$ & $1.750^{\mathrm{e}}$ \\
\hline Metabolizable nitrogen, carbon, or energy .... & 1.9 & $\ldots$ & 1,303 & & 11,940 & $\ldots \ldots$ \\
\hline Heat (respiration, 2,351 liters $\mathrm{CO}_{2}$ ) $\ldots \ldots \ldots \ldots \ldots$ & $\ldots$ & $\ldots$ & $\ldots \ldots$ & $1,260^{d}$ & $\ldots \ldots$ & $11,410^{k}$ \\
\hline Gain in body substance. . . . . . . . . . . . . & 1.9 & $\ldots$ & 43 & $\ldots \ldots$ & $530^{i}$ & $\ldots \ldots$ \\
\hline Gain in body protein $(\mathrm{N}$ gain $\times 6.25) \ldots \ldots \ldots$ & 1.9 & $\ldots$ & $6^{\mathrm{e}}$ & & $70^{f}$ & $\ldots \ldots$ \\
\hline Gain in body fat $(C$ in gained fat $\times 1.31) \ldots \ldots$ & $\ldots$ & $\ldots$ & $37 \mathrm{~g}$ & & $460^{b}$ & $\ldots \ldots$ \\
\hline
\end{tabular}

* Superscript letters are explained in the Key to Appendix Table A, p. 558. 
TABLE A (Continued)

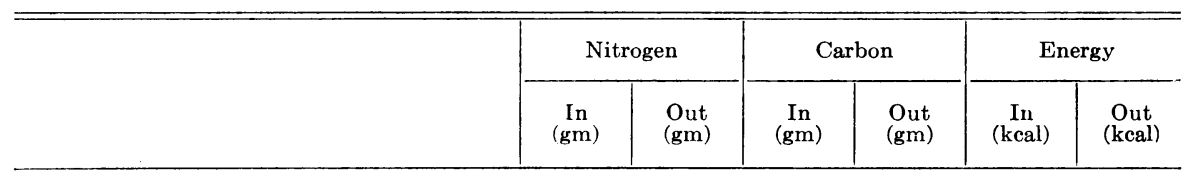

Trial 5, north chamber; Sept. 4-16, 1939; cow no. 494, weight $488 \mathrm{~kg}$; W33/4 $104 \mathrm{~kg}^{3 / 4}$

\begin{tabular}{|c|c|c|c|c|c|c|}
\hline Feed: dry Sudan hay, $4,465 \mathrm{gm} \ldots \ldots \ldots \ldots \ldots$ & 90.1 & $\ldots$ & 1,855 & $\ldots$ & 18,940 & $\ldots \ldots$ \\
\hline 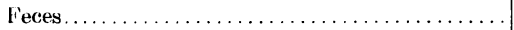 & $\ldots$ & 31.5 & $\ldots \ldots$ & 585 & $\ldots \ldots$ & 6,200 \\
\hline Digested nitrogen, carbon, or energy . . . . . . & 58.6 & $\ldots$ & 1,270 & $\ldots \ldots$ & 12,740 & \\
\hline Methane $(173$ liters $) \ldots \ldots \ldots \ldots \ldots \ldots \ldots$ & $\ldots$ & $\ldots$ & & $93^{\mathrm{b}}$ & & $1,640^{\circ}$ \\
\hline Metabolizable nitrogen, carbon, or energy . . . & 10.1 & & 1,037 & & 9,700 & \\
\hline Heat (respiration, 2,336 liters $\left.\mathrm{CO}_{2}\right) \ldots \ldots \ldots \ldots$ & $\ldots$ & . & & $1,252^{\mathrm{d}}$ & & $12,420^{k}$ \\
\hline Gain in body substance. . . . . . . . . . . & 10.1 & & & -215 & & $-2,720^{\mathrm{i}}$ \\
\hline Gain in body protein $(\mathrm{N}$ gain $\times 6.25) \ldots \ldots \ldots$ & 10.1 & & $33^{e}$ & & $360^{f}$ & $\ldots \ldots$ \\
\hline Gain in body fat $(\mathrm{C}$ in gained fat $\times 1.31) \ldots \ldots$ & $\ldots$ & $\ldots$ & & $-248 \mathrm{~s}$ & $\ldots \ldots$ & $-3,080^{\mathrm{h}}$ \\
\hline
\end{tabular}

Trial 7, north chamber; Oct. 2-13, 1939; cow no. 1009, weight $534 \mathrm{~kg}$; $\mathrm{W}^{3 / 4}=111 \mathrm{~kg}^{3 / 4}$

\begin{tabular}{|c|c|c|c|c|c|c|}
\hline Feed: dry Sudan hay, $5,715 \mathrm{gm} \ldots \ldots \ldots \ldots \ldots$ & 115.3 & $\ldots$ & 2,433 & $\ldots \ldots$ & 23,840 & $\ldots \ldots$ \\
\hline Feces $\ldots \ldots \ldots \ldots \ldots \ldots \ldots \ldots \ldots \ldots$ & $\ldots$ & 43.3 & $\ldots \ldots$ & 718 & $\ldots \ldots$ & 7,310 \\
\hline Digested nitrogen, carbon, or energy ... & 72.0 & $\ldots$ & 1,715 & $\ldots \ldots$ & 16,530 & $\ldots \ldots$ \\
\hline Urine $\ldots \ldots \ldots \ldots \ldots \ldots \ldots \ldots \ldots \ldots \ldots \ldots \ldots$ & $\ldots$ & 66.0 & $\ldots$ & 173 & & $1,730^{\mathrm{s}}$ \\
\hline Methane (200 liters) . . . . . . . . . . . . . . . & $\cdots$ & $\ldots$ & $\ldots \ldots$ & $107 \mathrm{~b}$ & & $1,900^{\circ}$ \\
\hline Metabolizable nitrogen, carbon, or energy.... & 6.0 & $\ldots$ & 1,435 & $\ldots \ldots$ & 12,900 & $\ldots \ldots$ \\
\hline Heat (respiration, 2,710 liters $\mathrm{CO}_{2}$ ) $\ldots \ldots \ldots \ldots$ & $\ldots$ & $\ldots$ & $\cdots$ & $1,453^{d}$ & & $13,160^{\mathrm{k}}$ \\
\hline Gain in body substance............... & 6.0 & $\ldots$ & $\ldots \ldots$ & -18 & $\ldots \ldots$ & $-260^{\mathrm{i}}$ \\
\hline Gain in body protein $(\mathrm{N}$ gain $\times 6.25) \ldots \ldots$ & 6.0 & $\ldots$ & $20^{\Theta}$ & $\ldots \ldots$ & $210^{f}$ & $\ldots \ldots$ \\
\hline Gain in body fat $(\mathrm{C}$ in gained fat $\times 1.31)$ & $\ldots$ & $\ldots$ & $\ldots \ldots$ & $-38 \mathrm{~g}$ & $\ldots \ldots$ & $-470^{b}$ \\
\hline
\end{tabular}

Trial 9, north chamber; Oct. 30-Nov. 11, 1939; cow no. 1009, weight $540 \mathrm{~kg}$. W' $\mathrm{W}^{3 / 4}=112 \mathrm{~kg}^{3 / 4}$

\begin{tabular}{|c|c|c|c|c|c|c|}
\hline Feed: dry Sudan hay, $6,100 \mathrm{gm} \ldots \ldots \ldots \ldots \ldots$ & 123.0 & $\ldots$ & 2,643 & $\ldots \ldots$ & 25,770 & $\ldots \ldots$ \\
\hline 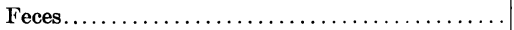 & $\ldots$ & 50.0 & $\ldots \ldots$ & 822 & $\ldots \ldots$ & 8,220 \\
\hline Digested nitrogen, carbon, or energy . . . . . . . & 73.0 & $\ldots$ & 1,821 & $\ldots \ldots$ & 17,550 & $\ldots \ldots$ \\
\hline Methane $(227$ liters) $\ldots \ldots \ldots \ldots \ldots \ldots$ & $\ldots$ & $\ldots$ & & $122^{b}$ & & $2,160^{\circ}$ \\
\hline Metabolizable nitrogen, carbon, or energy . . . . & 12.0 & & 1,530 & & 13,700 & \\
\hline Heat (respiration, 2,837 liters $\mathrm{CO}_{2}$ ) $\ldots \ldots \ldots \ldots$ & $\ldots$ & $\ldots$ & $\ldots \ldots$ & $1,521 \mathrm{~d}$ & $\ldots \ldots$ & $13,640^{k}$ \\
\hline Gain in body substance. . . . . . . . . & 12.0 & & 9 & & $60^{i}$ & $\ldots$ \\
\hline Gain in body protein $(\mathrm{N}$ gain $\times 6.25) \ldots$ & 12.0 & $\ldots$ & $39^{e}$ & $\ldots \ldots$ & $430^{f}$ & $\ldots \ldots$ \\
\hline Gain in body fat $(\mathrm{C}$ in gained fat $\times 1.31) \ldots$ & $\ldots$ & $\cdots$ & & $-30 \mathrm{~g}$ & & $-370^{b}$ \\
\hline
\end{tabular}


TABLE A (Continued)

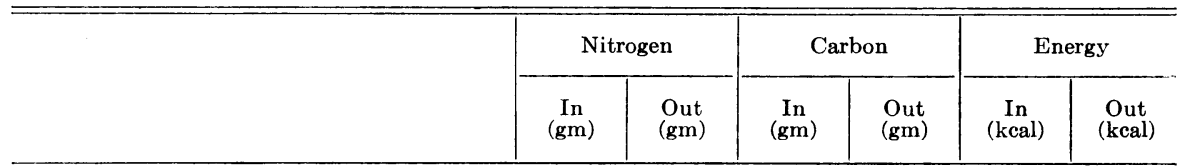

'Trial 5, south chamber; Sept. 4-16, 1939; cow no. 1003, weight $501 \mathrm{~kg}$; W3/4 $=106 \mathrm{~kg}^{3 / 4}$

\begin{tabular}{|c|c|c|c|c|c|c|}
\hline Feed: dry Sudan hay, $4,465 \mathrm{gm} \ldots \ldots \ldots \ldots \ldots$ & 90.1 & $\ldots$ & 1,853 & $\ldots$ & 18,940 & \\
\hline Feces $\ldots \ldots \ldots \ldots \ldots \ldots \ldots \ldots \ldots \ldots$ & $\ldots$ & 31.3 & $\ldots \ldots$ & 597 & $\ldots \ldots$ & 5,990 \\
\hline Digested nitrogen, carbon, or energy . . . . . . & 58.8 & $\ldots$ & 1,258 & $\ldots \ldots$ & 12,950 & $\ldots \ldots$ \\
\hline Methane $(188$ liters $) \ldots \ldots \ldots \ldots \ldots \ldots$ & $\ldots$ & $\ldots$ & & $101^{b}$ & & $1,780^{\mathrm{c}}$ \\
\hline Metabolizable nitrogen, carbon, or energy. & 3.3 & & 1,018 & & 9,780 & \\
\hline Heat (respiration, 2,141 liters $\mathrm{CO}_{2}$ ) $\ldots \ldots \ldots \ldots$ & $\ldots$ & $\ldots$ & & $1,148^{\mathrm{d}}$ & $\ldots \ldots$ & $11,410^{k}$ \\
\hline Gain in body substance . . . . . . . . . . & 3.3 & & & -130 & $\ldots .$. & $-1,630^{\mathrm{i}}$ \\
\hline Gain in body protein $(\mathrm{N}$ gain $\times 6.25) \ldots \ldots$ & 3.3 & & $11 \mathrm{e}$ & $\ldots \ldots$ & $120^{f}$ & \\
\hline Gain in body fat $(\mathrm{C}$ in gained fat $\times 1.31) \ldots \ldots$ & $\ldots$ & & & $-141 \mathrm{~g}$ & & $-1,750^{\mathrm{h}}$ \\
\hline
\end{tabular}

Trial 7, south chamber; Oct. 2-13, 1939; cow no. 1003, weight $500 \mathrm{~kg}$; W3/4 $=106 \mathrm{~kg}^{3 / 4}$

Feed: dry Sudan hay, $5,312 \mathrm{gm}$

Feces.

Digested nitrogen, carbon, or energy

Urine...............

Metabolizable nitrogen, carbon, or energy ...

Milk.

Katabolizable nitrogen, carbon, or energy...

Heat (respiration, 2,364 liters $\left.\mathrm{CO}_{2}\right) \ldots \ldots \ldots \ldots \ldots$

Gain in body substance.

Gain in body protein $(\mathrm{N}$ gain $\times 6.25) \ldots \ldots \ldots$

Gain in body fat $(\mathrm{C}$ in gained fat $\times 1.31) \ldots$.

\begin{tabular}{|c|c|c|c|c|c}
107.2 & $\ldots$ & 2,261 & $\ldots \ldots$ & 22,160 & $\ldots \ldots$ \\
$\ldots$. & 37.7 & $\ldots \ldots$ & 656 & $\ldots \ldots$ & 6,800 \\
69.5 & $\ldots$. & 1,605 & $\ldots \ldots$ & 15,360 & $\ldots \ldots$ \\
$\ldots$ & 60.9 & $\ldots \ldots$ & 168 & $\ldots \ldots$ & $1,680^{\mathrm{a}}$ \\
$\ldots$ & $\ldots$ & $\ldots \ldots$ & $103^{\mathrm{b}}$ & $\ldots \ldots$ & $1,820^{\mathrm{c}}$ \\
8.6 & $\ldots$ & 1,334 & $\ldots \ldots$ & 11,860 & $\ldots \ldots$ \\
$\ldots$ & $\ldots$ & $\ldots \ldots$ & $\ldots \ldots$ & $\ldots \ldots$ & $\ldots \ldots$ \\
8.6 & $\ldots$ & 1,334 & $\ldots \ldots$ & 11,860 & $\ldots \ldots$ \\
$\ldots$ & $\ldots$ & $\ldots \ldots$. & $1,267^{\mathrm{d}}$ & $\ldots \ldots$ & $11,070^{\mathrm{k}}$ \\
8.6 & $\ldots$ & 67 & $\ldots \ldots$ & $790^{\mathrm{i}}$ & $\ldots \ldots$ \\
8.6 & $\ldots$ & $28^{\mathrm{e}}$ & $\ldots \ldots$ & $310^{\mathrm{f}}$ & $\ldots \ldots$ \\
$\ldots$ & $\ldots$ & $39 \mathrm{~g}$ & $\ldots \ldots$ & $480^{\mathrm{h}}$ & $\ldots \ldots$ \\
\hline
\end{tabular}

Trial 9, south chamber; Oct. 30-Nov. 11, 1939; cow no. 1003, weight $517 \mathrm{~kg} ; \mathrm{W}^{3 / 4}=108 \mathrm{~kg}^{3 / 4}$

\begin{tabular}{|c|c|c|c|c|c|c|}
\hline Feed: dry Sudan hay, $5,680 \mathrm{gm} \ldots \ldots \ldots \ldots \ldots$ & 114.0 & & 2,461 & & 23,990 & \\
\hline Feces................................... & $\ldots$ & 44.0 & $\ldots \ldots$ & 787 & $\ldots \ldots$ & 8,040 \\
\hline Digested nitrogen, carbon, or energy . . . . . . & 70.0 & $\ldots$ & 1,674 & $\cdots \cdots$ & 15,950 & $\ldots \ldots$ \\
\hline Urine $\ldots \ldots \ldots \ldots \ldots \ldots \ldots \ldots \ldots \ldots \ldots$ & $\ldots$ & 60.0 & $\ldots \ldots$ & 175 & & $1,750^{\mathrm{a}}$ \\
\hline 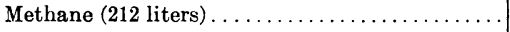 & $\ldots$ & $\ldots$ & & $114^{\mathrm{b}}$ & & $2,010^{\circ}$ \\
\hline Metabolizable nitrogen, carbon, or energy. . & 10.0 & $\ldots$ & 1,385 & & 12,190 & $\ldots \ldots$ \\
\hline Milk............................... & $\ldots$ & $\ldots$ & $\ldots \ldots$ & & $\ldots \ldots$ & $\ldots \ldots$ \\
\hline Katabolizable nitrogen, carbon, or energy.... & 10.0 & . & 1,385 & & 12,190 & \\
\hline Heat (respiration, 2,628 liters $\left.\mathrm{CO}_{2}\right) \ldots \ldots \ldots \ldots$ & $\ldots$ & & & $1,409^{d}$ & & $12,530^{\mathrm{k}}$ \\
\hline Gain in body substance.................. & 10.0 & $\ldots$ & & -24 & $\ldots \ldots$ & $-340^{\mathrm{i}}$ \\
\hline Gain in body protein $(\mathrm{N}$ gain $\times 6.25) \ldots \ldots \ldots$ & 10.0 & $\ldots$ & $32^{\mathrm{e}}$ & $\ldots \ldots$ & $360^{f}$ & $\ldots \ldots$ \\
\hline Gain in body fat $(\mathrm{C}$ in gained fat $\times 1.31) \ldots \ldots$ & $\ldots$ & ... & & $-56 \mathrm{~g}$ & & $700^{\mathrm{h}}$ \\
\hline
\end{tabular}


TABLE A (Continued)

\begin{tabular}{|c|c|c|c|c|c|c|}
\hline & \multicolumn{2}{|c|}{ Nitrogen } & \multicolumn{2}{|c|}{ Carbon } & \multicolumn{2}{|c|}{ Energy } \\
\hline . & $\underset{(\mathrm{gm})}{\operatorname{In}}$ & $\underset{\text { (gm) }}{\text { Out }}$ & $\underset{(\mathrm{gm})}{\operatorname{In}}$ & $\begin{array}{c}\text { Out } \\
(\mathrm{gm})\end{array}$ & $\underset{(\mathrm{kcal})}{\mathrm{In}}$ & $\underset{\text { (kcal) }}{\text { Out }}$ \\
\hline
\end{tabular}

Trial 12, north chamber; Dec. 4-22, 1939; cow no. 1007, weight $463 \mathrm{~kg}$; W3/4 $=100 \mathrm{~kg}^{3 / 4}$

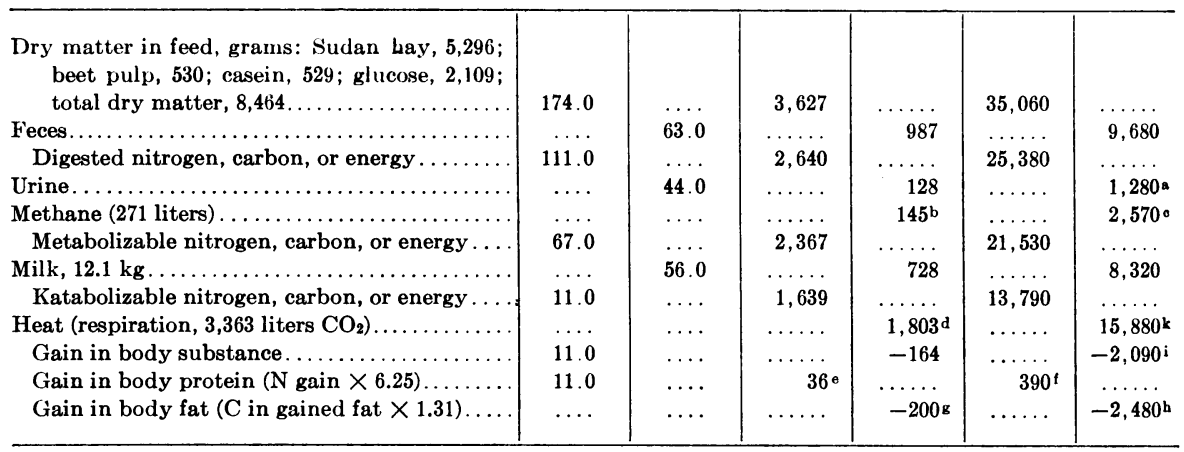

Trial 14, north chamber; Jan. 29-Feb. 10, 1940; cow no. 1007, weight $463 \mathrm{~kg}$; W3/4 $=100 \mathrm{~kg}^{3 / 4}$

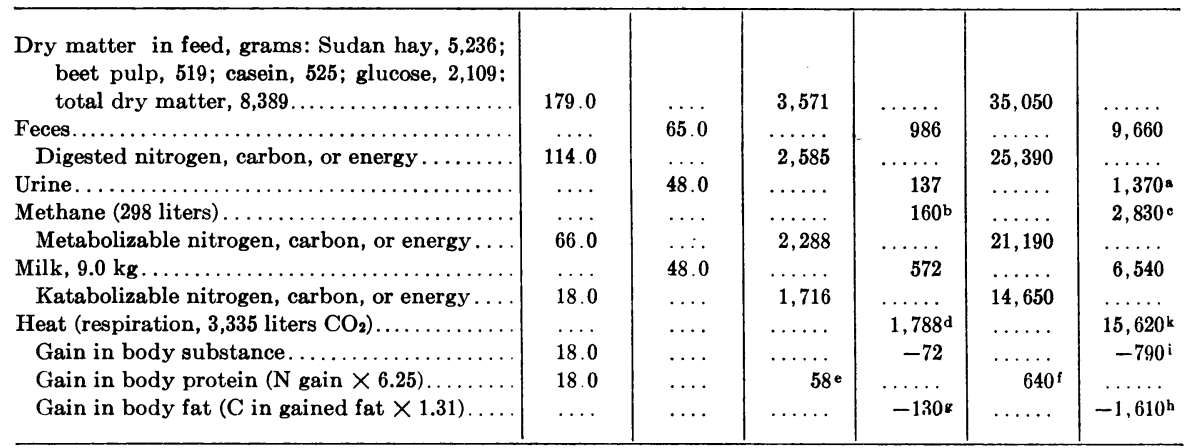

Trial 16, north chamber; Feb. 19-March 2, 1940; cow no. 1007, weight $460 \mathrm{~kg}$; W3/4 $=99 \mathrm{~kg}^{3 / 4}$

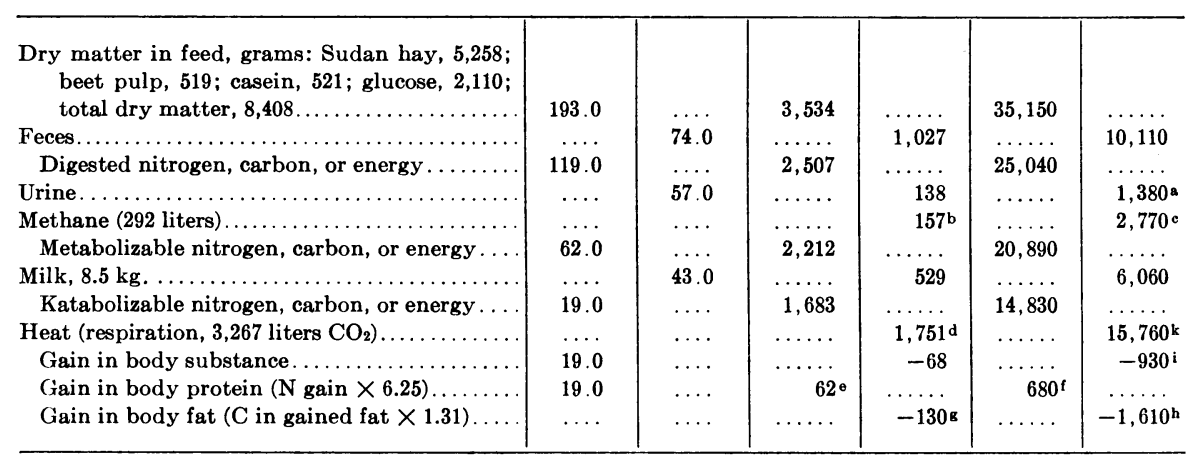


TABLE A (Continued)

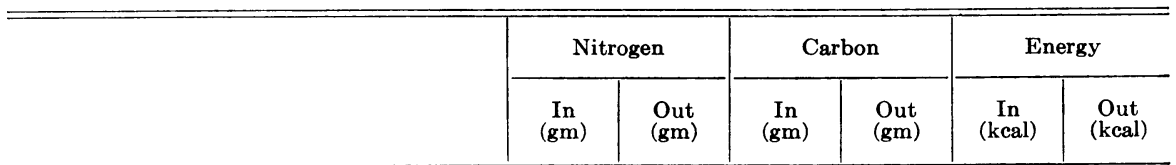

Trial 12, south chamber; Dec. 4-22, 1939; cow no 1021, weight $474 \mathrm{~kg}$; W3/4 $=102 \mathrm{~kg}^{3 / 4}$

Dry matter in feed, grams: Sudan hay, 4,883 ; heet pulp, 530; casein, 529; glucose, 2,109; total dry matter, 8,051 .

Feces.....

Digested nitrogen, carbon, or energy . .........

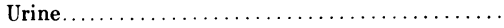

Methane (203 liters).

Metabolizable nitrogen, carbon, or energy . .

Milk, $12.5 \mathrm{~kg}$.

Katabolizable nitrogen, carbon, or energy .

Heat (respiration, 3,288 liters $\mathrm{CO}_{2}$ ).

Gain in body substance.

Gain in body protein ( $\mathrm{N}$ gain $\times 6.25)$

Gain in body fat $(\mathrm{C}$ in gained fat $\times 1.31)$.

\begin{tabular}{|c|c|c|c|c|c} 
& & & & & \\
166.0 & $\ldots$ & 3,448 & $\ldots \ldots$ & 33,320 & $\ldots \ldots$ \\
$\ldots$ & 60.0 & $\ldots \ldots$ & 944 & $\ldots \ldots$ & 9,320 \\
106.0 & $\ldots$ & 2,504 & $\ldots \ldots$ & 24,000 & $\ldots \ldots$ \\
$\ldots$ & 34.0 & $\ldots \ldots$ & 116 & $\ldots \ldots$ & $1,160^{\mathrm{a}}$ \\
$\ldots$ & $\ldots$ & $\ldots \ldots$ & $109^{\mathrm{b}}$ & $\ldots \ldots$ & $1,930^{\circ}$ \\
72.0 & $\ldots$ & 2,279 & $\ldots \ldots$ & 20,910 & $\ldots \ldots$ \\
$\ldots$ & 52.0 & $\ldots \ldots$ & 795 & $\ldots \ldots$ & 9,150 \\
20.0 & $\ldots$ & 1,484 & $\ldots \ldots$ & 11,780 & $\ldots \ldots$ \\
$\ldots$ & $\ldots$ & $\ldots \ldots$ & $1,762^{\mathrm{d}}$ & $\ldots \ldots$ & $15,310^{\mathrm{k}}$ \\
20.0 & $\ldots$ & $\ldots \ldots$ & -278 & $\ldots \ldots$ & $-3,550^{\mathrm{i}}$ \\
20.0 & $\ldots$ & $65^{\mathrm{e}}$ & $\ldots \ldots$ & $710^{\mathrm{f}}$ & $\ldots \ldots$ \\
$\ldots$ & $\ldots$ & $\ldots \ldots$ & $-343 \mathrm{~g}$ & $\ldots \ldots$ & $-4,260^{\mathrm{b}}$ \\
\hline
\end{tabular}

Trial 14, south chamber; Jan. 29-Feb. 10, 1940; cow no. 1021, weight $478 \mathrm{~kg}$; W W $^{1 / 4}=102 \mathrm{~kg}^{3 / 4}$

Dry matter in feed, grams: Sudan hay, 5,126 ; beet pulp, 475 ; barley, 3,281 ; total dry matter, 8,882 .

Feces...

Urine.

Methane (329 liters)

Metabolizable nitrogen, carbon, or energy . .

Milk, $10.5 \mathrm{~kg} \ldots \ldots \ldots \ldots \ldots \ldots \ldots \ldots \ldots \ldots \ldots$

Katabolizable nitrogen, carbon, or energy ..

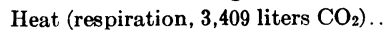

Gain in body substance..................

Gain in body protein $(\mathrm{N}$ gain $\times 6.25) \ldots \ldots \ldots$

Gain in body fat $(\mathrm{C}$ in gained fat $\times 1.31)$.....

\begin{tabular}{|c|c|c|c|c|c} 
& & & & & \\
164.0 & $\ldots$ & 3,791 & $\ldots \ldots$ & 37,920 & $\ldots \ldots$ \\
$\ldots$. & 63.0 & $\ldots \ldots$ & 1,140 & $\ldots \ldots$ & 11,280 \\
101.0 & $\ldots$ & 2,651 & $\ldots \ldots$ & 26,640 & $\ldots \ldots$ \\
$\ldots$ & 46.0 & $\ldots \ldots$ & 129 & $\ldots \ldots$ & $1,290^{\mathrm{a}}$ \\
$\ldots$ & $\ldots$ & $\ldots \ldots$ & $176^{\mathrm{b}}$ & $\ldots \ldots$ & $3,130^{\circ}$ \\
55.0 & $\ldots$ & 2,346 & $\ldots \ldots$ & 22,220 & $\ldots \ldots$ \\
$\ldots$ & 48.0 & $\ldots \ldots$. & 682 & $\ldots \ldots$ & 7,900 \\
7.0 & $\ldots$ & 1,664 & $\ldots \ldots$ & 14,320 & $\ldots \ldots$ \\
$\ldots$ & $\ldots$ & $\ldots \ldots$ & $1,827^{\mathrm{d}}$ & $\ldots \ldots$ & $16,380^{\mathrm{k}}$ \\
7.0 & $\ldots$ & $\ldots \ldots$ & -163 & $\ldots \ldots$ & $-2,060^{\mathrm{i}}$ \\
7.0 & $\ldots$ & $23 \mathrm{e}$ & $\ldots \ldots$ & $250^{\mathrm{f}}$ & $\ldots \ldots \ldots$ \\
$\ldots$ & $\ldots$ & $\ldots \ldots$ & $-186 \mathrm{~g}$ & $\ldots \ldots$ & $-2,310^{\mathrm{b}}$ \\
\hline
\end{tabular}

Trial 16, south chamber; Feb. 19-March 2, 1940; cow no. 1021, wøight $473 \mathrm{~kg}$; W3/4 $=101 \mathrm{~kg}^{3 / 4}$

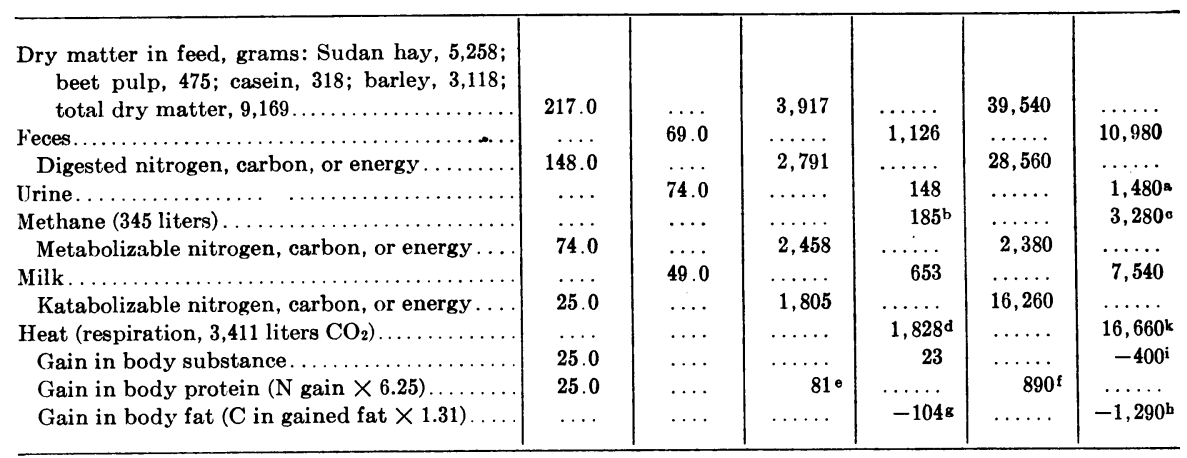


TABLE A (Continued)

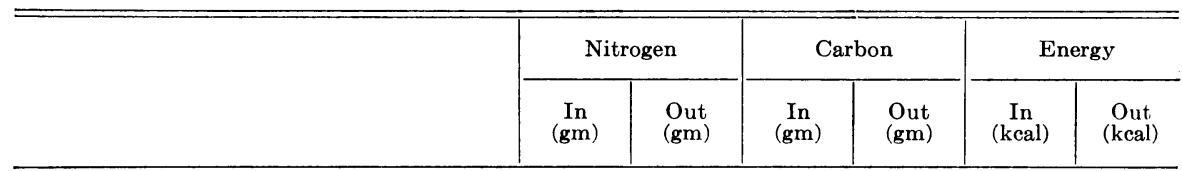

Trial 18, north chamber; March 25-April 6, 1940; cow no. 1007, weight $470 \mathrm{~kg}$; W3/4 $=101 \mathrm{~kg}^{3 / 4}$

\begin{tabular}{|c|c|c|c|c|c|c|}
\hline $\begin{array}{r}\text { Dry matter in feed, grams: Sudan hay. } 5,219 ; \\
\text { beet pulp, } 386 ; \text { casein, } 241 ; \text { barley, } 2,396 ; \\
\text { total dry matter, } 8,242 \ldots \ldots \ldots \ldots \ldots \ldots \ldots\end{array}$ & 175.0 & $\ldots$ & 3,572 & $\ldots \ldots$ & 34,730 & $\ldots \ldots$ \\
\hline Feces............... & $\ldots$ & 64.0 & $\ldots \ldots$ & $1,082 \dagger$ & $\ldots \ldots$ & 10,530 \\
\hline Digested nitrogen, carbon, or energy . . . . . . . & 111.0 & $\ldots$ & 2,490 & $\ldots \ldots$ & 24,200 & $\ldots \ldots$ \\
\hline Urine $\ldots \ldots \ldots \ldots \ldots \ldots \ldots \ldots \ldots \ldots \ldots$ & $\ldots$ & 68.0 & & 136 & $\ldots \ldots$ & $1,360^{\mathrm{a}}$ \\
\hline Milk, 8.6 kg. . . . . . . $\ldots \ldots \ldots \ldots \ldots \ldots$ & $\ldots$ & 44.0 & $\ldots \ldots$ & 548 & $\ldots \ldots$ & 6,360 \\
\hline Katabolizable nitrogen, carbon, or energy . & $\cdots$ & -1.0 & 1,645 & $\ldots \ldots$ & 13,620 & $\ldots \ldots$ \\
\hline Heat (respiration, 3,151 liters $\left.\mathrm{CO}_{2}\right) \ldots \ldots \ldots$ & $\ldots$ & $\ldots$ & $\ldots \ldots$ & $1,689 \mathrm{~d}$ & $\ldots$ & $14,170^{\mathrm{k}}$ \\
\hline Gain in body substance . . . . . . . . . & $\ldots$ & -1.0 & & -44 & & $-550^{\mathrm{i}}$ \\
\hline Gain in body protein $(\mathrm{N}$ gain $\times 6.25) \ldots \ldots$ & & -1.0 & & $-3 e$ & $\ldots$ & $-40^{t}$ \\
\hline
\end{tabular}

Trial 20, north chamber; April 22-May 5, 1940; cow no. 1007, weight $464 \mathrm{~kg}$; W3/4 $=100 \mathrm{~kg}^{3 / 4}$

\begin{tabular}{|c|c|c|c|c|c|c|}
\hline $\begin{array}{r}\text { Dry matter in feed, grams: Sudan hay, } 5,274 ; \\
\text { beet pulp, } 395 ; \text { casein, } 402 ; \text { glucose, } 1,646 ; \\
\text { total dry matter, } 7,717 \ldots \ldots \ldots \ldots \ldots \ldots \ldots\end{array}$ & 163.0 & $\ldots$ & 3,291 & $\ldots \ldots$ & 31,990 & $\ldots \ldots$ \\
\hline Urine $\ldots \ldots \ldots \ldots \ldots \ldots \ldots \ldots \ldots \ldots$ & $\ldots$ & 44.0 & $\cdots \cdots$ & 125 & & $1,250^{\mathrm{a}}$ \\
\hline 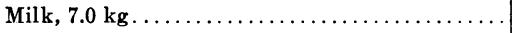 & $\ldots$ & 35.0 & $\ldots \ldots$ & 440 & $\ldots$. & 5,150 \\
\hline Katabolizable nitrogen, carbon, or energy. & 25.0 & $\ldots$ & 1,657 & $\ldots \ldots$ & 13,620 & $\ldots \ldots$ \\
\hline Heat (respiration, 3,031 liters $\mathrm{CO}_{2}$ ) $\ldots \ldots \ldots$ & $\ldots$ & & $\ldots \ldots$ & $1,625^{\mathrm{d}}$ & $\ldots \ldots$ & $13,340^{k}$ \\
\hline Gain in body substance............. & 25.0 & & 32 & $\ldots \ldots$ & $280^{i}$ & $\ldots \ldots$ \\
\hline Gain in body protein $(\mathrm{N}$ gain $\times 6.25) \ldots \ldots$ & 25.0 & $\ldots$ & $81^{\text {e }}$ & $\ldots \ldots$ & $890^{f}$ & $\ldots \ldots$ \\
\hline
\end{tabular}

Trial 22, north chamber; May 13-25, 1940; cow no. 1007, weight $457 \mathrm{~kg}$; W3/4 $=99 \mathrm{~kg}^{3 / 4}$

\begin{tabular}{|c|c|c|c|c|c|c|}
\hline Feed: dry Sudan hay, $5,318 \mathrm{gm} \ldots \ldots \ldots \ldots \ldots$ & 104.0 & $\ldots$ & 2,328 & $\ldots \ldots$ & 22,470 & $\ldots \ldots$ \\
\hline Feces $\ldots \ldots \ldots \ldots \ldots \ldots \ldots \ldots \ldots \ldots \ldots$ & $\ldots$ & 40.0 & $\ldots \ldots$ & 728 & & 7,260 \\
\hline Digested nitrogen, carbon, or energy . . . . . . . & 64.0 & $\ldots$ & 1,600 & $\ldots \ldots$ & 15,210 & $\ldots \ldots$ \\
\hline Urine $\ldots \ldots \ldots \ldots \ldots \ldots \ldots \ldots \ldots$ & $\ldots$ & 51.0 & & 132 & & $1,320^{\mathrm{a}}$ \\
\hline Methane $(194$ liters $) \ldots \ldots \ldots \ldots \ldots \ldots \ldots \ldots$ & $\ldots$ & $\ldots$ & & $104^{b}$ & $\ldots \ldots$ & $1,840^{\circ}$ \\
\hline Metabolizable nitrogen, carbon, or energy . . . . & 13.0 & ... & 1,364 & $\ldots \ldots$ & 12,050 & $\ldots \ldots$ \\
\hline Heat (respiration, 2,405 liters $\mathrm{CO}_{2}$ ) $\ldots \ldots \ldots \ldots$ & $\ldots$ & & $\ldots \ldots$ & $1,289^{d}$ & $\ldots \ldots$ & $11,180^{k}$ \\
\hline Gain in body substance. . . . . . . . . . & 13.0 & & 75 & & $870^{\mathrm{i}}$ & \\
\hline Gain in body protein $(\mathrm{N}$ gain $\times 6.25) \ldots$ & 13.0 & & $42^{\mathrm{e}}$ & & $460^{f}$ & $\ldots \ldots$ \\
\hline Gain in body fat $(\mathrm{C}$ in gained fat $\times 1.31) \ldots$ & $\ldots$ & $\ldots$ & $33 \mathrm{~g}$ & & $410^{\mathrm{h}}$ & $\ldots \ldots$ \\
\hline
\end{tabular}

† Carbon determination in feces lost, this figure calculated based on equal digestibility of carbon and energy . 
TABLE A (Continued)

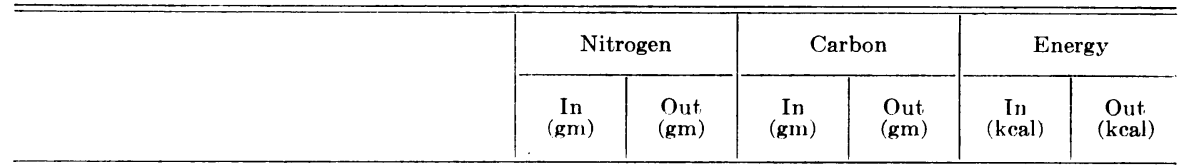

'Trial 18, south chamber; March 25-April 6, 1940; cow no. 1021, weight $473 \mathrm{~kg}$; W3/4 $=101 \mathrm{~kg}^{3 / 4}$

Dry matter in feed, grams: Sudan hay, 5,219 ; beet pulp, 386; casein, 402; glucose, 1,646; total dry matter, 7,653 Feces. .

Digested nitrogen, carbon, or energy.

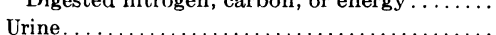

Methane (256 liters).

Metabolizable nitrogen, carbon, or ene

Milk, $8.0 \mathrm{~kg} .$.

Katabolizable nitrogen, carbon, or energy . . . .

Heat (respiration, 2,989 liters $\mathrm{CO}_{2}$ ) ..........

Gain in body substance................

Gain in body protein ( $\mathrm{N}$ gain $\times 6.25) \ldots \ldots \ldots$

Gain in body fat ( $\mathrm{C}$ in gained fat $\times 1.31)$.

\begin{tabular}{|c|c|c|c|c|c} 
& & & & & \\
159.0 & $\ldots$ & 3,275 & $\ldots \ldots$ & 31,350 & $\ldots \ldots$ \\
$\ldots$ & 60.0 & $\ldots \ldots$ & $916 \ddagger$ & $\ldots \ldots$ & 9.030 \\
99.0 & $\ldots$. & 2,359 & $\ldots \ldots$ & 22,320 & $\ldots \ldots$ \\
$\ldots$ & 64.0 & $\ldots \ldots$ & 125 & $\ldots \ldots$ & $1,250^{\mathrm{a}}$ \\
$\ldots$ & $\ldots$ & $\ldots \ldots$ & $137 \mathrm{~b}$ & $\ldots \ldots$ & $2,430^{\mathrm{c}}$ \\
35.0 & $\ldots$ & 2,097 & $\ldots \ldots$ & 18,640 & $\ldots \ldots$ \\
$\ldots$ & 38.0 & $\ldots \ldots$ & 510 & $\ldots \ldots$ & 5,970 \\
$\ldots$ & -3.0 & 1,587 & $\ldots \ldots$ & 12,670 & $\ldots \ldots$ \\
$\ldots$ & $\ldots$ & $\ldots \ldots$ & $1,602^{\mathrm{d}}$ & $\ldots \ldots$ & $12,840^{\mathrm{k}}$ \\
$\ldots$ & -3.0 & $\ldots \ldots$ & -15 & $\ldots \ldots$ & $-170^{\mathrm{i}}$ \\
$\ldots$ & -3.0 & $\ldots \ldots$ & $-10^{\mathrm{e}}$ & $\ldots \ldots$ & $-110^{\mathrm{f}}$ \\
$\ldots$ & $\ldots \ldots$ & $\ldots \ldots$ & $-5^{\mathrm{g}}$ & $\ldots \ldots$ & $-60^{\mathrm{b}}$ \\
\hline
\end{tabular}

Trial 20, south chamber; April 22-May 5, 1940; cow no. 1021, weight $473 \mathrm{~kg}$; W3/4 $=101 \mathrm{~kg}^{3 / 4}$

Dry matter in feed, grams: Sudan hay, 5,274; beet pulp, 395; casein, 402; glucose, 1,646; total dry matter, $7,717 \ldots \ldots \ldots \ldots \ldots \ldots \ldots$ Feces.....

Digested nitrogen, carbon, or energy.

Urine.

Methane (252 liters)

Metabolizable nitrogen, carbon, or energy

Milk, $7.2 \mathrm{~kg} \ldots \ldots \ldots \ldots \ldots \ldots \ldots \ldots \ldots \ldots \ldots$

Katabolizable nitrogen, carbon, or energy . .

Heat (respiration, 2,952 liters $\mathrm{CO}_{2}$ ).

Gain in body substance

Gain in body protein ( $N$ gain $\times 6.25)$

Gain in body fat ( $\mathrm{C}$ in gained fat $\times 1.31) \ldots$

\begin{tabular}{|c|c|c|c|c|c} 
& & & & & \\
163.0 & $\ldots$ & 3,291 & $\ldots \ldots$ & 31,990 & $\ldots \ldots$ \\
$\ldots$ & 60.0 & $\ldots \ldots$ & 954 & $\ldots \ldots$ & 9,400 \\
103.0 & $\ldots$ & 2,337 & $\ldots \ldots$ & 22,590 & $\ldots \ldots$ \\
$\ldots$ & 49.0 & $\ldots \ldots$ & 132 & $\ldots \ldots$ & $1,320^{\mathrm{a}}$ \\
$\ldots$ & $\ldots$ & $\ldots \ldots$ & $135^{\mathrm{b}}$ & $\ldots \ldots$ & $2,390^{\mathrm{c}}$ \\
54.0 & $\ldots$ & 2,070 & $\ldots \ldots$ & 18,880 & $\ldots \ldots$ \\
$\ldots$ & 36.0 & $\ldots \ldots$ & 462 & $\ldots \ldots$ & 5,370 \\
18.0 & $\ldots \ldots$ & 1,608 & $\ldots \ldots$ & 13,510 & $\ldots \ldots$ \\
$\ldots$. & $\ldots$ & $\ldots \ldots$ & $1,582^{\mathrm{d}}$ & $\ldots \ldots$ & $13,270^{\mathrm{k}}$ \\
18.0 & $\ldots$ & 26 & $\ldots \ldots$ & $240^{\mathrm{i}}$ & $\ldots \ldots$ \\
18.0 & $\ldots$ & $58^{\mathrm{e}}$ & $\ldots \ldots$ & $640^{\mathrm{f}}$ & $\ldots \ldots$ \\
$\ldots$ & $\ldots \ldots$ & $\ldots \ldots$ & $-32^{\mathrm{g}}$ & $\ldots \ldots$ & $-400^{\mathrm{b}}$ \\
\hline
\end{tabular}

Trial 22, south chamber; May 13-25, 1940; cow no. 1021 , weight $466 \mathrm{~kg} ; \mathrm{W}^{3 / 4}=100 \mathrm{~kg}^{3 / 4}$

\begin{tabular}{|c|c|c|c|c|c|c|}
\hline Feed: dry Sudan hay, $5,318 \mathrm{gm} \ldots \ldots \ldots \ldots \ldots$ & 104.0 & $\ldots$ & 2,328 & $\ldots \ldots$ & 22,470 & $\cdots$ \\
\hline Feces. $\ldots \ldots \ldots \ldots \ldots \ldots \ldots \ldots \ldots$ & $\ldots$ & 42.0 & $\ldots \ldots$ & 758 & $\ldots \ldots$ & 7,440 \\
\hline Digested nitrogen, carbon, or energy . . . . . . . & 62.0 & $\ldots$ & 1,570 & $\ldots \ldots$ & 15,030 & $\ldots \ldots$ \\
\hline Methane (197 liters) $\ldots \ldots \ldots \ldots \ldots \ldots \ldots$ & $\ldots$ & $\ldots$ & & $106^{\mathrm{b}}$ & & $1,870^{\circ}$ \\
\hline Metabolizable nitrogen, carbon, or energy.... & 9.0 & $\ldots$ & 1,343 & & 11,950 & \\
\hline Heat (respiration, 2,359 liters $\mathrm{CO}_{2}$ ) $\ldots \ldots \ldots$ & $\ldots$ & . & $\ldots \ldots$ & $1,264^{\mathrm{d}}$ & $\ldots \ldots$ & $11,010^{\mathrm{k}}$ \\
\hline Gain in body substance............... & 9.0 & & 79 & & $940^{\mathrm{i}}$ & \\
\hline Gain in body protein $(\mathrm{N}$ gain $\times 6.25)$.. & 9.0 & & $29^{\mathrm{e}}$ & & $320^{f}$ & \\
\hline Gain in body fat ( $\mathrm{C}$ in gained fat $\times 1.31)$. & $\ldots$ & & $50 \mathrm{~g}$ & & $620^{\mathrm{h}}$ & $\ldots \ldots$ \\
\hline
\end{tabular}

$\ddagger$ Carbon determination in feces lost, this figure calculated based on 9.86 kcal per gram of carbon in feces of same cow from trials 12 and 20 . 
TABLE A (Continued)

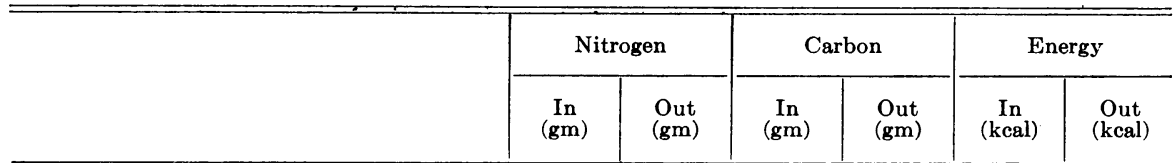

Trial 24, south chamber; Jan 27-Feb. 14, 1941; cow no. 728, weight $372 \mathrm{~kg}$; W3/4 $=85 \mathrm{~kg}^{3 / 4}$

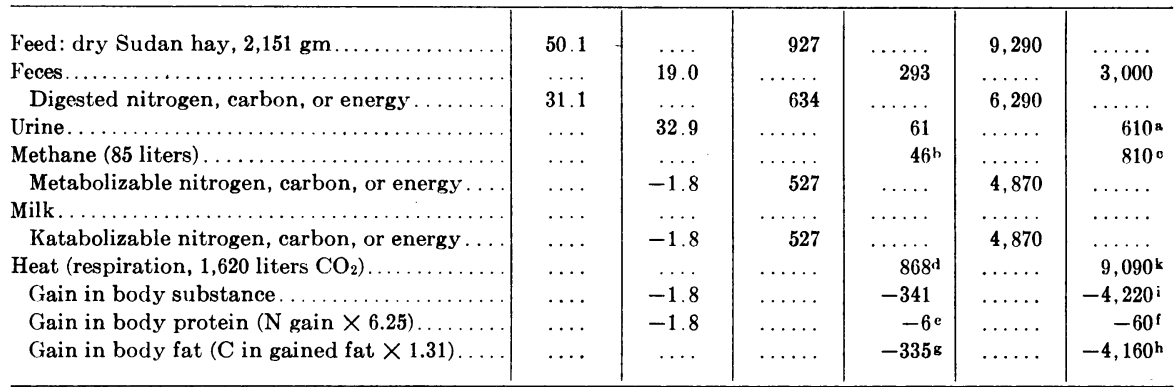

Trial 25, south chamber; Feb. 24-March 14, 1941 ; cow no. 728 , weight $371 \mathrm{~kg} ; \mathrm{W}^{3 / 4}=85 \mathrm{~kg}^{3 / 4}$

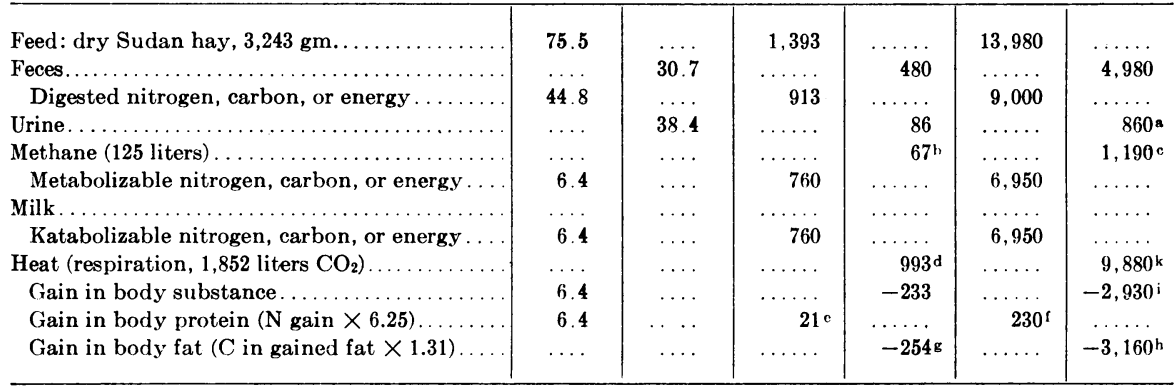

Trial 26, south chamber; March 24-April 15, 1941; cow no. 728, weight $380 \mathrm{~kg}$.; $\mathrm{W}^{3 / 4}=86 \mathrm{~kg}^{3 / 4}$

\begin{tabular}{|c|c|c|c|c|c|c|}
\hline $\begin{array}{l}\text { Dry matter in feed, grams: Sudan hay, } 2,186 \text {; } \\
\text { casein, } 144 ; \text { glucose }, 1,107 ; \text { total dry matter, } \\
\quad 3,437 \ldots \ldots \ldots \ldots \ldots \ldots \ldots \ldots \ldots \ldots \ldots \ldots \ldots \ldots\end{array}$ & 72.3 & $\ldots$ & 1,455 & & 14,340 & \\
\hline 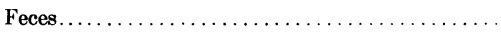 & 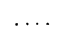 & 31.0 & & 369 & $\ldots \ldots$ & 3,840 \\
\hline Digested nitrogen, carbon, or energy . . & 41.3 & $\ldots$ & 1,086 & & 10,500 & $\ldots \ldots$ \\
\hline Urine $\ldots \ldots \ldots \ldots \ldots \ldots \ldots \ldots \ldots \ldots$ & $\ldots$ & 24.6 & $\ldots \ldots$ & 60 & $\ldots \ldots$ & $600^{\mathrm{a}}$ \\
\hline Methane $(132$ liters $) \ldots \ldots \ldots \ldots \ldots \ldots \ldots \ldots$ & $\ldots$ & $\ldots$ & $\ldots \ldots$ & $71^{b}$ & $\ldots \ldots$ & $1,250^{\mathrm{c}}$ \\
\hline Metabolizable nitrogen, carbon, or energy . . . & 16.7 & $\ldots$ & 955 & & 8,650 & $\ldots \ldots$ \\
\hline 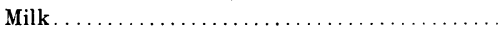 & & $\ldots$ & . & & $\ldots \ldots$ & $\ldots \ldots$ \\
\hline Katabolizable nitrogen, carbon, or energy . . & 16.7 & $\ldots$ & 955 & & 8,650 & $\ldots \ldots$ \\
\hline Heat (respiration, 2,137 liters $\mathrm{CO}_{2}$ ) $\ldots \ldots \ldots \ldots \ldots$ & $\ldots$ & $\ldots$ & $\ldots \ldots$ & $1,145^{d}$ & $\ldots \ldots$ & $11,090^{\mathrm{k}}$ \\
\hline Gain in body substance ................... & 16.7 & $\ldots$ & $\ldots \ldots$ & -190 & $\ldots \ldots$ & $-2,440^{i}$ \\
\hline Gain in body protein $(\mathrm{N}$ gain $\times 6.25) \ldots \ldots \ldots$ & 16.7 & $\ldots$ & $54^{\circ}$ & & $590^{\mathrm{f}}$ & \\
\hline Gain in body fat $(\mathrm{C}$ in gained fat $\times 1.31) \ldots$ & $\ldots$ & $\ldots$ & & $-244 \mathrm{~g}$ & $\ldots \ldots$ & $-3,030^{\mathrm{h}}$ \\
\hline
\end{tabular}


TABLE A (Continued)

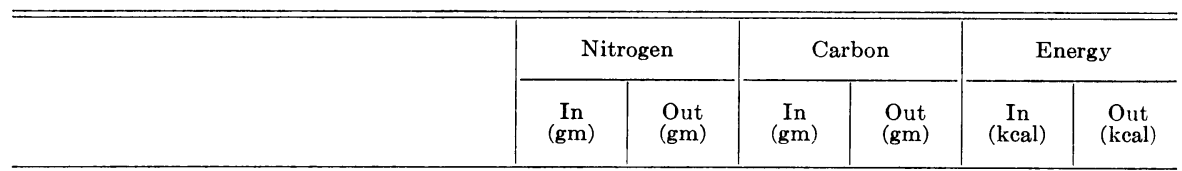

Trial 27, north chamber; April 6-18, 1941; cow no. 732, weight $430 \mathrm{~kg}$; W3/4 $=94 \mathrm{~kg}^{3 / 4}$

Dry matter in feed, grams: Sudan hay, 2,186; casein, 144 ; glucose, 1,107 ; total dry matter, 3,437 . . . . Feces

Digested nitrogen, carbon, or energy ........

Urine . . . . . . . . . . . . . . . . . . . . . . . . . .

Methane (226 liters)

Metabolizable nitrogen, carbon, or energy .... Milk.

Katabolizable nitrogen, carbon, or energy . .

Heat (respiration, 2,259 liters $\mathrm{CO}_{2}$ ).

Gain in body substance. .

Gain in body protein ( $\mathrm{N}$ gain $\times 6.25)$

Gain in body fat $(\mathrm{C}$ in gained fat $\times 1.31) \ldots$

\begin{tabular}{c|c|c|c|c|c} 
& & & & & \\
72.3 & $\ldots$ & 1,455 & $\ldots \ldots$ & 14,340 & $\ldots \ldots$ \\
$\ldots$ & 28.2 & $\ldots \ldots$ & 348 & $\ldots \ldots$ & 3,618 \\
44.1 & $\ldots$ & 1,107 & $\ldots \ldots$ & 10,720 & $\ldots \ldots$ \\
$\ldots$ & 31.0 & $\ldots \ldots$ & 77 & $\ldots \ldots$ & $770^{\mathrm{a}}$ \\
$\ldots$ & $\ldots$ & $\ldots \ldots$ & $121^{\mathrm{b}}$ & $\ldots \ldots$ & $2,150^{\mathrm{c}}$ \\
13.1 & $\ldots$ & 909 & $\ldots \ldots$ & 7,800 & $\ldots \ldots$ \\
$\ldots$ & $\ldots$ & $\ldots \ldots$ & $\ldots \ldots$ & $\ldots \ldots$ & $\ldots \ldots$ \\
13.1 & $\ldots$ & 909 & $\ldots \ldots$ & 7,800 & $\ldots \ldots$ \\
$\ldots$ & $\ldots$ & $\ldots \ldots$ & $1,211^{\mathrm{d}}$ & $\ldots \ldots$ & $11,610^{\mathrm{k}}$ \\
13.1 & $\ldots$ & $\ldots \ldots$ & -302 & $\ldots \ldots$ & $-3,810^{\mathrm{i}}$ \\
13.1 & $\ldots$ & 43 & $\ldots \ldots$ & $470^{\mathrm{f}}$ & $\ldots \ldots$ \\
$\ldots$ & $\ldots$ & $\ldots \ldots$ & $-345^{\mathrm{g}}$ & $\ldots \ldots$ & $-4,280^{\mathrm{b}}$ \\
\hline
\end{tabular}

Trial 28, south chamber; June 16-July 2, 1941; cow no. 728, weight $347 \mathrm{~kg}$; W3/4 $=80 \mathrm{~kg}^{3 / 4}$

Dry matter in feed, grams: Sudan hay, 3,580 ; beet pulp, 400 ; casein, 90 ; barley, 4,183 ; total dry matter, 8,253 .

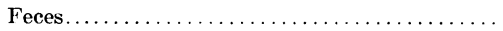

Digested nitrogen, carbon, or energy

Urine....

Methane (262 liters)

Metabolizable nitrogen, carbon, or energy . .

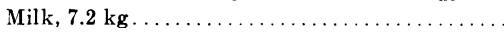

Katabolizable nitrogen, carbon, or energy .

Heat (respiration, 2,935 liters $\mathrm{CO}_{2}$ )

Gain in body substance. .

Gain in body protein $(\mathrm{N}$ gain $\times 6.25)$.

Gain in body fat $(\mathrm{C}$ in gained fat $\times 1.31)$

\begin{tabular}{|c|c|c|c|c|c} 
& & & & & \\
176.8 & $\ldots$ & 3,641 & $\ldots \ldots$ & 35,870 & $\ldots \ldots$ \\
$\ldots$. & 69.0 & $\ldots \ldots$ & 978 & $\ldots \ldots$ & 10,020 \\
107.8 & $\ldots$ & 2,663 & $\ldots \ldots$ & 25,850 & $\ldots \ldots$ \\
$\ldots$ & 28.7 & $\ldots \ldots$ & 77 & $\ldots \ldots$ & $770^{\mathrm{a}}$ \\
$\ldots$ & $\ldots$ & $\ldots \ldots$ & $140^{\mathrm{b}}$ & $\ldots \ldots$ & $2,490^{\mathrm{c}}$ \\
79.1 & $\ldots$ & 2,446 & $\ldots \ldots$ & 22,590 & $\ldots \ldots$ \\
$\ldots$ & 42.5 & $\ldots \ldots$ & 571 & $\ldots \ldots$ & 6,410 \\
36.6 & $\ldots$ & 1,875 & $\ldots \ldots$ & 16,180 & $\ldots \ldots$ \\
$\ldots$ & $\ldots$ & $\ldots \ldots$ & $1,573^{\mathrm{d}}$ & $\ldots \ldots$ & $12,610^{\mathrm{k}}$ \\
36.6 & $\ldots$ & 302 & $\ldots \ldots$ & $3,570^{\mathrm{i}}$ & $\ldots \ldots$ \\
36.6 & $\ldots$ & $119^{\mathrm{e}}$ & $\ldots \ldots$ & $1,300^{\mathrm{f}}$ & $\ldots \ldots$ \\
$\ldots$ & $\ldots$ & $183 \mathrm{~g}$ & $\ldots \ldots$ & $2,270^{\mathrm{h}}$ & $\ldots \ldots$ \\
\hline
\end{tabular}

Trial 29, south chamber; July 14-Aug. 1, 1941; cow no. 728, weight $347 \mathrm{~kg} ; \mathrm{W}^{3 / 4}=80 \mathrm{~kg}^{3 / 4}$
Dry matter in feed, grams: Sudan hay, 3,580; beet pulp, 327; casein, 308 ; glucose, 2,981; total dry matter, $7,196 \ldots \ldots \ldots \ldots \ldots \ldots \ldots$

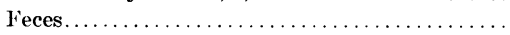

Digested nitrogen, carbon, or energy ........

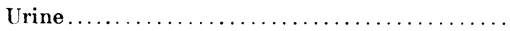

Methane (260 liters).

Metabolizable nitrogen, carbon, or energy ...

Milk, $5.8 \mathrm{~kg}$. .

Katabolizable nitrogen, carhnn, or energy ...

Heat (respiration, 2,930 liters $\mathrm{CO}_{2}$ ) ..........

Gain in body substance.

Gain in body protein $(\mathrm{N}$ gain $\times 6.25)$.

Gain in body fat ( $\mathrm{C}$ in gained fat $\times 1.31$ )

\begin{tabular}{|c|c|c|c|c|c} 
& & & & & \\
127.1 & $\ldots$ & 3,072 & $\ldots \ldots$ & 29,490 & $\ldots \ldots$ \\
$\ldots$ & 62.2 & $\ldots \ldots$ & 804 & $\ldots \ldots$ & 8,110 \\
64.9 & $\ldots$ & 2,268 & $\ldots \ldots$ & 21,380 & $\ldots \ldots$ \\
$\ldots$ & 27.0 & $\ldots \ldots$ & 99 & $\ldots \ldots$ & $990^{\mathrm{a}}$ \\
$\ldots$. & $\ldots$ & $\ldots \ldots$ & $139^{\mathrm{b}}$ & $\ldots \ldots$ & $2,470^{\mathrm{c}}$ \\
37.9 & $\ldots$ & 2,030 & $\ldots \ldots$ & 17,920 & $\ldots \ldots$ \\
$\ldots$ & 36.3 & $\ldots$. & 477 & $\ldots \ldots$ & 5,380 \\
1.6 & $\ldots$ & 1.553 & $\ldots \ldots$ & 12,540 & $\ldots \ldots$ \\
$\ldots$ & $\ldots$ & $\ldots \ldots$ & $1,570^{\mathrm{d}}$ & $\ldots \ldots$ & $12,750^{\mathrm{h}}$ \\
1.6 & $\ldots$ & $\ldots \ldots$ & -17 & $\ldots \ldots$ & $-210^{\mathrm{i}}$ \\
1.6 & $\ldots$ & 5 & $\ldots \ldots$ & $60^{\mathrm{f}}$ & $\ldots \ldots$ \\
$\ldots$ & $\ldots$ & $\ldots \ldots$ & $-22 \mathrm{~g}$ & $\ldots \ldots$ & $-270^{\mathrm{h}}$ \\
\hline
\end{tabular}


TABLE A (Concluded)

\begin{tabular}{l|c|c|c|c|c|c}
\hline \hline & \multicolumn{2}{|c|}{ Nitrogen } & \multicolumn{2}{|c|}{ Carbon } & \multicolumn{2}{|c}{ Energy } \\
\cline { 2 - 6 } & $\begin{array}{c}\text { In } \\
(\mathrm{gm})\end{array}$ & $\begin{array}{c}\text { Out } \\
(\mathrm{gm})\end{array}$ & $\underset{(\mathrm{gm})}{\text { In }}$ & $\begin{array}{c}\text { Out } \\
(\mathrm{gm})\end{array}$ & $\begin{array}{c}\text { In } \\
(\mathrm{kcal})\end{array}$ & $\begin{array}{c}\text { Out } \\
(\mathrm{kcal})\end{array}$ \\
\hline
\end{tabular}

Trial 27, south chamber; April 6-18, 1941, cow no. 728, weight $382 \mathrm{~kg}$; W W $^{3 / 4}=86 \mathrm{~kg}^{3 / 4}$

Dry matter in feed, grams: Sudan hay, 2,186; casein, 144 ; glucose, 1,107 ; total dry matter, 3,437 .

Feces.

Digested nitrogen, carbon, or energy

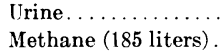

nitrogen, carbon, or energy ... Milk. . .

Katabolizable nitrogen, carbon, or energy .

Heat (respiration, 2,236 liters $\mathrm{CO}_{2}$ ).

Gain in body substance.

Gain in body protein ( $\mathrm{N}$ gain $\times 6.25)$

Gain in body fat ( $\mathrm{C}$ in gained fat $\times 1.31)$.

\begin{tabular}{|c|c|r|r|r|r} 
& & & & & \\
72.3 & $\ldots$ & 1,455 & $\ldots \ldots$ & 14,340 & $\ldots \ldots$ \\
$\ldots$ & 28.7 & $\ldots \ldots$ & 388 & $\ldots \ldots$ & 4,010 \\
43.6 & $\ldots$ & 1,067 & $\ldots$ & 10,330 & $\ldots \ldots$ \\
$\ldots$ & 26.3 & $\ldots \ldots$ & 65 & $\ldots \ldots$ & $650^{\mathrm{a}}$ \\
$\ldots$ & $\ldots$ & $\ldots$. & $99^{\mathrm{b}}$ & $\ldots \ldots$ & $1,760^{\mathrm{c}}$ \\
17.3 & $\ldots$ & 903 & $\ldots \ldots$ & 7,920 & $\ldots \ldots$ \\
$\ldots$ & $\ldots$ & $\ldots \ldots$ & $\ldots \ldots$ & $\ldots \ldots$ & $\ldots \ldots$ \\
17.3 & $\ldots$ & 903 & $\ldots \ldots$ & 7,920 & $\ldots \ldots$ \\
$\ldots$ & $\ldots$ & $\ldots \ldots$ & $1,198^{\mathrm{d}}$ & $\ldots \ldots$ & $11,660^{\mathrm{k}}$ \\
17.3 & $\ldots$ & $\ldots \ldots$ & -295 & $\ldots \ldots$ & $-3,740^{\mathrm{i}}$ \\
17.3 & $\ldots$ & $56^{\mathrm{e}}$ & $\ldots \ldots$ & $620^{\mathrm{f}}$ & $\ldots \ldots$ \\
$\ldots$ & $\ldots$ & $\ldots \ldots$ & $-351^{\mathrm{g}}$ & $\ldots \ldots$ & $-4,360^{\mathrm{h}}$ \\
\hline
\end{tabular}

Trial 28, north chamber; June 16-July 2, 1941; cow no. 732 , weight $378 \mathrm{~kg}$; W3/4 $=86 \mathrm{~kg}^{3 / 4}$

Dry matter in feed, grams: Sudan hay, 3,580 ; beet pulp, 400; casein, 376 ; glucose, 3,232 : total dry matter, 7,588 . .

Feces...

Digested nitrogen, carbon, or energy

Urine.

Methane (248 liters).

Metabolizable nitrogen, carbon, or energy.

Milk, $9.1 \mathrm{~kg} . .$.

Katabolizable nitrogen, carbon, or energy .

Heat (respiration, 2,978 liters $\mathrm{CO}_{2}$ ).

Gain in body substance. .

Gain in body protein ( $\mathrm{N}$ gain $\times 6.25)$

Gain in body fat $(\mathrm{C}$ in gained fat $\times 1.31)$

\begin{tabular}{|c|c|r|r|r|c} 
& & & & & \\
& & & & & \\
138.0 & $\ldots$ & 3,231 & $\ldots \ldots$ & 31,120 & $\ldots \ldots$ \\
$\ldots$ & 57.9 & $\ldots \ldots$ & 794 & $\ldots \ldots$ & 7,700 \\
80.1 & $\ldots$ & 2,437 & $\ldots \ldots$ & 23,420 & $\ldots \ldots$ \\
$\ldots$ & 27.4 & $\ldots \ldots$ & 104 & $\ldots \ldots$ & $1,040^{\mathrm{n}}$ \\
$\ldots$ & $\ldots$ & $\ldots \ldots$ & $133^{\mathrm{h}}$ & $\ldots \ldots$ & $2,360^{\mathrm{c}}$ \\
52.7 & $\ldots$ & 2,200 & $\ldots \ldots$ & 20,020 & $\ldots \ldots$ \\
$\ldots$ & 49.1 & $\ldots \ldots$ & 757 & $\ldots \ldots$ & 8,485 \\
3.6 & $\ldots$ & 1,443 & $\ldots \ldots$ & 11,540 & $\ldots \ldots$ \\
$\ldots$ & $\ldots$ & $\ldots \ldots$ & $1,596^{\mathrm{d}}$ & $\ldots \ldots$ & $13,460^{\mathrm{k}}$ \\
3.6 & $\ldots$ & $\ldots \ldots$ & -153 & $\ldots \ldots$ & $-1,920^{\mathrm{i}}$ \\
3.6 & $\ldots$ & $12^{\mathrm{e}}$ & $\ldots \ldots$ & $128^{\mathrm{f}}$ & $\ldots \ldots$ \\
$\ldots$ & $\ldots$ & $\ldots \ldots$ & $-165^{\mathrm{g}}$ & $\ldots \ldots$ & $-2,050^{\mathrm{h}}$ \\
& $\ldots$ & $\ldots$ & &
\end{tabular}

Trial 29, north chamber; July 14-Aug. 1, 1941; cow no. 732, weight $373 \mathrm{~kg}$; W3/4 $=85 \mathrm{~kg}^{3 / 4}$

Dry matter in feed, grams: Sudan hay, 3,580 ; beet pulp, 400; casein, 90 ; barley, 4,183; total dry matter. 8,253 .

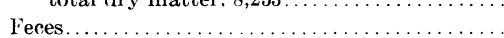

Digested nitrogen, carbon, or energy .......

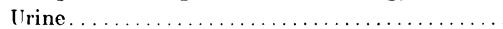

Methane (343 liters).

Metabolizable nitrogen, carbon, or energy . . .

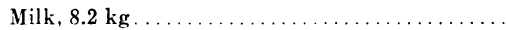

Katabolizable nitrogen, carbon, or energy . . .

Heat (respiration, 3,319 liters $\mathrm{CO}_{2}$ ) . . . . . . . .

Gain in body substance. . . . . . . . . . .

Gain in body protein ( $\mathrm{N}$ gain $\times 6.25)$.

Gain in body fat $(C$ in gained fat $\times 1.31)$.

\begin{tabular}{|c|c|c|c|c|c} 
& & & & & \\
176.8 & $\ldots$ & 3,641 & $\ldots \ldots$ & 35,870 & $\ldots \ldots$ \\
$\ldots$ & 66.0 & $\ldots \ldots$ & 968 & $\ldots \ldots$ & 9,770 \\
110.8 & $\ldots$ & 2,673 & $\ldots$ & 26,100 & $\ldots \ldots$ \\
$\ldots$ & 47.0 & $\ldots \ldots$ & 135 & $\ldots \ldots$ & $1,350^{\mathrm{a}}$ \\
$\ldots$ & $\ldots$ & $\ldots \ldots$ & $184^{\mathrm{b}}$ & $\ldots \ldots$ & $3,260^{\mathrm{c}}$ \\
63.8 & $\ldots$ & 2,354 & $\ldots \ldots$ & 21,490 & $\ldots \ldots$ \\
$\ldots$ & 52.1 & $\ldots \ldots$ & 695 & $\ldots \ldots$ & 7,850 \\
11.7 & $\ldots$ & 1,659 & $\ldots \ldots$ & 13,640 & $\ldots \ldots$ \\
$\ldots$ & $\ldots$ & $\ldots \ldots$ & $1,779^{\mathrm{d}}$ & $\ldots \ldots$ & $15,180^{\mathrm{k}}$ \\
11.7 & $\ldots$ & $\ldots \ldots$ & -120 & $\ldots \ldots$ & $-1,540^{\mathrm{i}}$ \\
11.7 & $\ldots$ & $38^{\mathrm{e}}$ & $\ldots \ldots$ & $420^{\mathrm{f}}$ & $\ldots \ldots$ \\
$\ldots$ & $\ldots$ & $\ldots \ldots$ & $-158 \mathrm{~s}$ & $\ldots \ldots$ & $-1,960^{\mathrm{h}}$ \\
\hline
\end{tabular}




\section{APPENDIX TABLE B}

\section{Summary of Results on Feed Utilization}

\section{Sudan Hay for Maintenance}

a. Protein in Sudan hay

Protein in 100 grams dry hay $(\mathrm{N} \times 6.25) \ldots \ldots \ldots \ldots \ldots \ldots \ldots \ldots \ldots \ldots \ldots \ldots \ldots \ldots .2 \mathrm{grams}$

Digestibility of nitrogen in hay ..........................

Digestible protein in 100 grams dry hay ................... grams

Net nitrogen per 100 grams total nitrogen ......................... $25 \pm 1$ grams

Net nitrogen per 100 grams digested nitrogen................. $41 \pm 2$ grams

Net nitrogen per 100 grams dry Sudan hay................... $0.53 \pm 0.03$ gram

b. Requirement for protein maintenance per day per unit of metabolic body size $\left(\mathrm{W}^{3 / 4}\right)$

Total nitrogen in Sudan hay....................... $0.70 \pm 0.03$ gram per kg ${ }^{3 / 4}$

Digested nitrogen in Sudan hay...................... $0.43 \pm 0.02$ gram per $\mathrm{kg}^{\mathrm{*} / \mathrm{k}}$

Dry Sudan hay................................... $33 \pm 2$ grams per kg ${ }^{3 / 4}$

Dry Sudan hay for protein maintenance of a 1,000 -pound cow per day . . . . 7.0 pounds c. Energy in Sudan hay

Heat of combustion in 100 grams Sudan hay...................... $423 \mathrm{kcal}$

Digestibility of energy in Sudan hay...................6. $67 \pm 0.4$ per cent

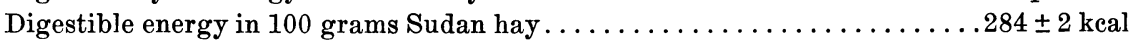

Metabolizability of digested energy ......................

Metabolizable energy per 100 grams dry Sudan hay.............222 \pm 1 keal

Net energy in digested energy of Sudan hay................. $59 \pm 2$ per cent

Net energy in metabolizable energy. ...................

Net energy in 100 grams dry Sudan hay.................... $167 \pm 6$ keal

d. Requirement for energy maintenance per day per unit of metabolic body size $\left(W^{3 / 4}\right)$

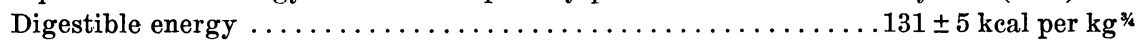

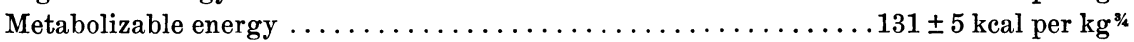

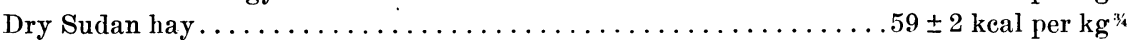

Dry Sudan hay for energy maintenance of a 1,000-pound dry cow per day. . . 13 pounds e. Methane production from Sudan hay

Methane produced per 100 grams dry Sudan hay $\ldots \ldots \ldots \ldots \ldots \ldots .70 \pm 0.07$ liters

Methane produced per 100 grams dry Sudan hay................ 2.640 .05 grams

Methane produced per 100 grams carbohydrates in Sudan hay....... $3.5 \pm 0.07$ grams

Methane produced per 100 grams digestible carbohydrates in Sudan hay $.4 .4 \pm 0.08$ grams

a. Protein in barley

\section{Barley for Lactation}

Protein in 100 grams dry barley.......................... $11.2 \pm 0.9$ grams

Partial digestibility of nitrogen in barley................... $72 \pm 4$ per cent

Partial digestible nitrogen in 100 grams dry barley............. $1.28 \pm 0.06$ grams

Partial net nitrogen in 100 grams dry barley.................. $0.96 \pm 0.24$ grams

b. Energy in barley

Heat of combustion in 100 grams of dry barley................. $438 \pm 3 \mathrm{kcal}$

Partial digestibility of energy in barley.......................

Partial digestible energy in 100 grams dry barley................. $339 \pm 6 \mathrm{kcal}$

Partial metabolizable energy in 100 grams dry barley...........293 \pm 10 kcal

Partial net energy in 100 grams dry barley.................. $194 \pm 25$ kcal

c. Methane production from barley

Partial methane production per 100 grams dry barley ............. $3.2 \pm 0.5$ grams

Partial methane production per 100 grams carbohydrates in barley . . . 3.8 \pm 0.6 grams 


\section{TABLE B (Concluded) \\ Casein for Lactation}

Total nitrogen in 100 grams dry casein (as used) $\ldots \ldots \ldots \ldots \ldots \ldots \ldots \ldots .2 \pm 0.6$ grams Partial digestibility of nitrogen in casein...................65 \pm 4 per cent Partial net nitrogen in 100 grams dry casein................ $10.7 \pm 0.6$ grams

\section{Glucose for Lactation}

Total energy in 100 grams dry glucose (value for pure glueose) . . . . . . 374 keal Partial digestibility of energy in glucose.................... $85 \pm 1$ per cent Partial digestible energy in 100 grams dry glucose................ $313 \pm 4$ keal Partial methane production from 100 grams glucose............ Partial metabolizable energy per 100 grams glucose.............283 \pm 5 keal Partial net energy per 100 grams glucose..................... $154 \pm 15$ kcal

APPENDIX TABLE C

Metabolic Body Size for Body Weight of Catple

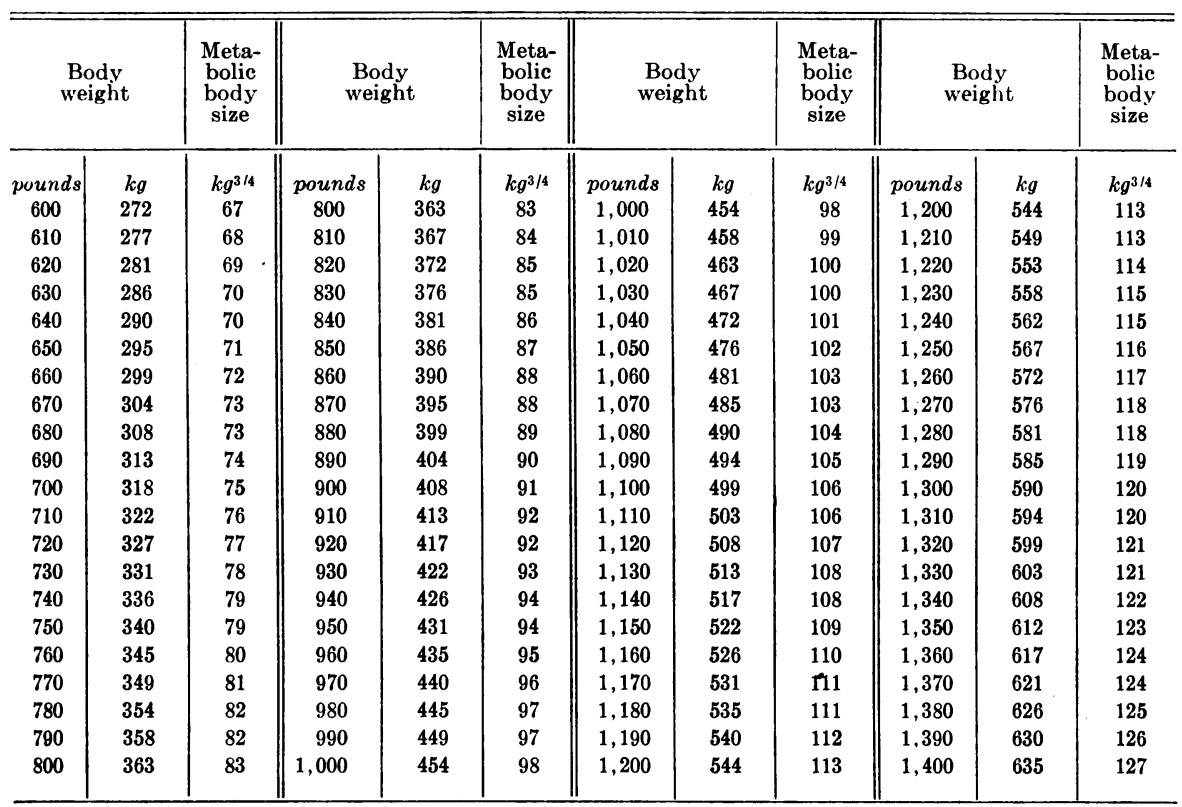

